Dedicado a José Brochado, usina de idéias.

Agradecimentos: a Walter Neves, pelo estímulo e pelas idéias que contribuiram para melhorar este texto. A Adriana S. Dias, Fabíola A. Silva e Jorge Eremites, pelos comentários e sugestões sempre petinentes. A José lópez Mazz, pela gentileza de ter enviado seu artigo de síntese, ainda no prelo, sobre as pesquisas na "cuenca" da lagoa Mirim, Uruguai. A Américo Marques e Aló́sio Karling, pela confecção das figuras. A Jane A. Trindade, pelos comentários apoio irrestrito. A interpretação e abordagem são de minha exclusiva responsabilidade.
FRANCISCO SILVA

\section{NOELLI}

Laboratório de

Arqueologia, Etnologia e

Etno-História

Universidade Estadual

de Maringá

E-mail:

ffnoelli@wnet.com.br

\title{
A OCUPAC̣̃̃O
}

HUMANA

NA REGIÃO SUL

DO BRASIL:

\section{ARQUEOLOGIA,}

\section{DEBATES}

\section{E PERSPECTIVAS}

\section{2-2000}




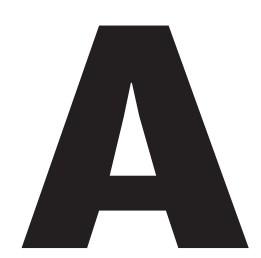

s pesquisas arqueológicas na Região Sul do Brasil (1) estão completando 128 anos. Seus estados, Rio Grande do Sul, Santa Catarina e Paraná (Figura 1), constituem as áreas brasileiras mais conhecidas arqueologicamente, com cerca de 3.500 sítios localizados, diversos conjuntos tecnológicos definidos e um quadro cronológico geral que inicia há cerca de 12.000 anos antes do presente (AP). Há 18 instituições de pesquisa, diversos museus, numerosas coleções arqueológicas, um curso de pós-graduação em arqueologia iniciado em 1991 (PUCRS, mestrado e doutorado) e uma das maiores concentrações de arqueólogos do país.

Se, por um lado, existe a possibilidade de encontrar ocupações humanas anteriores a 12.000 $A P$, por outro, há pouca probabilidade de se encontrar conjuntos de evidências materiais de populações distintas das conhecidas até agora. Neste momento em que se começa a sair de uma etapa "histórico-classificatória" (Willey e Sabloff 1980), as pesquisas se dirigem para o questionamento e refinamento dos esquemas interpretativos em voga, repensando-os e propondo outras problemáticas, em uma renovação que começou a germinar em meados dos anos 80 e que ganha cada vez mais força e espaço no presente.

Chegamos ao novo milênio com uma noção do que ainda não se sabe e do que é preciso fazer. $\bigcirc$
Este artigo não ana lisa o litoral Atlântico, uma vez que Tania Andrade Lima está cuidando dessa área.
FIGURA 1

REgIÃo SUL

DO BRASIL

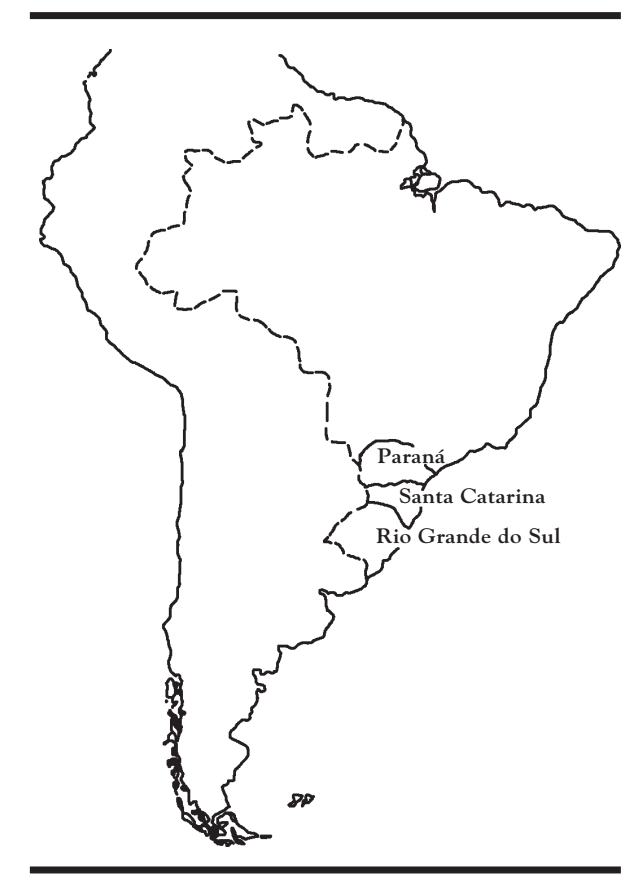


reconhecimento dos progressos da arqueologia internacional por uma parte da comunidade científica que pesquisa esta região trouxe a necessidade de olhar e pensar fora dos parâmetros estabelecidos na década de 60 , época dos primeiros passos da formação profissional (Dias 1995; Barreto 1998). Esta formação foi baseada em estágios de curta duração, com treinamento sobre técnicas de campo e laboratório, com pouca ou nenhuma ênfase em teoria arqueológica ou teorias afins. A formação pós-graduada da primeira geração ocorreu a partir da segunda metade dos anos 70, com a realização de estudos na PUC-RS, USP e exterior (França e Estados Unidos), mas não alterou a postura empirista, que seria questionada apenas pela terceira geração, formada no início dos 90.

Se o legado da maioria das pesquisas realizadas desde 1960 é uma enorme massa de dados ainda pouco analisados, existe, por outro lado, uma limitação empírica e teórica que impede a compreensão ampla das populações do Sul, em termos biológicos, sociológicos, históricos e econômicos. A base de dados conduz para um único caminho, povoado de informações obtidas a partir da localização de sítios arqueológicos, coletas assistemáticas de superfície, escavações de pequenas áreas, estratigrafia em níveis artificiais, classificações morfológicas, cronologias absolutas e relativas baseadas em seriações de fragmentos cerâmicos e uma interpretação que concebeu os sítios como unidades isoladas, despidas de interpretação sociológica e histórica. Considerando o padrão não-estatístico da maioria dos resultados de pesquisa, quase exclusivamente apoiados sobre os artefatos isolados, é possível dizer que a maioria dos dados da arqueologia do Sul está "muito longe de atender os requisitos de uma análise quantitativa de qualidade insuspeita", a exemplo da conclusão de Neves e Blum (1999:151) sobre a antropologia física no interior do CentroSul do Brasil.

De fato, a maioria dos dados arqueológicos conhecidos serve para concluir que: 1) houve ocupação humana; 2) que ela foi mapeada geográfica e cronologicamente; 3 ) que a datação mais antiga para o Sul alcança 12.000 AP; 4) que há uma distinção formal, estilística e tecnológica entre os principais conjuntos de registros arqueológicos; 5) que houve diversos processos de ocupação do espaço ao longo do tempo por populações distintas; 6) que há padrões de adaptação ecológica; 7) que há continuidade e coincidência entre grupos linguiísticos e cultura material. Porém, não há estudos de história local ou regional que enfoquem aspectos diversos, a exemplo de: 1) variabilidades demográficas ao longo do tempo; 2) sobre relações de poder; 3 ) organização espacial, social e política; 4) economia e comércio; 5) saúde e doença; 6) relações interétnicas; 7) outras temáticas de interesse arqueológico. Sabe-se pouco sobre as variabilidades e diferenças no interior destes grandes conjuntos, exceto quando há fontes escritas sobre as populações que têm relação de continuidade com as populações pré-históricas.

Estamos apenas começando a superaro padrão esquemático e lacunar de inspiração histórico-cultural “à brasileira” (2) que deu suporte à construção da arqueologia predominante no Sul do Brasil. Esta abordagem visou definir conjuntos a partir de registros materiais enquadrados nos vetores lugar e tempo, representados por indicadores e padrões morfológicos semelhantes. Geralmente as diferenças no interior destes conjuntos foram consideradas como: 1) intrusões devidas ao contato com populações de cultura material distinta; 2) adoção de objetos por difusão; 3) mudança devida a processos migratórios ou de difusão. Logo, as semelhanças foram usadas arbitrariamente como marcadores materiais que "atestavam" uniformidades passíveis de serem rastreadas no espaço e no tempo, cujos processos foram invariavelmente interpretados como fenômenos de difusão de traços culturais. Além disso, toda esta interpretação esteve integrada a uma abordagem que privilegiou a descrição superficial dos ambientes e o enquadramento dos vestígios em diferentes ecossistemas e relevos, vagamente definidos (Dias 1994, 1999). Conforme Lima (1997), isso proporcionou a disseminação de um padrão 
explicativo a partir de uma ecologia cultural "não raro equivocada, fornecendo mais propriamente cenários que discutindo de forma efetiva o fenômeno da mudança decorrente de adaptações dos sistemas socioculturais ao meio ambiente".

\section{OBJETIVO}

Este artigo propõe uma síntese sobre a ocupação humana do Sul do Brasil, destacando com maior ênfase problemas abertos à pesquisa ao invés de reiterar fatos e conclusões que já foram repetidos em trabalhos anteriores. O objetivoé estabelecer procedimentos distintos das interpretações que estabeleceram o atual conhecimento sobre a Região Sul, tentando escapar das explicações deterministas e difusionistas ainda em voga. Meu intento está de acordo com a estratégia desta coletânea, onde partimos do princípio de que é preciso superar as interpretações atuais, modificando a estrutura teórica, metodológica e prática, a exemplo do que é apresentado nos textos de W. Neves, P. P. Funari eÉ. González. Eles mostram que este processo de atualização não ocorre tranqüilamente, vindo carregado de acirrados debates em torno das posturas científicas consolidadas entre 1960 e 1980. Simultaneamente, eles questionam a política acadêmica conduzida por alguns grupos que impuseram, nas últimas quatro décadas, um modelo monolítico de pesquisa, impedindo o livre trânsito das idéias, métodos e informações sobre o estado da arqueologia no resto do mundo, bem como estabeleceram a prática de ignorar idéias e pesquisas relevantes que lhes fossem dissonantes, mesmo que reconhecidas em outros meios. Ou seja, no Sul do Brasil se fez basicamente um tipo de pesquisa até o início dos anos 90, com a padronização dos métodos e da apresentação dos resultados, seguindo o padrão estabelecido por Betty Meggers e Clifford Evans, mentores e principais patrocinadores das pesquisas realizadas entre 1965-70 no Programa Nacional de Pesquisas Arqueológicas (Pronapa 1970) e, posteriormente, através de subsídios e apoio a diversas pesquisas e instituições. Quem não concordava, por razões de ordem teóricometodológica, era obrigado a desistir da carreira de arqueólogo ou lecionar outras disciplinas e constituir grupos marginais, sem acesso aos financiamentos das instituições de fomento científico e às publicações, ambos nas mãos dos grupos que dominaram a arqueologia no Brasil.

Esse padrão foi unilateral, fechado a abordagens distintas, comprimindo artificialmente as evidências, ignorando os contextos arqueológicos, escapando de inferências sociológicas e antropológicas historicamente definidas, bem como reduzindo a possibilidade de detectar as variabilidades e as particularidades da história de cada grupo local. Pelo intermédio deles proliferou uma abordagem conduzida sob uma versão empobrecida e distorcida dos determinismos históricos e ecológicos, do difusionismo e do evolucionismo. O domínio das idéias e práticas propostas por Meggers e Evans foi facilitado pelo despreparo científico e pela carência de suporte institucional-financeiro dos jovens arqueólogos treinados por eles há 35 anos. Isso levou Trigger (1989) a qualificar Meggers, devido as suas proposições, como autêntica representante das "idéias evolucionistas do século XIX”. Outros analistas mais críticos entenderam que eles pontificaram com "procedimentos pseudocientíficos" (Brochado 1984:29), "obscurantismo acadêmico" (Roosevelt 1995) e "positivismo ingênuo" (Funari 1989, 1991). Roosevelt(1991b:105), refletindo sobre a história da arqueologia na Amazônia, concluiu que Meggers e Evans conseguiram impor uma prática "feudal de longa duração”. Isso pode ser estendido para o Sul do Brasil, uma vez que seus associados meridionais reproduziram ortodoxamente seus atos e suas idéias e métodos.

\section{SUMÁRIO DA HISTÓRIA DA ARQUEOLOGIA NO SUL DO BRASIL}

Os resultados gerais referidos neste texto decorrem da própria realidade da disciplina na região, que passou a maior parte 
dos seus 128 anos atuando de forma amadora e ocasional, cuja história pode ser dividida em duas fases. Uma eminentemente exploratória e colecionista, feita por amadores ou profissionais estrangeiros a partir de 1872, ano da primeira publicação com fim arqueológico, até 1954. Esse ano foi marcado pela fundação de uma seção de arqueologia na Universidade do Paraná e pela dotação do cargo de arqueólogo em tempo integral. Esta segunda fase desenvolve-se até o presente, com a fundação de várias instituições de pesquisa, formação de pesquisadores e diversificação das áreas de trabalho arqueológico.

Ainda não sabemos os detalhes da história da arqueologia no Sul, como ela foi sendo constituída, quais os contextos sociológicos, intelectuais e políticos relacionados, especialmente para a primeira fase. A segunda fase vem sendo analisada por Funari (1994, 1995), que tem estudado a constituição do grupo vinculado a Meggers e Evans e o período em que eles dominaram o campo científico no Brasil. A primeira fase iniciou-se em um ambiente científico e social do final do século XIX, marcada por idéias adaptadas do evolucionismo e do darwinismo social que pregavam a inferioridade dos povos indígenas e justificavam as práticas colonialistas de dominação e expropriação de seus territórios (Schwarcz 1993; Mota 1998). Infelizmente ainda dependemos de uma pesquisa nas publicações e arquivos das instituições para termos a exata medida do que se pensava e pretendia.

As principais linhas de pesquisa foram:

1) verificar se os sambaquis eram naturais ou artificiais (1876-1930);

2) definir o conteúdo de sítios litorâneos (1930-50);

3) estabelecer a relação dos sambaquis com as variações do nível do mar (1945-50);

4) conhecer o conteúdo dos sambaquis (1950-70);

5) mapear e datar as rotas de migração de povos ceramistas para o Sul do Brasil (1965-70);

6) definir conjuntos materiais e as tradições arqueológicas (1968-77);
7) realizar sínteses sobre as ocupações préceramistas e ceramistas (1977-84);

8) fazer estudos métricos e não-métricos em esqueletos do litoral de SC e PR (desde 1955);

9) repensar os resultados e introdução de novas teorias e métodos (anos 90).

As linhas gerais de pesquisa foram poucas, como se pode ver, e, na maioria dos casos, com problemáticas derivadas de modelos construídos para resolver questões de outras partes do Brasil ou de outros países. Simplesmente, os indígenas do Sul do Brasil, sua cultura e sua história não foram alvo dos arqueólogos. A prática de ignorar as populações indígenas em relação à arqueologia não foi inaugurada por Meggers e Evans, mas apenas consolidada por eles, em procedimento repetido desde as primeiras publicações, em que os dados indígenas serviam para subsidiar alguma especulação ou para ratificar os preconceitos em relação aos alcunhados como "bugres", "primitivos", "atrasados", etc.

A arqueologia profissional no Sul foi conduzida a partir de um pressuposto sugerido nos anos 50 por Meggers (1955:129): "tratar a cultura de uma maneira artificialmente separada dos seres humanos". A adoção desse princípio justificou uma interpretação hermética e refratária em relação às idéias e fatos do panorama americanista, instrumentalizando uma estratégia de seleção de dados que ignorou a maioria das informações históricas, lingüísticas e etnográficas preexistentes, assim como os resultados de pesquisadores movidos por outras idéias, como ocorre até hoje. Sua aplicação resultou em modelos e hipóteses simplistas, estanques em relação às que estavam sendo desenvolvidas por outras disciplinas, dissociando a pesquisa arqueológica da antropologia e das outras ciências sociais que floresciam no Brasil desde o século XIX.

Isso não foi privilégio da arqueologia, uma vez que no Sul do Brasil também são raros os estudos etnográficos com objetivo de realizar monografias nos moldes "clássicos". Até hoje poucos pesquisadores, a exemplo de Santos (1973), Urban (1978), 
Tommasino (1995) e Mota (1994, 1998), refletiram sobre processo histórico, e só recentemente surgiu uma nova geração que abandonou interpretações ingênuas ou mecânicas, que tradicionalmente desconsideraram os problemas derivados dos contatos, ignorando as inúmeras guerras travadas entre índios e brancos, as epidemias que facilitaram a instalação dos brancos, a formação da sociedade nacional, o impacto ecológico da economia européia e os processos que acabaram em genocídio e na opressão dos povos indígenas que sobreviveram no espaço que virou Brasil. Nesse sentido, serve o exemplo legado por Mota (1994a, 1994b), que mostrou como os historiadores paranaenses construíram uma interpretação que simplesmente desconsiderou os povos indígenas, inventando a idéia de um vazio demográfico naquele estado.

Ao invés de verificar as evidentes relações de continuidade entre os povos indígenas e os registros arqueológicos, os pesquisadores optaram por criar um ambiente totalmente estanque e artificial, construindo a história e a cultura dessas populações a partir de seus próprios pressupostos, invariavelmente ignorando fontes históricas e etnográficas. Esse padrão continuou mesmo depois dos anos 60, quando a arqueologia internacional se reaproximou definitivamente da etnologia e da história, de forma que muitos arqueólogos do Sul do Brasil ainda não conseguiram demonstrar o uso de categorias analíticas e interpretativas a partir de uma "realidade" derivada da própria história e cultura dos povos indígenas.

A geração que se profissionalizou nos anos 60, formada apenas para desempenhar tarefas técnicas, como coletar e analisar amostras, adotou sem questionar os esquemas interpretativos modelados por Meggers e Evans a partir das idéias originais de pesquisadores do século XIX, início do século $\mathrm{XX}$ e do determinismo ecológico na Amazônia. Como já especifiquei em outros artigos (Noelli 1996a, 1998, 1999), os então "novos arqueólogos" do Sul abraçaram esquemas de trabalho sem conhecer fundamentos científicos elementares, ignorando a história do desenvolvimento da arqueologia internacional, bem como da antropologia brasileira e americanista. Dessa maneira, o desconhecimento da história das pesquisas e idéias levou-os a reproduzir acriticamente interpretações e modelos despidos de qualquer base arqueológica originalmente propostos por von Martius (1867), Ehrenreich (1891), von den Steinen (1894), Nimuendajú ([1914] 1987), sintetizados posteriormente por Métraux (1928). Nos anos 50 e 60 esses modelos foram indevidamente apropriados por Meggers e Evans, que só os citariam na década de 70. Foi deles que o casal extraiu a idéia para suas "rotas de difusão da cerâmica". Assim, os dados arqueológicos, à medida que eram obtidos a partir da década de 60 , eram simplesmente encaixados no modelo de Métraux, sempre imaginados como "migrações", sem nenhuma preocupação em investigar aspectos históricos, sociológicos, antropológicos ou biológicos (Noelli 1996a).

Diversos pesquisadores têm demonstrado como foi montado este campo científico no Brasil e os problemas derivados da falta de debate a partir dos avanços teóricometodológicos da arqueologia internacional e da carência de interpretações despidas de erudição etnográfica, que vigoram até hoje graças à estrutura acadêmica montada e dominada por certos grupos (Neves 1988, 1989; Roosevelt 1991a; Funari 1991, 1994, 1999; Noelli 1996b, 1999; Dias 1995; Viveiros de Castro 1996; Neves 1995, 1998). Destacam-se os (pré)conceitos deterministas ecológicos relativos à baixa complexidade sociológica, política e econômica dos povos indígenas; baixa densidade demográfica; dependência das ofertas/restrições da natureza; baixo nível de adaptabilidade ecológica, etc. Esses preconceitos, forjados para a Amazônia sem base de dados, também foram generalizados para o Sul, como se não houvesse diferenças históricas, culturais e ambientais. Podemos dizer que, de fato, o arsenal de idéias dos anos 60 refletiu muito mais a limitação do método pronapiano, os problemas de pesquisa estabelecidos por Meggers e Evans e o preconceito etnocên- 
trico em relação aos indígenas, do que inferências a partir dos registros arqueológicos conhecidos. Também houve uma forte carga de prepotência ao não se praticar o exercício de submeter métodos e resultados ao constante debate e crítica.

\section{FONTES DE PESQUISA}

Os problemas teórico-metodológicos expostos interferem diretamente na construção de uma síntese sobre a ocupação humana do Sul do Brasil. Os dados arqueológicos não permitem explanações detalhadas e modos consistentes de expor didaticamente os mais diversos aspectos das populações pré-históricas do Sul, tendo em vista um público heterogêneo, não iniciado na linguagem própria do meio acadêmico. Portanto, não escaparei das generalizações quando tratar de algumas populações, assim como recorrerei sistematicamente aos dados históricos quando tratar de outras, especialmente das Guarani e Jê do Sul. Por outro lado, evitarei reproduzir os mesmos recursos explicativos de outras sínteses sobre o Sul, quase todas voltadas para aspectos ambientais e/ou tecnológicos e morfológicos das evidências encontradas. Também não farei uma “maquiagem” utilizando o jargão e a interpretação processualista, uma vez que os resultados publicados não derivam da arqueologia processual.

Nesse sentido, cabe indicar leituras básicas e alternativas aos interessados na arqueologia do SuldoBrasil. Como se pode ver na Figura 2, houve um aumento na quantidade de publicações sobre arqueologia do Sul do Brasil a partir da década de 60 , chegando a uma regularidade em torno de 175 títulos nas décadas de 60, 70 e 80 . Na década de 90, devido ao aumento de pesquisadores egressos da pós-graduação, a produção passou para 314 títulos (até agosto de 1999). Atualmente existem cerca de 1.000 títulos sobre o Sul, com a maioria arrolada na Bibliografia da arqueologia brasileira (Kipnis et al. 1994-95). Também deve-se consultar os guias bibliográficos de história, etnologia, lingüística e outras disciplinas científicas sobre os povos indígenas do Sul do Brasil: Guarani: uma bibliografia etnológica (Melià, Saul e Muraro 1987) e Guaraníes y jesuítas en tiempo de misiones (Melià e Nagel 1995), com cerca de 2.000 títulos sobre os Guarani; Bibliografia Kaingang: referências sobre um povo Jêdo Sul (Noelli et al. 1998), com 1.100 títulos sobre os Kaingang. Sobre os Xokleng existem aproximadamente 600 títulos, com a lista bibliográfica ainda em fase de elaboração (Tommasino et al. s.d.). A respeito dos Xetá há uma reduzida produção, com menos de 80 títulos disponíveis (Silva 1998). Sobre os Charrua e Minuano também há poucas publicações, a maioria em arqueologia, com aproximadamente 400 títulos (Becker 1983; Hilbert 1991). Considerando o recorte geográfico deste trabalho, nãoincluí populações de áreas fronteiriças, como os Tupiniquim, Oti, AchéGuayakí, Payaguá, Guaykuru e vários povos do médio-baixo Rio Paraná, como se pode ver no Mapa Etno-histórico de Curt Nimuendajú (1981). O livro Línguas brasileiras (Rodrigues 1986) apresenta o panorama lingüístico, as línguas faladas e suas relações com povos de fora do Sul.

Entre as sínteses arqueológicas sobre o Sul do Brasil, destacam-se duas teses de doutorado, por conterem e tratarem extensamente da massa principal de dados publicados até 1983 e, que ainda não foram suplantadas, em seus termos mais gerais. Uma trata de populações “pré-ceramistas”, usando estudos realizados entre 1959 e 1981 , intitulada Le précéramique du plateau SudBrésilien (3). A outra analisa populações "ceramistas", com estudos publicados de 1876 a 1983, intitulada Anecological model of the spread of pottery and agriculture into Eastern South America (4).

Um dos maiores problemas da atualidade é a desigualdade na qualidade e quantidade e nos objetivos das publicações para cada um dos estados do Sul. No Paraná predominam os relatórios de levantamentos regionais, que deram conta de quase todo o espaço do estado. Porém, há uma escassez de interpretações decorrente da crônica falta de arqueólogos e da excessiva 
FIGURA 2

\section{Periodicidade das publicações sobre arqueologia do Sul do Brasil}

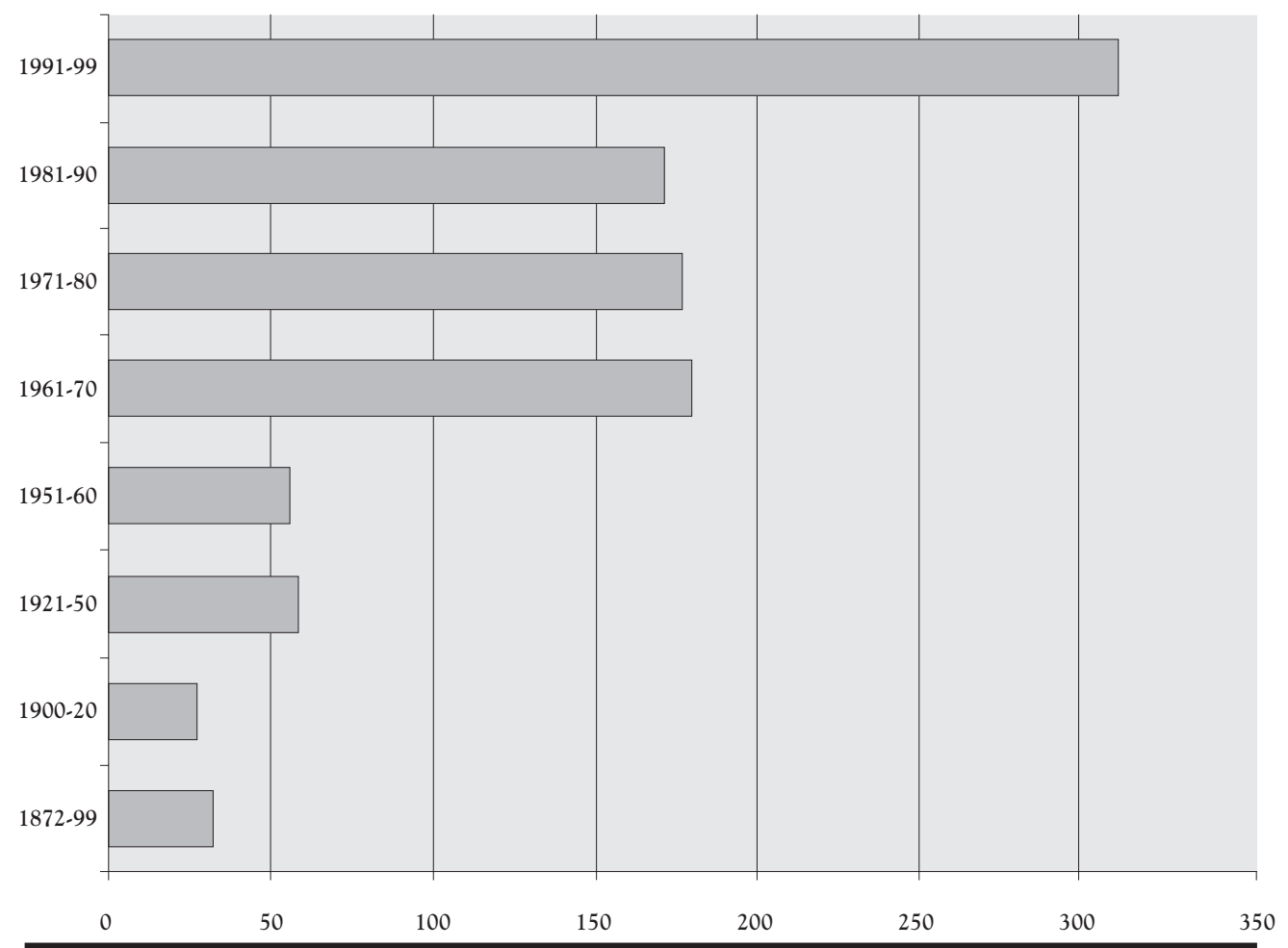

centralização sobre certas instituições e personagens. Além disso, entre os anos 70 e o final dos 90, as pesquisas no Paraná resumiram-se praticamente à "arqueologia de contrato", em detrimento de trabalhos motivados por problemas científicos e da formação de novos pesquisadores. Em Santa Catarina as pesquisas são majoritárias no litoral, predominando o estudo de sambaquis e de arqueologia histórica (em função da restauração de alguns fortes e outras edificações coloniais). No interior as pesquisas foram intensas entre os anos 60 e o início dos 80 , mas acabou restrita a amostragens preliminares. No presente a comunidade de pesquisadores catarinenses está crescendo, com a formação pós-graduada de novos arqueólogos que contribuem com problemáticas e interesses renovados. O Rio Grande do Sul se destaca, desde os anos 60, pelo número maior de pesquisadores, conseqüentemente uma produti- vidade mais intensa, bem como a preocupação em formar novos profissionais, a exemplo da constituição do curso de pósgraduação em arqueologia. Todas as suas áreas foram prospectadas até o final dos anos 70 e houve sempre a preocupação em realizar sínteses e interpretações, indo além dos restritos relatórios.

Existem trabalhos cujo objetivo é a síntese regional ou análise de casos específicos, com resultados, discussões e críticas importantes sobre os modelos vigentes, trazendo novos aportes à compreensão de diversos aspectos das populações préceramistas. Hoeltz (1997) e Dias (1994) representam as melhores análises e discussões sobre os elementos materiais e tecnológicos que definem as tradições Umbu e Humaitá. Milder (1994, 1995, 1999) discutiu as pesquisas realizadas e analisou aspectos sobre as ocupações mais antigas, há cerca de $12.000 \mathrm{AP}$, do período 
“paleoindígena”. Há sínteses com enfoques histórico-culturalista e difusionista (Schmitz 1987, 1991, 1999), que divulgam as interpretações com abundantes dados sobre geografia, ambientes e registros arqueológicos, e outros que apresentam aspectos regionais dessas populações (Ribeiro 1991, 1995, 1999a). Há trabalhos de antropologia física, com novos resultados, discutindo o estado da questão no Sul (Neves 1984; Cocivolo e Neves 1988-89; Neves e Blum 1999), bem como sobre a subsistência de grupos sambaquianos (Bandeira 1992), oficinas líticas (Amaral 1995) e a retomada de antigas pesquisas (Silva 1988; Masi 1990).

Sobre as populações "ceramistas" há trabalhos de mestrado que trazem novas abordagens e reflexões, como o estudo sobre habitações semi-subterrâneas dos povos Jê (Reis 1980; Reis 1997), organização social e arqueologia Guarani (Soares 1997; Noelli e Soares 1997a, 1997b), relação com o espaço e adaptabilidade Guarani, e cultura material (Noelli 1993; 1996a; Noelli e Dias 1995; Noelli, Trindade e Simão 1999; Brochadoe Noelli 1998). Algumas pesquisas introduziram estudos de gênero (Landa 1995), dieta (Landa e Noelli 1997), etno-história (Lavina 1994), etnoarqueologia (Monticelli 1995; Garlet e Soares 1998) e a discussão de algumas teorias adaptacionistas da Amazônia aplicadas ao Rio Grande do Sul (Rogge 1996). Há trabalhos sobre a história da pesquisa do povoamento do Sul, que discutem os problemas do desenvolvimento da pesquisa (Noelli 1996a, 1998, 1999; Silva e Noelli 1996a, 1996b). Há pesquisas sobre práticas funerárias (Montardo 1995; Montardo e Noelli 1996) e sínteses gerais que apresentam as evidências por tradição arqueológica (Schmitz 1988; Kern (org.) 1991d).

A produção em arqueologia histórica data dos anos 80 e cresce substancialmente, com diversas pesquisas em assentamentos coloniais, imperiais e republicanos no Sul do Brasil (Jacobus 1998). A maioria das pesquisas tem privilegiado o espaço e a cultura material, dando pouca ênfase à etnicidade, ao racismo, ao gênero e à opressão (Funari 1997), estando ainda em com- passo de espera os estudos que consigam fazer emergir sujeitos, tais como os "indígenas", os "escravos" e os "pobres". Destacam-se as pesquisas feitas em cidades espanholas e missões jesuíticas do Rio Grande do Sul e Paraná, onde foram levantados planos urbanos dos séculos XVI e XVII. Estudam-se caminhos de tropeiros, pedágios, postos militares, fortes coloniais, engenhos de farinha, etc. Além disso, há um crescente desenvolvimento de arqueologia urbana em Porto Alegre. Porfim, também iniciaram estudos sobre processos de musealização (Tamanini 1995).

É importante mencionar que há estudos sobre as populações da Região Sul que ocuparam áreas vizinhas em São Paulo, Uruguai, Paraguai e as províncias argentinas de Misiones e Entre Ríos. O Paraguai é pouco conhecido e as províncias argentinas apresentam resultados que mostram relações com as populações do Sul do Brasil. São Paulo, nas bacias dos rios Paranapanema e bacia da Ribeira do Iguape, bem como no litoral, apresentam resultados que mostram as relações entre as populações nas "fronteiras" setentrionais da Região Sul. O Uruguai é a área contígua mais bem pesquisada, com seu território conhecido na maior parte, estando num estágio científico mais avançado que o do Sul do Brasil.

\section{A OCUPAÇ̃O HUMANA DO SUL DO BRASIL}

As pesquisas arqueológicas revelaram que a Região Sul foi ocupada em todos os seus espaços, configurados por relevos, ecótonos e climas diversificados que proporcionaram diversos tipos de adaptação ecológica. Não existe nenhum tipo de ambiente no Sul que não tenha sido ocupado sistemática ou ocasionalmente.

Há registros arqueológicos que formam conjuntos distintos entre si, definidos como "tradição" pelos arqueólogos e que representam diversas populações. São conhecidas apenas as linhas gerais de cada conjun- 
to, faltando indicadores de variabilidade que apontem para distintas etnicidades e outros diferenciadores de natureza biológica, lingüística, histórica, sociológica e antropológica. Para Consens (1999), isso resulta da condução simplista, determinista e unilateral das pesquisas, que ainda não distinguiu diferenças no interior das "tradições". Consens insiste que é preciso analisar os dados a partir de perspectivas mais amplas e cuidadosas, evitando as usuais na arqueologia do Sul do Brasil.

Embora a argumentação abaixo se utilize das semelhanças para definir cada uma das tradições, deve ficar claro que é uma estratégia que visa articular didaticamente os dados disponíveis, considerando que já apresentei uma posição crítica e revisionista em relação ao que foi estabelecido anteriormente. A exemplo de outros trabalhos (Noelli 1996a, 1996c, 1998, 1999a; Silvae Noelli 1996b), analisei o que está estabelecido, discutindo e sintetizando idéias e fatos obtidos independentemente pela arqueologia, pela antropologia, pela lingüística e pela história. Deve-se reconhecer, como já escrevi (Noelli 1996b), que os problemas ainda estão sendo definidos, que se busca delimitar o que não se sabe e, principalmente, que é preciso verificar as diferenças no interior das tradições.

Um aspecto a ser mencionado sobre a Região Sul, apesar dos problemas apontados acima, é a longevidade das tradições, como se constata nas áreas adequadamente pesquisadas e datadas. De fato, as tradições ainda não apresentaram variabilidades materiais significativas, contribuindo para a conclusão preliminar de que pelo menos a cultura material manteve uma padronização reproduzida constantemente, mesmo que tivessem ocorrido mudanças em outros níveis socioculturais. Observando área por área, não há mudanças notáveis no interior de cada tradição, motivadas por inovações locais ou adoções de novas técnicas através de contato interétnico (ver Tradição Vieira adiante, talvez a única exceção).

As mudanças verificadas no registro arqueológico e nas sequiências estratigráficas representam a presença de novas populações que colonizaram a Região Sul. O grande desafio no futuro será explicar os processos de colonização realizados pelos povos que vieram de fora da Região Sul e, paralelamente, como estes processos ocorreram regionalmente, caso a caso, e se há modificações no interior da tradição que possam ser explicadas.

As populações que começaram a conquistar o Sul do Brasil há cerca de 2.500 2.000 AP tinham estrutura, tecnologia, adaptabilidade e densidade demográfica distintas dos caçadores-coletores que viviam ali há cerca de 10.000 anos ou mais. Essas populações implantaram e reproduziram seus sistemas adaptativos baseados na agricultura e, paralelamente, incorporaram as novidades vegetais e animais do Sul, úteis para alimentação, medicina e elaboração de cultura material. Esses povos conquistadores formavam unidades politicamente aliadas em nível regional, com dimensões variáveis conforme o número de unidades locais e suas densidades demográficas. Eles trocavam sistematicamente informações e pessoas, contribuindo para a manutenção e reprodução constante da sua cultura material, da língua, etc. Assimilavam pessoas de outras etnias, impondo-lhes seus comportamentos, língua e sistemas tecnológicos, o que também contribuía para a reprodução de aspectos culturais. Ou seja, deve-se buscar uma explicação antropológica e arqueológica que considere populações que mantiveram baixos índices de variabilidade material, possivelmente explicados por uma prescritividade que regia suas sociedades.

Grosso modo, houve três levas humanas principais de ocupação que se expandiam a partir de regiões distintas. A primeira leva ocupou o Sul a partir de 12.000 ou 13.000 AP e parece ter se mantido estável, mantendo as mesmas características materiais, reproduzindo certos comportamentos adaptativos e econômicos de povos “caçadores-coletores", até cerca de 2.500 AP. Os registros arqueológicos dessas populações são chamados como Tradição Umbu e Tradição Humaitá, e os estudos 
quantitativos mais recentes de suas indústrias líticas têm revelado uma notável estabilidade no sistema tecnológico e na escolha das matérias-primas por parte dessas populações. Isso torna possível pensar na possibilidade de que alguns aspectos sociológicos, como a organização social e as formas de ocupação do espaço, tenham sido reproduzidos mantendo mais ou menos um padrão constante durante este longo período. Até que se tenham informações regionais detalhadas sobre densidade demográfica, padrões de fluxo gênico, padrões de abastecimento, indicadores de saúde/doença, variabilidade entre as indústrias líticas e outros marcadores arqueológicos, não haverá condições de se mostrar com consistência as diferenças no interior dessas tradições. Ainda não há indicadores que definam de qual região da América do Sul vieram essas primeiras populações, assim como ainda não sabemos qual ou quais foram as áreas de entrada para a região do Sul do Brasil.

É possível que essa primeira leva seja representante de grupos não-mongolóides pertencentes à “quarta migração”, que vem sendo proposta por Walter Neves e colegas (Neves et al. 1996; Neves e Blum 1999; Munford et al. 1995). Esse modelo, ainda em análise, aponta convincentemente para a ocupação inicial da América do Sul por populações não-mongolóides, representadas por grupos de paleoíndios, mais antigos e com registros arqueológicos distintos das populações mongolóides.

A aparente estabilidade das populações Umbu e Humaitá começou a ser alterada pela invasão de duas levas principais de populações “ceramistas", agricultoras, de matriz cultural distinta, Tupi e Macro-Jê, por volta de 2.500 anos atrás, respectivamente originárias da Amazônia e do Centro-Oeste do Brasil. Elas trouxeram consigo modelos de organização sociopolítica e economia baseada no manejo agroflorestal e de adaptabilidade, distintos das populações pré-ceramistas que viviam no Sul. Como se pode inferir dos registros arqueológicos regionais, essas populações tinham uma capacidade de reprodução biológica e cultural tais que em cerca de 1.000 anos dominaram as margens das principais bacias hidrográficas, expulsando, assimilando ou exterminando as populações que ali viveram por cerca de 10.000 anos.

A interpretação mais convincente até agora para explicar por que essas duas últimas levas populacionais Jê e Tupi teriam vindo para o Sul e se espalhado de maneira tão extraordinária foi proposta por Lathrap (1970, 1977) e Brochado (1984; Brochado e Lathrap 1982). Eles advogam a hipótese de que um grande crescimento demográfico na Amazônia, devido ao suporte dado pelo desenvolvimento da agricultura e de inovações tecnológicas associadas à alimentação, teria pressionado sucessivas levas humanas para fora da região amazônica. Todavia, ainda sabemos muito pouco sobre a temporalidade, a dinâmica e a complexidade desses movimentos, que envolvem variáveis ainda desconhecidas e que devem ser analisadas fora da perspectiva difusionista: 1) como os tipos de contato interétnico e ajustamentos regionais que podem incluir a expulsão de populações prévias, a assimilação de membros de populações prévias (mulheres e crianças), a fusão de sociedades distintas, a escravidão ou o genocídio; 2) a adaptabilidade aos novos ecótonos, climas e às suas floras e faunas, incluindo a dispersão fitogeográfica de espécies de uma região a outra; 3 ) troca de conhecimentos e componentes tecnológicos e estilísticos em função de adaptações regionais, fusões de populações distintas ou por razões estéticas; 4) coeficientes regionais e locais de fluxo gênico entre populações distintas; 5) padrões de crescimento demográfico e desdobramento/formação de novos grupos relacionados à ocupação do espaço.

Os marcadores que distinguem todas as populações do Sul são três, que podem ser empregados de forma isolada ou combinada : 1) lingüísticos; 2) materiais; 3) biológicos.

Os dados lingüísticos estão restritos aos Guarani, Xetá, Kaingang e Xokleng. A(s) língua(s) dos Charrua, Minuano, Bohanes e Yarós não foram estudadas, impossibilitando relações comparativas, e ainda fal- 
tam dados que comprovem continuidade biológica com as populações pré-históricas, impedindo interpretações consistentes. Os lingüistas demonstraram que as línguas Guarani e Xetá pertencem ao tronco lingüístico Tupi, cuja maioria dos falantes está situada na porção meridional do sudoeste amazônico (Rodrigues 1964, 1985). As línguas Kaingang e Xokleng pertencem ao tronco Macro-Jê, originário do CentroOeste do Brasil (Davis 1964, 1966). O processo de formação dos troncos lingüísticos e da derivação lingüística que resultou nas línguas historicamente conhecidas no Sul do Brasil, coincidindo com os registros arqueológicos, e que permite uma visualização didática da expansão geográfica dos Kaingang, Xokleng, Xetá e Guarani foi apresentada por Urban (1992).

Os dados arqueológicos, históricos e etnográficos, isolados ou em conjunto, definem as características materiais que marcam os conjuntos de cada uma dessas populações. A diferença entre os Guarani e os Kaingang/Xokleng é definida tanto em termos materiais quanto em termos lingüísticos, sociológicos e antropológicos (Davis 1966, 1968; Hicks 1966, 1971). Entre os Kaingang e Xokleng ainda não foi reconhecida distinção nos registros arqueológicos, que são semelhantes, mas existem claras diferenças lingüísticas, sociológicas, biológicas e materiais etnográficas entre esses dois povos Jê. Os Xetá se distinguem dos Guarani em termos materiais e sociológicos, mas possuem uma afinidade lingüística que os situa no mesmo grupo linguiístico. As populações das tradições Umbu e Humaitá possuem diferenças materiais e de posicionamento geográfico sutis entre si e, quando corretamente contextualizadas, suas evidências se distinguem das encontradas nos registros arqueológicos dos Guarani, Kaingang, Xokleng e Xetá. Quando incorretamente contextualizadas e quando não são datadas, os vestígios Humaitá se confundem com os artefatos líticos e resíduos de lascamento dos sítios-oficina Guarani.

Os dados biológicos distinguem as populações a partir de evidências métricas e não-métricas, obtidas em estudos de esqueletos, amostras de sangue e análise genética. As análises genéticas e esqueletais de populações do interior ainda estão por ser feitas em toda a Região Sul. Apenas os esqueletos do litoral foram estudados por Neves (1984; Neves e Blum 1999), que verificou que populações ascendentes dos Jê do Sul chegaram tardiamente ao litoral e que eram distintas das que já viviam na costa. As análises de Salzano e Sutton (1965; Salzano e Callegari-Jacques 1988) sobre haptoglobinas revelaram que os Kaingang e Xokleng possuem uma ancestralidade biológica comum, apesar das divergências significativas ocorridas durante o tempo que eles estão separados. Isso coincide com as conclusões lingüísticas de Wiesseman (1978), que demonstrou que suas línguas estão separadas há muito tempo, a partir da separação da família Jê. Os Kaingang e os Xokleng, por sua vez, também são biologicamente distintos dos Guarani históricos (Salzano e Sutton 1965). Sobre as tradições Umbu e Humaitá ainda não existem dados biológicos, tampouco sobre os ascendentes pré-históricos dos Guarani e dos Xetá.

As adaptações dessas populações foram pouco estudadas, ainda baseadas na idéia da caça como base das atividades de forrageio das tradições Umbu e Humaitá, em detrimento de estudos que procurem identificar índices de alimentação com vegetais. Isso decorre das técnicas pouco desenvolvidas de escavação e da falta de aplicação de outros meios de recolher amostras de restos vegetais, como a flotação, relegados a um segundo plano devido à eleição de problemas exclusivamente voltados aos vestígios líticos e cerâmicos.

É muito provável que as populações das tradições Umbu e Humaitá realizassem alguma modalidade de manejo ambiental, cultivando espécies úteis como alimento, medicina e fonte de matéria-prima, apesar de ainda não haver nenhuma informação a respeito. A exemplo de outras populações caçadoras-coletoras (Lee 1968; Hill et al. 1995; Politis 1996), eles também deveriam ter uma dieta provida por uma porcenta- 
gem significativa de vegetais e possivelmente contribuíram para a dispersão de várias espécies alimentícias a partir de 10.000 AP. Devem ter contribuído, por exemplo, para dispersão de palmeiras, como as do gênero Bactris, de origem amazônica (Brücher 1988), assim como é muito provável que tenham manejado as araucárias (Araucaria angustifolia), contribuindo para ampliar sua dispersão em diversos pontos da Região Sul do Brasil. É possível que as diversas comunidades vegetais em que predomina uma espécie sejam "florestas antropogênicas" ou "matas culturais" (Balée 1988, 1994; Noelli 1999b), como certas áreas de pinheirais, mas sobretudo os palmitais, butiazais e ervais, resultando de contínuos manejos ao longo da ocupação humana do Sul. Embora seja provável que várias espécies tenham sido cultivadas e manejadas pelas populações das tradições Umbu e Humaitá antes de 2.500-3.000 AP, foi com as populações Kaingang, Xokleng e Guarani que esta prática ficou visível aos nossos olhos. Pertencendo a agrupamentos culturais que se caracterizam por dominar diversas técnicas de manejo agroflorestal, essas populações contribuíram para enriquecer o patrimônio genético do Sul, trazendo consigo diversas espécies adotadas, desenvolvidas e aperfeiçoadas na Amazônia, Andes e América Central.

\section{FIGURA 3}

\section{Área da Tradição Umbu E REPRESEnTAÇão}

\section{DOS PONTOS DATADOS}

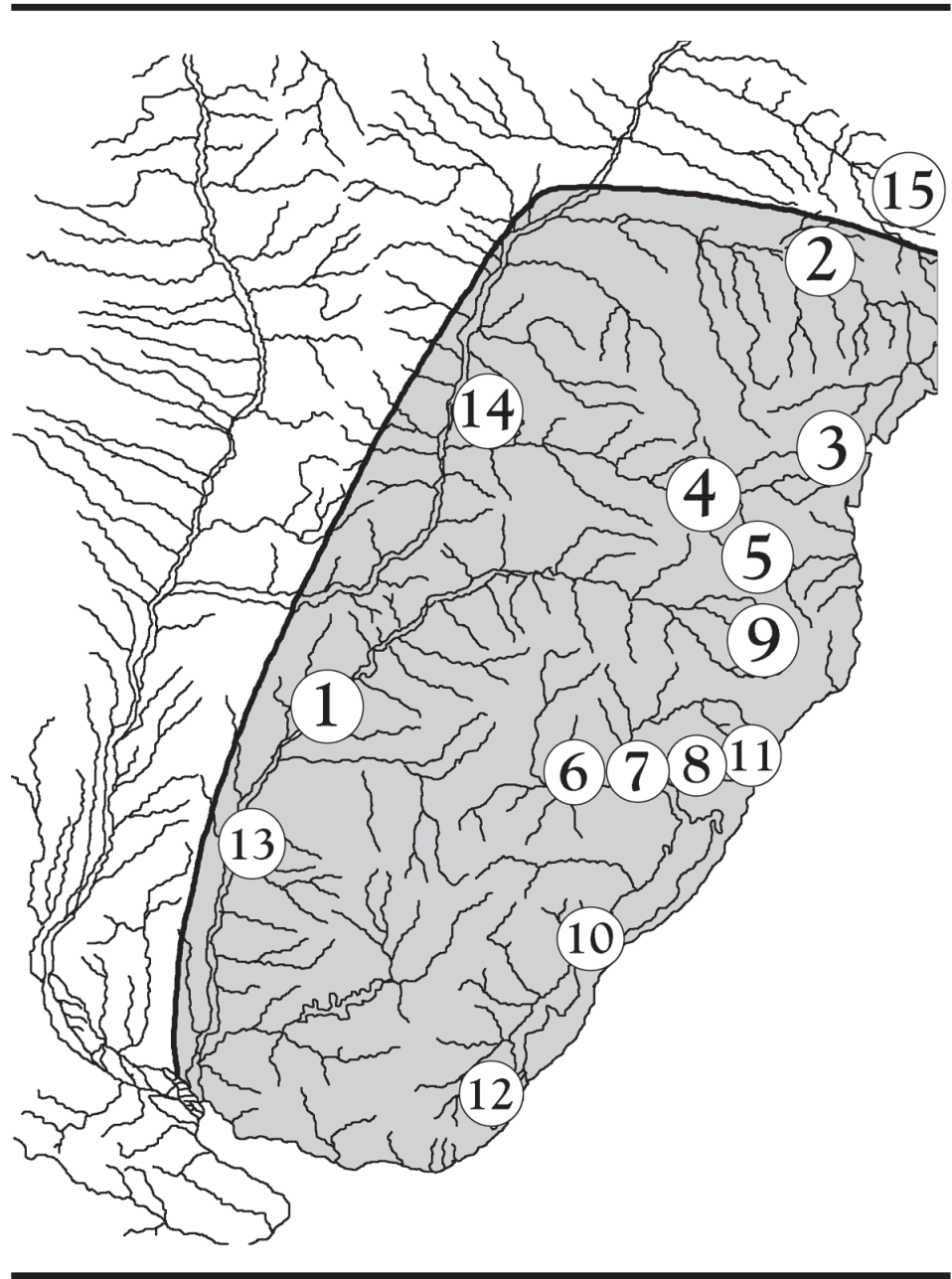

\section{TRADIÇÃO UMBU}

Os vestígios associados a esta tradição aparecem distribuídos por toda a Região Sul, Uruguai e sul de São Paulo, nos mais distintos ecossistemas e ambientes (Figura 3). O traço mais marcante que se verificou nas amostras estudadas é a longa persistência de padrões tecnológicos, com artefatos confeccionados com técnicas similares e, basicamente, com as mesmas matérias-primas, desde pelo menos 12.000 até 1.000 AP (Tabela 1). As pontas de projétil se destacam como objeto diagnóstico, embora os demais artefatos e resíduos de lascamento apresentem uma padronização tecnológica similar. A feição externa e a inserção ambiental de seus sítios arqueológicos são outros aspectos marcantes, que se repetem ao longo do tempo. Infelizmente, as informações estão limitadas aos artefatos e resíduos de lascamento e, em menor proporção, ao estudo de restos alimentares, não havendo pesquisas sobre o conteúdo dos sítios arqueológicos, suas populações e suas relações com ambiente. As persistências indicam padrões de reprodução de certos comportamentos tecnológicos e adaptativos, mas não há dados que garantam que tenha havido manutenção similar da organização social, política e econômica e outros aspectos culturais. 


\section{TABELA 1}

\section{Datações não-Calibradas da Tradição UmbU}

(A coluna " $n^{\circ}$ no mapa" indica onde estas informações estão situadas na Figura 3)

\begin{tabular}{|c|c|c|c|c|c|}
\hline Data AP & Sítio & Lab. № & Local & Fonte & $\begin{array}{c}\text { № } \\
\text { no mapa }\end{array}$ \\
\hline $4.650 \pm 170$ & Camargo & LRA & Piraju & Pallestrini e Chiara 1978 & 2 \\
\hline $2.060 \pm 230$ & Camargo & LRA & Piraju & Pallestrini e Chiara 1978 & 2 \\
\hline $1.030 \pm 85$ & Camargo & LRA & Piraju & Pallestrini e Chiara 1978 & 2 \\
\hline $1.250 \pm 50$ & BS22 & Gsy 9993 & Bairro da Serra & De Blasis 1996 & 15 \\
\hline $3.705 \pm 130$ & Céu Azul 1 & SI 1575 & S. José dos Pinhais & Schmitz 1978 & 3 \\
\hline $3.110 \pm 140$ & PR/UV/04 & SI 802 & União da Vitória & Chmyz 1977 & 4 \\
\hline $2.670 \pm 80$ & Céu Azul 1 & SI 1577 & S. José dos Pinhais & Smithsonian & 3 \\
\hline $1.035 \pm 90$ & PR/UV/03 & SI 803 & União da Vitória & Smithsonian & 4 \\
\hline $1.000 \pm 65$ & Céu Azul 1 & SI 1576 & S. José dos Pinhais & Smithsonian & 3 \\
\hline $755 \pm 60$ & Céu Azul 1 & SI 1578 & S. José dos Pinhais & Schmitz 1978 & 3 \\
\hline $730 \pm 50$ & PR/UV/O2 & SI 142 & União da Vitória & Schmitz 1978 & 4 \\
\hline $12.770 \pm 220$ & $\mathrm{RS} / \mathrm{I} / 50$ & SI 801 & Alegrete & Miller 1987 & 1 \\
\hline $12.690 \pm 100$ & $\mathrm{RS} / \mathrm{Q} / 02$ & SI 2351 & Quaraí & Miller 1987 & 1 \\
\hline $11.555 \pm 230$ & $\mathrm{RS} / \mathrm{IJ} / 68$ & SI 3750 & São Borja & Miller 1987 & 1 \\
\hline $10.985 \pm 100$ & $\mathrm{RS} / \mathrm{I} / 69$ & SI 2630 & Uruguaiana & Miller 1987 & 1 \\
\hline $10.810 \pm 275$ & $\mathrm{RS} / \mathrm{I} / 66$ & SI 2622 & Uruguaiana & Miller 1987 & 1 \\
\hline $10.800 \pm 150$ & $\mathrm{RS} / \mathrm{I} / 69$ & N 2523 & Uruguaiana & Miller 1987 & 1 \\
\hline $10.420 \pm 90$ & K 87 & $?$ & Salto & Hilbert 1991 & 1 \\
\hline $10.400 \pm 110$ & RS/I/69 & N 2521 & Uruguaiana & Miller 1987 & 1 \\
\hline $10.240 \pm 80$ & RS/I/69 & SI 3106 & Uruguaiana & Miller 1987 & 1 \\
\hline $10.200 \pm 125$ & $\mathrm{RS} / \mathrm{I} / 69$ & N 2522 & Uruguaiana & Miller 1987 & 1 \\
\hline $10.180 \pm 275$ & RS/I/98 & SI 3752 & Uruguaiana & Miller 1987 & 1 \\
\hline $9.855 \pm 130$ & $\mathrm{RS} / \mathrm{IJ} / 67$ & SI 3749 & Itaqui & Miller 1987 & 1 \\
\hline $9.840 \pm 105$ & $\mathrm{RS} / \mathrm{I} / 67$ & N 2519 & Itaqui & Miller 1987 & 1 \\
\hline $9.620 \pm 110$ & RS/I/69 & SI 2631 & Uruguaiana & Miller 1987 & 1 \\
\hline $9.605 \pm 120$ & RS/I/97 & SI 3754 & Uruguaiana & Miller 1987 & 1 \\
\hline $9.595 \pm 175$ & $\mathrm{RS} / \mathrm{IJ} / 67$ & SI 2637 & Itaqui & Miller 1987 & 1 \\
\hline $9.450 \pm 115$ & $\mathrm{RS} / \mathrm{I} / 72$ & SI 2634 & Uruguaiana & Miller 1987 & 1 \\
\hline
\end{tabular}




\begin{tabular}{|c|c|c|c|c|c|}
\hline $9.230 \pm 145$ & RS/I/67 & SI 2625 & Itaqui & Miller 1987 & 1 \\
\hline $9.120 \pm 340$ & $\mathrm{RS} / \mathrm{I} / 70$ & SI 2632 & Uruguaiana & Miller 1987 & 1 \\
\hline $9.035 \pm 100$ & RS/I/99 & SI 3755 & Itaqui & Miller 1987 & 1 \\
\hline $8.585 \pm 115$ & $\mathrm{RS} / \mathrm{IJ} / 67$ & SI 2636 & Itaqui & Miller 1987 & 1 \\
\hline $6.760 \pm 100$ & K 86 & $?$ & Salto & Hilbert 1991 & 13 \\
\hline $5.030 \pm 110$ & $?$ & $?$ & Salto & Hilbert 1991 & 13 \\
\hline $4.660 \pm 270$ & $?$ & ? & Salto & Hilbert 1991 & 13 \\
\hline $3.527 \pm 145$ & $\mathrm{RS} / \mathrm{IJ} / 62$ & SI 800 & Itaqui & Miller 1987 & 1 \\
\hline $910 \pm 200$ & Casa de Pedra & SI 227 & Urubicí & Piazza 1969 & 9 \\
\hline $610 \pm 65$ & $\mathrm{RS} / 314$ & SI 1195 & Uruguaiana & Brochado e Schmitz 1973 & 1 \\
\hline $670 \pm 88$ & H TA-CR 1 & NZA 4609 & Salto & Consens 1995 & 13 \\
\hline $660 \pm 80$ & $\mathrm{SC} / \mathrm{VI} / 10$ & SI 537 & Presidente Getúlio & Piazza 1974 & 5 \\
\hline $290 \pm 80$ & $\mathrm{SC} / \mathrm{VI} / 10$ & SI 536 & Presidente Getúlio & Piazza 1974 & 5 \\
\hline $9.430 \pm 360$ & RS/TQ/58 & BA 44739 & Montenegro & Ribeiro e Ribeiro 1999 & 7 \\
\hline $8.290 \pm 130$ & RS/TQ/58 & BA 32183 & Montenegro & Ribeiro et al. 1989 & 7 \\
\hline $8.020 \pm 150$ & RS/TQ/58 & BA 33458 & Montenegro & Ribeiro e Ribeiro 1999 & 7 \\
\hline $7.250 \pm 350$ & RS/TQ/58 & BA 44740 & Montenegro & Ribeiro e Ribeiro 1999 & 7 \\
\hline $5.655 \pm 140$ & $\mathrm{RS} / \mathrm{C} / 14$ & SI 1199 & S. Sebastião do Caí & Ribeiro 1974 & 7 \\
\hline $2.920 \pm 120$ & RS/RP/86 & SI 4795 & S. Cruz do Sul & Ribeiro 1991 & 6 \\
\hline $1.425 \pm 115$ & $\mathrm{RS} / \mathrm{RP} / 81$ & SI 4168 & Vera Cruz & Ribeiro 1983 & 6 \\
\hline $575 \pm 80$ & $\mathrm{RS} / \mathrm{S} / 308$ & SI 804 & S. Francisco de Paula & Brochado e Schmitz 1973 & 8 \\
\hline $5.950 \pm 190$ & $\mathrm{RS} / \mathrm{LN} / 1$ & SI 234 & Osório & Miller 1967 & 11 \\
\hline $5.689 \pm 240$ & $\mathrm{RS} / \mathrm{LN} / 1$ & SI 235 & Osório & Miller 1967 & 11 \\
\hline $4.280 \pm 180$ & $\mathrm{RS} / \mathrm{LN} / 1$ & SI 233 & Osório & Miller 1967 & 11 \\
\hline $2.435 \pm 85$ & $\mathrm{RS} / \mathrm{RG} / 21$ & SI 1006 & Rio Grande & Naue 1973 & 10 \\
\hline $2.160 \pm 80$ & $\mathrm{RS} / \mathrm{RG} / 1$ & SI 1194 & Rio Grande & Naue 1973 & 10 \\
\hline $2.000 \pm 120$ & $\mathrm{RS} / \mathrm{RG} / 1$ & SI 1193 & Rio Grande & Naue 1973 & 10 \\
\hline $4.035 \pm 150$ & $\mathrm{PR} / \mathrm{FI} / 43$ & SI 5044 & Foz do Iguaçu & Chmyz 1983 & 14 \\
\hline $4.360 \pm 70$ & Cabo Polonio & URU 005 & Rocha & Lopez s.d. & 12 \\
\hline $3.820 \pm 100$ & Potrerillo & URU 175 & Rocha & Lopez s.d. & 12 \\
\hline $3.790 \pm 90$ & Potrerillo & URU 083 & Rocha & Lopez s.d. & 12 \\
\hline
\end{tabular}




\section{Data AP}

\begin{tabular}{|c|c|c|c|c|c|}
\hline $3.050 \pm 50$ & San Miguel & URU s/n & Rocha & Lopez s.d. & 12 \\
\hline $3.000 \pm 50$ & Lag. Castillos & URU 55 & Rocha & Lopez s.d. & 12 \\
\hline $2.930 \pm 50$ & Pta. Coronilla & URU 105 & Rocha & Lopez s.d. & 12 \\
\hline $2.860 \pm 180$ & Los Índios & URU 128 & Rocha & Lopez s.d. & 12 \\
\hline $2.740 \pm 60$ & Pta. Coronilla & URU 040 & Rocha & Lopez s.d. & 12 \\
\hline $2.740 \pm 150$ & Potrerillo & URU 169 & Rocha & Lopez s.d. & 12 \\
\hline $2.700 \pm 150$ & Los Índios & URU 168 & Rocha & Lopez s.d. & 12 \\
\hline $2.580 \pm 400$ & Los Índios & URU 170 & Rocha & Lopez s.d. & 12 \\
\hline
\end{tabular}

Os estudos de antropologia física poderão contribuir para a explicação do fluxo gênico, mostrando se havia padrões preferenciais por troca local ou a longas distâncias, ou ambas. Também poderão contribuir para o reconhecimento dos relacionamentos sociais e políticos entre as populações Umbu, bem como trazer aportes para a compreensão de questões relacionadas ao meio ambiente e a padrões de circulação territorial.

A inexistência de escavações em superfície ampla, sociologicamente orientadas, torna infrutífero qualquer exercício demográfico em qualquer um dos períodos ao longo dos 11.000 anos de duração da Tradição Umbu. Da mesma forma, a inexistência de estudos com perspectivas regionais, que estabelecessem relação de contemporaneidade entre os sítios, impede que se possa inferir densidades demográficas e relações intersítios.

As populações da Tradição Umbu constituíam basicamente três tipos de habitação: 1) a céu aberto; 2) em abrigos-sobrocha (cavidade na rocha cuja abertura geralmente é maior que a profudidade); 3) nos dois últimos milênios, cerritos (estruturas monticulares, aterros artificais instalados em áreas alagadiças, com um formato geralmente circular com 30-40m de diâmetro médio, alcançando $3 \mathrm{~m}$ de altura em média, havendo exemplares com dimen- sões muito maiores, até 100 m de diâmetro), localizados na planície costeira, escudo sul-riograndense e campanha do Rio Grande do Sul e nas terras contíguas do Uruguai.

A tecnologia e a organização tecnológica das indústrias líticas constituem atualmente uma das principais preocupações relacionadas ao estudo da Tradição Umbu. Um exemplo desse tipo de reflexão é apresentado por Dias (1994). Estudando o conjunto lítico de um abrigo-sob-rocha no vale do Rio Caí, Rio Grande do Sul, ela demonstrou que este correspondia a um local onde a preparação de artefatos era a atividade predominante e que os seus ocupantes, por cerca de 6.000 anos, utilizaram proporcionalmente as mesmas matérias-primas e técnicas de lascamento, mantendo ao longo do tempo um padrão de artefatos e resíduos de lascamento. A autora verificou estatisticamente que a matéria-prima era buscada em fontes disponíveis nas proximidades do abrigo, onde abundam jazidas de arenito, basalto, calcedônia e quartzo. Também verificou que a tecnologia de produção empregada relaciona-se intimamente, de forma constante, com os tipos de materiais selecionados. Os artefatos de arenito e basalto foram predominantemente preparados através da percussão unipolar direta e por pressão, enquanto a calcedônia e o quartzo foram lascados com percussão bipolar em sua 
maioria, com baixa incidência de retoques e reativações do gume. Os resíduos de lascamento e os tipos de artefatos indicam que as atividades de redução primária e secundária eram preferencialmente realizadas no sítio, após terem seu córtex removido durante o processo de obtenção nas fontes de matéria-prima. Lascas unipolares grandes e médias foram reduzidas através de retoque por pressão e percussão, visando a produção de bifaces, pré-formas e pontas de projétil. Isso deixou grande quantia de resíduos de lascas secundárias pequenas e microlascas. Nas lascas unipolares usadas distingue-se uma categoria de tamanhos grandes, que apresentam retoque direto ou que foram usados sem qualquer forma de preparação. Igualmente, as formas das pontas de projétil apresentam relação com as tecnologias de produção empregadas, não apresentando alternância significativa no tempo que justificasse a definição de fases arqueológicas, podendo sua variação morfológica decorrer de aspectos funcionais, estilísticos ou estritamente tecnológicos, devido ao tipo de matéria-prima ou de padrões de reativação. O estudo das marcas de uso nas lascas unipolares revelou que as retocadas tinham função de raspar superfícies duras, enquanto as de gume sem retoque tinham maior evidência de função de cortar superfícies macias. Os artefatos bipolares foram preparados no sítio, visando produzir lascas que poderiam ser transformadas em pontas de projétil ou usadas para cortar e raspar. Os artefatos brutos foram levados ao sítio sem redução ou outra preparação prévia na fonte de matéria-prima, estando relacionados à produção de artefatos, como os percutores utilizados para produzir lascas e os polidores manuais. Os percutores estão associados às técnicas bipolar e unipolar, com função simultânea de percutor e bigorna. Os polidores manuais sugerem associação ao preparo de plataformas para o retoque por percussão ou pressão nas peças bifaciais. Também poderiam ter sido usados para moer, pilar, quebrar e macerar vegetais.

A partir desse estudo, a autora visou demonstrar a ampla gama de possibilida- des que a análise tecno-tipológica possibilita frente às limitações formais dos conceitos de tradição e fase do Pronapa, cujas balizas espaço-temporais tolhem a visão dos detalhes. É importante ressaltar que sua proposta pressupõe o entendimento de que pode haver variação entre os conjuntos líticos da Tradição Umbu em função da possibilidade de uso diferenciado de espaços e ambientes, ainda por ser explorado em futuras pesquisas.

A subsistência, ainda pouco estudada, revela alguns dados sobre a dieta da Tradição Umbu. Estudos realizados ou em andamento (Jacobus 1991, 1999) revelam que mamíferos, aves, répteis, peixes e moluscos faziam parte da alimentação dessas populações. Em termos vegetais, até o presente foram identificados cocos de palmeiras dos gêneros Arecastrum e Butia, comuns em todo o Sul. Jacobus também indica diversas espécies vegetais que poderiam ter sido consumidas na abundante flora da Região Sul.

A construção de túmulos associada a uma economia de exploração de "espectro rico", desde pelo menos 5.000 AP, no nordeste uruguaio, sugere uma realidade muito mais complexa do que a imaginada pelos pronapianos, uma vez que há possibilidade de sua função original ter servido para definir territorialidade e orientar os direitos de exploração e circulação regionais (cf. López 1999). Por volta de 2.700 AP, na mesma área, encontraram-se vestígios de uma provável "emergência de complexidade" e de desenvolvimento regional, com os túmulos ocupando espaços centrais nos assentamentos (López op. cit.)

A articulação da Tradição Umbu com populações de fora da Região Sul ainda é obscura, não havendo estudos detalhados que revelem tanto sua ligação biológica quanto cultural, apesar de indicadores que apontam para relações com populações da região pampeana. Alguns pesquisadores (Schmitz 1987, 1999; Ribeiro 1990, 1999) advogam que há uma estreita relação entre a Tradição Umbu e as indústrias líticas da Patagônia e do Pampa argentino. Seu limite norte seria o estado de São Paulo, embo- 
ra ainda não exista uma quantidade de informações suficientes para definir um limite com maior precisão.

A ocupação do espaço e as diversas datações, como se pode verificar no mapa (Figura 3 ) e na Tabela 1, permitem traçar um panorama aproximado da distribuição geográfica e da longa duração da Tradição Umbu. Todavia, não é possível definir direções no processo de ocupação do Sul, uma vez que o conjunto de pesquisas não é uniforme, havendo desigualdade na quantidade de datações (a maioria está no Rio Grande do Sul e na sua fronteira com Santa Catarina). Mas pode-se concluir que toda a Região Sul estava ocupada por volta de 4.700 AP. O Rio Grande do Sul já estava todo ocupado por volta de 7.000 AP, sendo que o médio Rio Uruguai apresenta datas que alcançam 11.000 AP (datas próximas de 13.000 AP vêm sendo contestadas por Milder 1994, 1995).

As datas mais recentes, por sua vez, sugerem que o processo de expansão territorial das populações Kaingang, Xokleng e Guarani foram gradativamente comprimindo e confinando as populações da Tradição Umbu a certo territórios, formando bolsões no planalto, onde há datas de até 600 anos atrás. É provável que essas populações, quando comprimidas, a exemplo da relação entre povos Maku e Tukano da Amazônia, tenham conseguido manter alguns territórios e autonomia, havendo possibilidade de ter trocado pessoas e realizado algum tipo de comércio. Todavia, ainda não há como saber se as populações Umbu do Planalto sobreviviam ao tempo do contato com os brancos, a partir de 400 anos atrás, ou se foram completamente assimilados pelos conquistadores Kaingang, Xokleng e Guarani. Na região da Campanha, no Rio Grande do Sul e Uruguai, encontramos populações historicamente conhecidas como Charrua, Minuano, Guenoas, Bohanes e Yaros que parecem ser descendentes da tradição Umbu, uma vez que existe similaridade notável entre seus registros arqueológicos.

Por volta de 2.500 anos atrás, especialmente nas áreas contíguas à Planície Cos- teira e porção sudoeste do Rio Grande do Sul, e no litoral uruguaio, as populações associadas à Tradição Umbu passam a construir aterros, conhecidos entre os arqueólogos como cerritos. Os cerritos são indicadores de uma nova forma de assentamento em áreas alagadiças, cuja motivação ainda é discutida. Não há certeza se esta mudança decorre de uma nova forma de organização espacial e adaptabilidade aos ambientes de banhado, altamente rentáveis em termos de recursos de subsistência, ou se é devida à pressão populacional que obrigava essas populações a estabelecerem estratégias específicas de controle dos recursos nas áreas de ecossistemas úmidos.

Posteriormente, há cerca de 2.100 AP as populações dos cerritos passam a utilizar cerâmica com formas simples, definida no Sul do Brasil como Tradição Vieira. É muito provável que as populações que elaboravam a Tradição Umbu no Rio Grande do Sul e Uruguai tenham estabelecido relações de contato e troca com as populações Jê e Guarani quando estas estavam colonizando a bacia do Jacuí, passando a elaborar a cerâmica Vieira. Isto é deduzido das características próprias das cerâmicas Guarani e Jê que foram encontradas nas cerâmicas Vieira de diversos cerritos da Planície Costeira e do Escudo Sul-Riograndense no Rio Grande do Sul.

\section{TRADIÇÃO VIEIRA}

Os sítios desta tradição estão inseridos nos ambientes alagadiços próximos ao litoral Atlântico, na região da Campanha, assim como no entorno e sobre o Escudo Sul-Riograndense, entre o Rio Grande do Sul e o Uruguai (Figura 4). Seus assentamentos principais estão situados basicamente nos últimos níveis dos cerritos e, próximo da costa, sobre dunas (Schmitz 1976; Rütschiling 1989; González 1998; Lopez s.d.).

Ainda que faltem dados biológicos para estabelecer uma relação definitiva de continuidade, os dados históricos associados aos arqueológicos influenciaram diversos 
pesquisadores a definir os Minuano, os Charrua como as populações que produziam a cultura material diretamente relacionada à Tradição Vieira. Porém, ainda não foi realizada nenhuma pesquisa exaustiva nas fontes disponíveis em busca de dados que permitissem obter a ligação definitiva dessa relação de continuidade e de outros aspectos, como etnicidade, variações no registro arqueológico e outras diferenças ou semelhanças entre essas populações. Portanto, a questão da continuidade deveria ser testada em futuro próximo, com o objetivo de resolver definitivamente se as populações da Tradição Vieira “descendem" das populações da Tradição Umbu.

O que caracteriza a Tradição Vieira é a cerâmica com vasilhas de bases planas ou convexas, tamanhos pequenos, com formas de contorno simples, infletidos, ou uma com-

\section{FIGURA 4}

\section{Área da Tradição VieIra e RePresentação dos}

\section{PONTOS DATADOS}

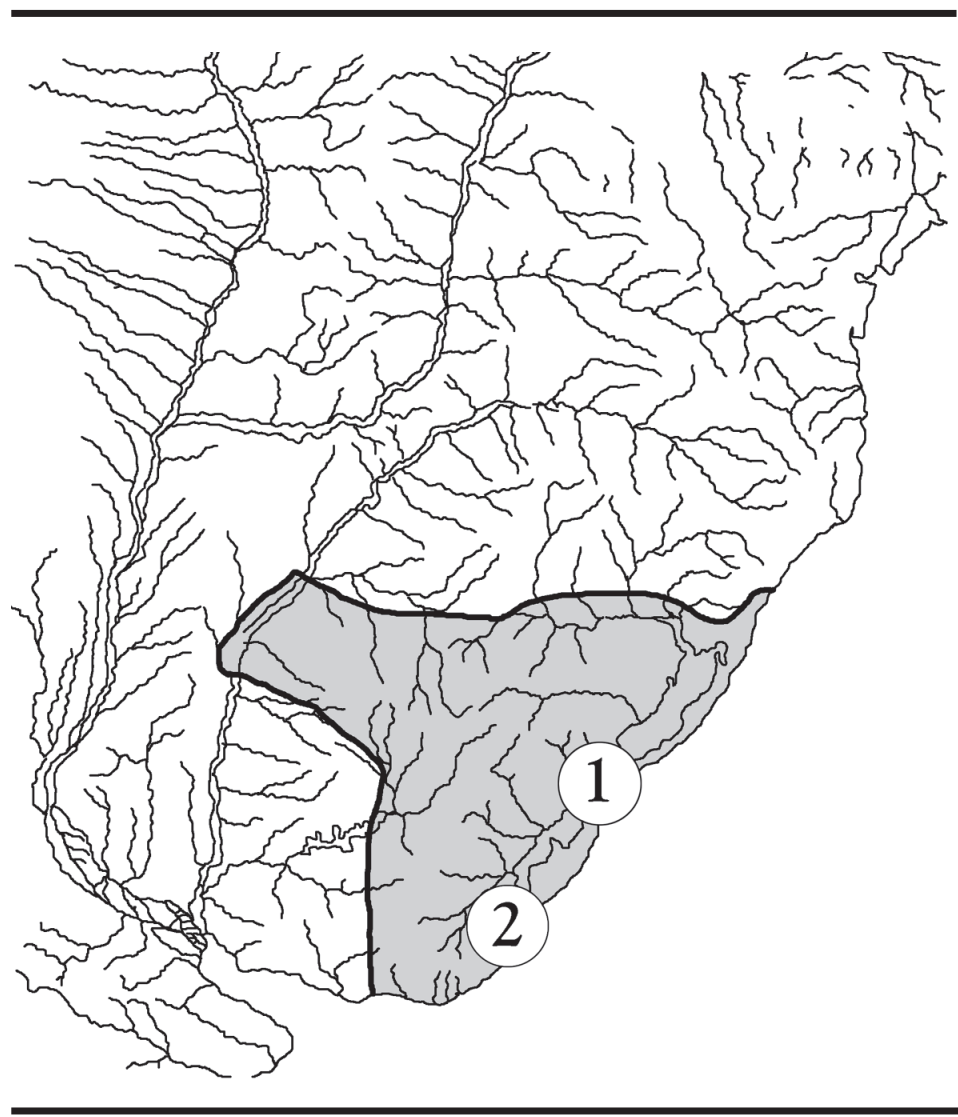

binação de ambas, com os maiores diâmetros alcançando até $42 \mathrm{~cm}$. No Rio Grande do Sul as vasilhas possuem algumas características próprias das cerâmicas feitas tanto pelos Jê do Sul quanto pelos Guarani, sugerindo indícios de trocas e contatos das populações da Tradição Umbu com os povos que vieram de fora da Região Sul.

Os artefatos líticos, as matérias-primas e o sistema de produção possuem características comuns aos sítios Umbu e Vieira que aparecem sobrepostos nos cerritos e, eventualmente, nas dunas. Nos cerritos próximos da costa uruguaia foram notados dois sistemas de assentamento, dependendo do ambiente de inserção: mais próximos do mar e dos sistemas lagunares litorâneos aparecem artefatos indicadores de ocupações contínuas; os distantes do litoral, nas porções mais elevadas, possuem indicadores de ocupação de curta duração, possivelmente acampamentos de caça e coleta.

A subsistência nos sítios do litoral é de alta rentabilidade, baseada na pesca, na caça e na coleta de vegetais, enquanto a do interior ainda não foi estudada. As pesquisas na região costeira do Uruguai e Rio Grande do Sul apontam para uma mobilidade sazonal entre a costa, nas estações mais quentes, e o interior nas mais frias. No litoral parece haver uma concentração demográfica mais acentuada, enquanto nos sítios do interior é menor, indicando que no inverno seus ocupantes se dispersavam para a obtenção de recursos de caça. A cerâmica não está associada com agricultura de derrubada e queima, uma vez que vestígios de vegetais de cultivo ainda não foram encontrados, excetuando o de palmeiras do gênero Butia.

A construção dos cerritos e, posteriormente, a cerâmica não representam uma distinção entre a tradição Umbu e a Tradição Vieira. Isso parece estar representando uma nova forma de adaptação ecológica diante de uma pressão causada pelas populações que vinham colonizando áreas da Região Sul e adjacências a partir de 3.000 AP (Tabela 2). Essas colonizações vinham reduzindo e restringindo as áreas de circulação das populações Umbu. Enquanto nas áreas do Planalto não parece haver mudan- 
ças materiais e adaptativas, como foi comentado na parte sobre a Tradição Umbu, as populações da área com registros Vieira parecem ter passado por um processo de adaptação às áreas alagadiças, pois passaram a habitar o seu interior, bem como a novas formas de processar os alimentos utilizando a cerâmica.

Os cerritos mais antigos até o presente remontam a 2.500 AP, enquanto a cerâmica Vieira mais antiga é de 2.000 AP. Eles parecem representar estratégias alternativas para superar o processo de confinamento que aumentava gradativamente, conforme a penetração das populações Jê do Sul, Guarani e dos grupos Aruak (que se instalaram na área de Entre Ríos). Entre 2.000 e 1.400 AP, à medida que o litoral, os sistemas lagunares da Planície Costeira e os principais rios e afluentes do Escudo Cristalino e da Campanha no Rio Grande do Sul e oeste do Uruguai vão sendo colonizados pelos Guarani, as populações V ieira foram empurradas para o interior. A partir dos séculos XVII e XVIII, com o colapso dos Guarani devido ao impacto da presença européia, há um esvaziamento e uma redução da pressão demográfica, liberando as áreas próximas do litoral e das margens do Rio Uruguai. Isso permitiu que as populações Minuano e Charrua reocupassem áreas de seus "ascendentes" Umbu e Vieira.

\section{TABELA 2}

\section{DataçõES NÃO-CAlibradas da Tradição Vieira}

(A coluna " $n^{\circ}$ no mapa" indica onde estas informações estão situadas na Figura 4)

\begin{tabular}{|c|c|c|c|c|c|}
\hline Data AP & Sítio & Lab. № & Local & Fonte & $\begin{array}{c}\text { № } \\
\text { no mapa }\end{array}$ \\
\hline $2.020 \pm 50$ & RS/RG/49 & SI 1008 & Rio Grande & Naue 1973 & 1 \\
\hline $1.355 \pm 45$ & RS/RG/48 & SI 1007 & Rio Grande & Naue 1973. & 1 \\
\hline $845 \pm 75$ & $\mathrm{RS} / \mathrm{RG} / 4$ & SI 1005 & Rio Grande & Naue 1973 & 1 \\
\hline $200 \pm 80$ & RS/RG/1 & SI 1191 & Rio Grande & Naue 1973 & 1 \\
\hline $2.530 \pm 60$ & $\mathrm{CH} 2 \mathrm{DO} 1 \mathrm{~B}$ & URU 22 & Rocha & Lopez s.d. & 2 \\
\hline $2.450 \pm 100$ & CH1E01 & BA 32198 & Rocha & Lopez s.d. & 2 \\
\hline $2.430 \pm 60$ & $\mathrm{CH} 2 \mathrm{DO} 1 \mathrm{~B}$ & URU 21 & Rocha & Lopez s.d. & 2 \\
\hline $2.350 \pm 60$ & CH2DO1B & URU 23 & Rocha & Lopez s.d. & 2 \\
\hline $2.320 \pm 50$ & Potrerillo & URU 082 & Rocha & Lopez s.d. & 2 \\
\hline $2.110 \pm 80$ & CH1E01 & BA 32190 & Rocha & Lopez s.d. & 2 \\
\hline $2.090 \pm 90$ & $\mathrm{CH} 2 \mathrm{DO} 1 \mathrm{~A}$ & KR 109 & Rocha & Lopez s.d. & 2 \\
\hline $1.835 \pm 120$ & CH2DO1A & URU 20 & Rocha & Lopez s.d. & 2 \\
\hline $1.700 \pm 90$ & $\mathrm{CH} 2 \mathrm{DO} 1$ & URU 53 & Rocha & Lopez s.d. & 2 \\
\hline $1.700 \pm 100$ & CH2DO1B & URU 13 & Rocha & Lopez s.d. & 2 \\
\hline $1.610 \pm 50$ & $\mathrm{CH} 2 \mathrm{DO} 1$ & URU 30 & Rocha & Lopez s.d. & 2 \\
\hline $1.350 \pm 160$ & CH2DO1A & AC 1198 & Rocha & Lopez s.d. & 2 \\
\hline
\end{tabular}




\begin{tabular}{|c|c|c|c|c|c|}
\hline Data AP & Sítio & Lab. № & Local & Fonte & $\begin{array}{c}\text { № } \\
\text { no mapa }\end{array}$ \\
\hline $1.090 \pm ?$ & $\mathrm{CH} 2 \mathrm{DO} 1 \mathrm{~B}$ & URU 24 & Rocha & Lopez s.d. & 2 \\
\hline $770 \pm 85$ & Los Índios & URU 135 & Rocha & Lopez s.d. & 2 \\
\hline $610 \pm 65$ & Cabo Polonio & URU 004 & Rocha & Lopez s.d. & 2 \\
\hline $400 \pm 50$ & $\mathrm{CH} 2 \mathrm{DO} 1 \mathrm{~A}$ & BA 32192 & Rocha & Lopez s.d. & 2 \\
\hline $340 \pm 115$ & $\mathrm{CH} 2 \mathrm{DO} 1 \mathrm{~A}$ & AC 1190 & Rocha & Lopez s.d. & 2 \\
\hline $290 \pm 75$ & $\mathrm{CH} 2 \mathrm{DO} 1 \mathrm{~A}$ & URU 19 & Rocha & Lopez s.d. & 2 \\
\hline $220 \pm 55$ & $\mathrm{CH} 2 \mathrm{DO} 1 \mathrm{~A}$ & URU 14 & Rocha & Lopez s.d. & 2 \\
\hline $190 \pm 40$ & CH2DO1A & AC 1195 & Rocha & Lopez s.d. & 2 \\
\hline
\end{tabular}

\section{FIGURA 5}

\section{Área da Tradição Humaitá e representação}

\section{DOS PONTOS DATADOS}

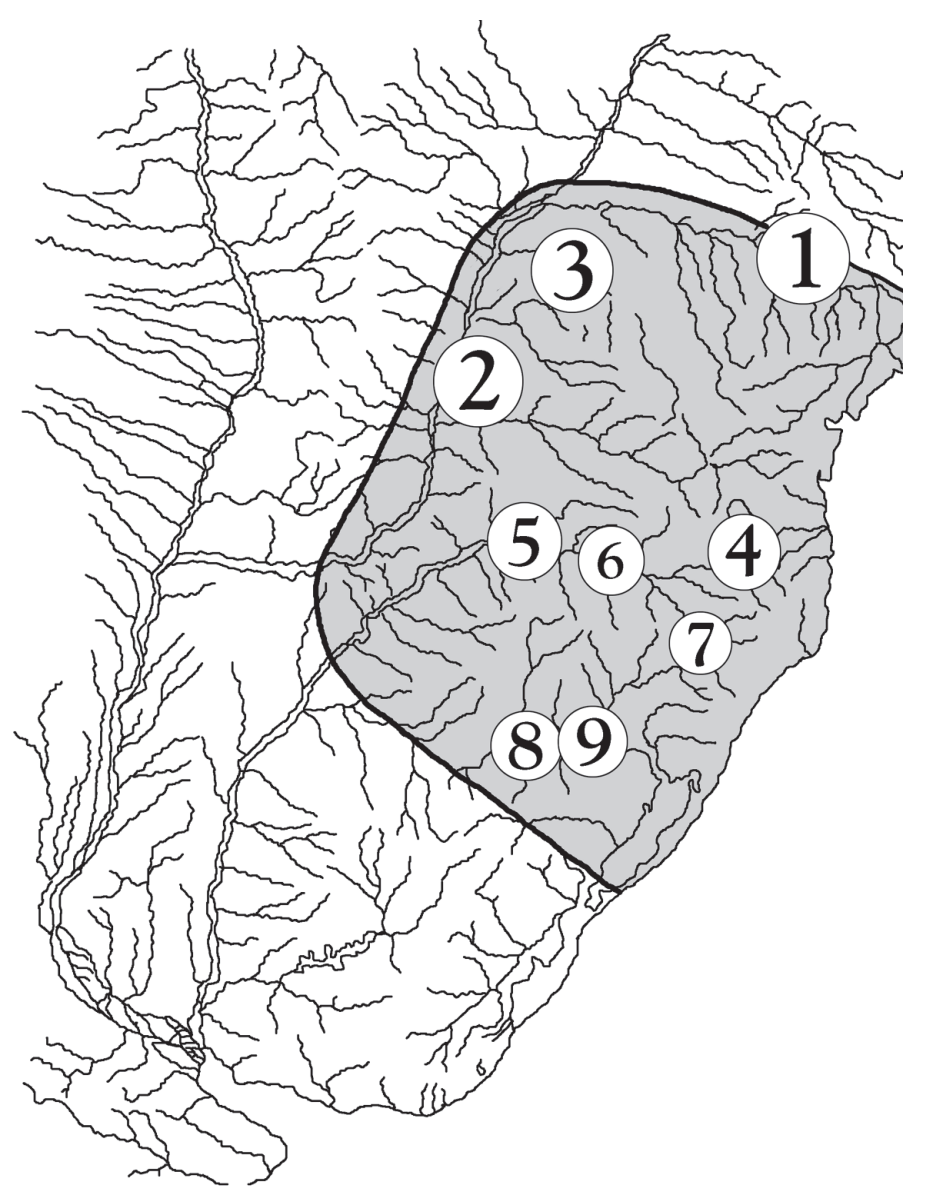

\section{TRADIÇÃO HUMAITÁ}

Esta tradição difere em poucos aspectos da Tradição Umbu, a tal ponto que alguns pesquisadores sugeriram que as diferenças representam variações em termos de funcionalidade dos sítios, ao invés de representarem populações distintas. Ambas as tradições ocupam basicamente o mesmo espaço geográfico, excetuando a área ao sul do Rio Jacuí no caso Humaitá, e apresentam datações similares, a partir da faixa dos 8.000 AP (Tabela 3). Os tipos de sítios ocupados também são os mesmos, excetuando os cerritos localizados na área ao sul do Jacuí (Figura 5). A partir dos pressupostos de Meggers e Evans (1977) foi usada basicamente a oposição ponta de projétil (Umbu) x grandes artefatos bifaciais (Humaitá) para amparar as distinções, sem a preocupação de analisar os contextos arqueológicos, artefatos e resíduos de lascamento, bem como os esqueletos de suas populações.

Tradicionalmente também foi alegado que as diferenças eram relativas aos ambientes onde os sítios estavam inseridos: predomínio de ambientes campestres para a Tradição Umbu e predomínio de florestas no caso da Tradição Humaitá. O caso dos ambientes é um problema crucial: como afirmar que as fisionomias ambientais do presente se mantiveram ao longo de 11.000 
ou 12.000 anos, uma vez que é sabido que houve importantes variações climáticas em nível global, que afetaram as características vegetais do Sul do Brasil?

Isso só começou a ser testado e revisto há pouco tempo, quando Hoeltz ([1995] 1997) realizou um detalhado estudo estatístico comparado sobre a tecnologia das tradições Umbu e Humaitá do vale do Rio Pardo, Rio Grande do Sul. Esse estudo de caso serve como exemplo para levantar problemas de pesquisa em outras áreas da Região Sul do Brasil, onde ainda não houve a preocupação em analisar estatisticamente os dados. A autora constatou que as matérias-primas e as etapas de produção dos artefatos observam padrões similares nas duas tradições e concluiu que são muito semelhantes, apresentando características comuns com as detectadas por Dias no vale do Rio Caí (Hoeltz 1997: 135). Porém, a autora pôde observar diferenças significativas que ocorrem ao nível técnico da produção dos artefatos, trazendo novos aportes para distinguir as duas tradições.

Ela verificou que na Tradição Umbu os artefatos bifaciais são confeccionados basicamente sobre seixos e lascas unipolares, com tamanhos de pequenos a médios e cobertos por superfície natural em até $1 / 3$ ou mais de sua área. Na Tradição Humaitá os artefatos bifaciais foram confeccionados a partir de blocos com tamanhos variando de médios até extra-grandes, cobertos por superfície natural em até $2 / 3$ ou mais de sua área. Já os resíduos de lascamento não apresentaram aspectos que evidenciassem distinções entre as tecnologias Umbu e Humaitá, revelando serem muito semelhantes.

\section{TABELA 3}

\section{Datações não-calibradas da Tradição Humaitá}

(A coluna "no no mapa" indica onde estas informações estão situadas na Figura 5)

\begin{tabular}{|c|c|c|c|c|c|}
\hline Data AP & Sítio & Lab. № & Local & Fonte & $\begin{array}{c}\text { № } \\
\text { no mapa }\end{array}$ \\
\hline $7.020 \pm 70$ & Brito & Gsy 6250 & Sarutaiá & Vialou 1983-84 & 1 \\
\hline $5.080 \pm 60$ & Brito & Gsy 6253 & Sarutaiá & Vialou 1983-84 & 1 \\
\hline $4.260 \pm 60$ & Brito & Gsy 6251 & Sarutaiá & Vialou 1983-84 & 1 \\
\hline $3.920 \pm 60$ & Brito & Gsy 6254 & Sarutaiá & Vialou 1983-84 & 1 \\
\hline $3.600 \pm 160$ & Almeida & Gsy & Tejupá & Pallestrini 1975 & 1 \\
\hline$* \pm 2.400$ & Almeida & IEA & Tejupá & Vialou 1980 & 1 \\
\hline$* \pm 1.500$ & Almeida & IEA & Tejupá & Pallestrini 1975 & 1 \\
\hline $310 \pm 50$ & $\mathrm{PR} / \mathrm{JA} / 5$ & SI 139 & Cambará & Smithsonian & 1 \\
\hline $6.910 \pm 75$ & $\mathrm{PR} / \mathrm{FI} / 21$ & SI 4994 & Foz do Iguaçu & Chmyz 1983 & 2 \\
\hline $6.505 \pm 105$ & $\mathrm{PR} / \mathrm{FI} / 21$ & SI 5993 & Foz do Iguaçu & Chmyz 1983 & 2 \\
\hline $6.265 \pm 80$ & $\mathrm{PR} / \mathrm{FI} / 21$ & SI 4992 & Foz do Iguaçu & Chmyz 1983 & 2 \\
\hline $4.065 \pm 75$ & $\mathrm{PR} / \mathrm{FO} / 49$ & SI 5045 & Guaíra & Chmyz 1983 & 2 \\
\hline $2.850 \pm 60$ & $\mathrm{PR} / \mathrm{FI} / 21$ & SI 4995 & Foz do Iguaçu & Chmyz 1983 & 2 \\
\hline $2.035 \pm 70$ & $\mathrm{PR} / \mathrm{FI} / 21$ & SI 4991 & Foz do Iguaçu & Chmyz 1983 & 2 \\
\hline
\end{tabular}




\begin{tabular}{|c|c|c|c|c|c|}
\hline Data AP & Sítio & Lab. № & Local & Fonte & $\begin{array}{c}\text { № } \\
\text { no mapa }\end{array}$ \\
\hline $6.685 \pm 175$ & José Vieira & Gsy 78 & Cidade Gaúcha & L.Emperaire 1968 & 3 \\
\hline $5.380 \pm 110$ & $\mathrm{PR} / \mathrm{QN} / 1$ & SI 1014 & Mirador & Chmyz 1977 & 3 \\
\hline $5.240 \pm 150$ & José Vieira & Gsy 80 & Cidade Gaúcha & L.Emperaire 1968 & 3 \\
\hline $3.435 \pm 175$ & José Vieira & Gsy 82 & Cidade Gaúcha & L.Emperaire 1968 & 3 \\
\hline $3.000 \pm 120$ & $\mathrm{SC} / \mathrm{U} / 13$ & SI 441 & Alfredo Wagner & Brochado et al. 1969 & 4 \\
\hline $8.640 \pm 95$ & $\mathrm{SC} / \mathrm{U} / 6$ & SI 995 & Itapiranga & Schmitz e Brochado 1972 & 5 \\
\hline $8.095 \pm 90$ & $\mathrm{SC} / \mathrm{U} / 6$ & SI 994 & Itapiranga & Smithsonian & 5 \\
\hline $7.260 \pm 100$ & $\mathrm{SC} / \mathrm{U} / 53$ & SI 440 & Itapiranga & Simões 1972 & 5 \\
\hline $7.145 \pm 120$ & $\mathrm{SC} / \mathrm{U} / 6$ & SI 993 & Itapiranga & Schmitz 1978 & 5 \\
\hline $5.930 \pm 140$ & $\mathrm{SC} / \mathrm{VP} / 38$ & SI 827 & Itá & Schmitz 1978 & 6 \\
\hline $675 \pm 50$ & $\mathrm{RS} / \mathrm{VZ} / 52$ & SI 799 & Três Passos & Kern 1981 & 6 \\
\hline $6.620 \pm 175$ & $\mathrm{RS} / \mathrm{A} / 8$ & SI 933 & Bom Jesus & Schmitz e Brochado 1972 & 7 \\
\hline $2.945 \pm 85$ & $\mathrm{RS} / \mathrm{MJ} / 14$ & SI 1001 & Nova Palma & Schmitz e Brochado 1972 & 8 \\
\hline $2.795 \pm 55$ & $\mathrm{RS} / \mathrm{SM} / 7$ & SI 1004 & S. Pedro do Sul & Schmitz e Brochado 1972 & 8 \\
\hline $2.190 \pm 80$ & Ivorá & Beta 129549 & Ivorá & Brochado (com. pessoal 1999) & 8 \\
\hline $1.920 \pm 50$ & $\mathrm{RS} / ?$ & SI 811 & Bom Jesus & Schmitz 1978 & 7 \\
\hline $1.165 \pm 35$ & $\mathrm{RS} / \mathrm{MJ} / 14$ & SI 1000 & Nova Palma & Brochado e Schmitz 1973 & 8 \\
\hline $380 \pm 80$ & $\mathrm{RS} / \mathrm{RP} / 81$ & SI 4166 & Vera Cruz & Ribeiro 1983 & 9 \\
\hline
\end{tabular}

(* = termoluminescência)

\section{POVOS JÊDO SUL}

São conhecidos historicamente como Kaingang e Xokleng, de matriz cultural Macro-Jê, falantes de línguas distintas da família Jê e originários do Centro-Oeste do Brasil (Maybury-Lewis 1979; Urban 1992). Constituem dois povos distintos lingüística, biológica e culturalmente, como vimos acima, porém os arqueólogos ainda não diferenciaram seus registros arqueológicos no Sul do Brasil, similares tanto ao nível dos contextos quanto dos artefatos e resíduos diversos (Figura 6).

Nos termos do Pronapa foram definidos como "Tradição Itararé”, "Tradição
Casa de Pedra" e "Tradição Taquara", desconsiderando-se os dados históricos e etnográficos. Além disso, na interpretação que constitui um dos maiores enganos da arqueologia do Sul do Brasil, considerouse que essas três tradições eram a continuidade regional da Tradição Humaitá, tendose imaginado que esta teria adotado por difusão a cerâmica, a agricultura e as técnicas de polimento lítico. Demonstrei em outro trabalho (Noelli 1999a) que a prática de ignorar a história do desenvolvimento das idéias americanistas pela arqueologia brasileira fez com que os pesquisadores seguissem acriticamente a interpretação de Oswaldo Menghín (1957), que postulou, sem dados, esta improvável continuidade 
regional. Ao contrário dessa interpretação, dados lingüísticos, biológicos e antropológicos atestam que os Kaingang e Xokleng são populações de matriz cultural Jê vindos de outras áreas, e que ocuparam a maior parte dos três estados da região $\mathrm{Su}$ (Noelli 1999a).

As relações internas na família lingüística Jê colocam a língua Kaingang no conjunto Akwén (Xakriabá, Xavante e Xerente) e Apinayé, nos estados de Minas Gerais, Mato Grosso e Goiás (Davis 1966 Rodrigues 1986). Observando o mapa de distribuição dos povos falantes dessas línguas (Nimuendajú 1981), verifica-se que ocupavam continuamente as terras mais altas do Planalto Brasileiro desde o Centro-Oeste do Brasil, iniciando com os Xerente na bacia do Rio Tocantins e os Xavante no Araguaia. No baixo curso do Araguaia os Apinayé; os Xakriabá na área do divisor de águas das bacias dos altos cursos do Tocantins, São Francisco e Paraná. Os Xokleng estão no grupo das línguas Kayapó, Timbira, Kren-akarôre e Suyá (Davis 1966, 1968; Rodrigues 1986). No mesmo mapa vemos a localização dos Kayapó nas bacias do Xingu e Paraná, dos Timbira na área oriental do baixo Rio Tocantins, dos Suyá no alto curso do Xingu e dos Kren-akarôre no médio curso do Rio São Manoel.

A organização social dos Kaingang e Xokleng guarda semelhanças com os padrões dos grupos Jê mencionados acima, com sistemas duais, metades exogâmicas e seções hierarquicamente dispostas, uxorilocalidade, bem como em outros elementos sociais e políticos (Urban 1978; Veiga 1994; Tommasino 1995). Os Kaingang, mais conhecidos até o momento, contêm outros elementos culturais comuns aos outros povos Jê centrais, a exemplo das relações entre as metades clânicas, trocas rituais e a pintura corporal.

Os registros arqueológicos dos Jê do Sul apresentam variabilidade devida aos processos de invasão e conquista dos seus territórios que, por exemplo, forçaram mudanças que são arqueologicamente sensíveis no padrão de assentamento e de enter- ramento. Primeiro os Guarani, que entre 2.000 e 1.000 AP foram empurrando-os para longe das proximidades dos grandes rios e principais afluentes, confinando-os nas terras mais altas e frias da Região Sul. Num segundo momento, por volta de 700 AP, foram expulsos do litoral, também sendo empurrados pelos Guarani para cima do Planato Sul-Brasileiro, em áreas próximas do litoral. Depois vieram os europeus, que a partir do século XVI conseguiram vencer os Guarani com epidemias, guerras, escravidão e assimilação, intensificando depois do século XVIII o processo de conquista das terras dos Jê do Sul. No século XX as frentes brasileiras de colonização travaram uma contínua guerra de conquista que os confinou em ínfimas áreas chamadas de "terras indígenas", tuteladas pela Funai. Os Xokleng quase foram extintos como sociedade no

FIGURA 6

\section{Área dos povos Jê do Sul E REPRESENTAÇÃo DOS PONTOS DATADOS}

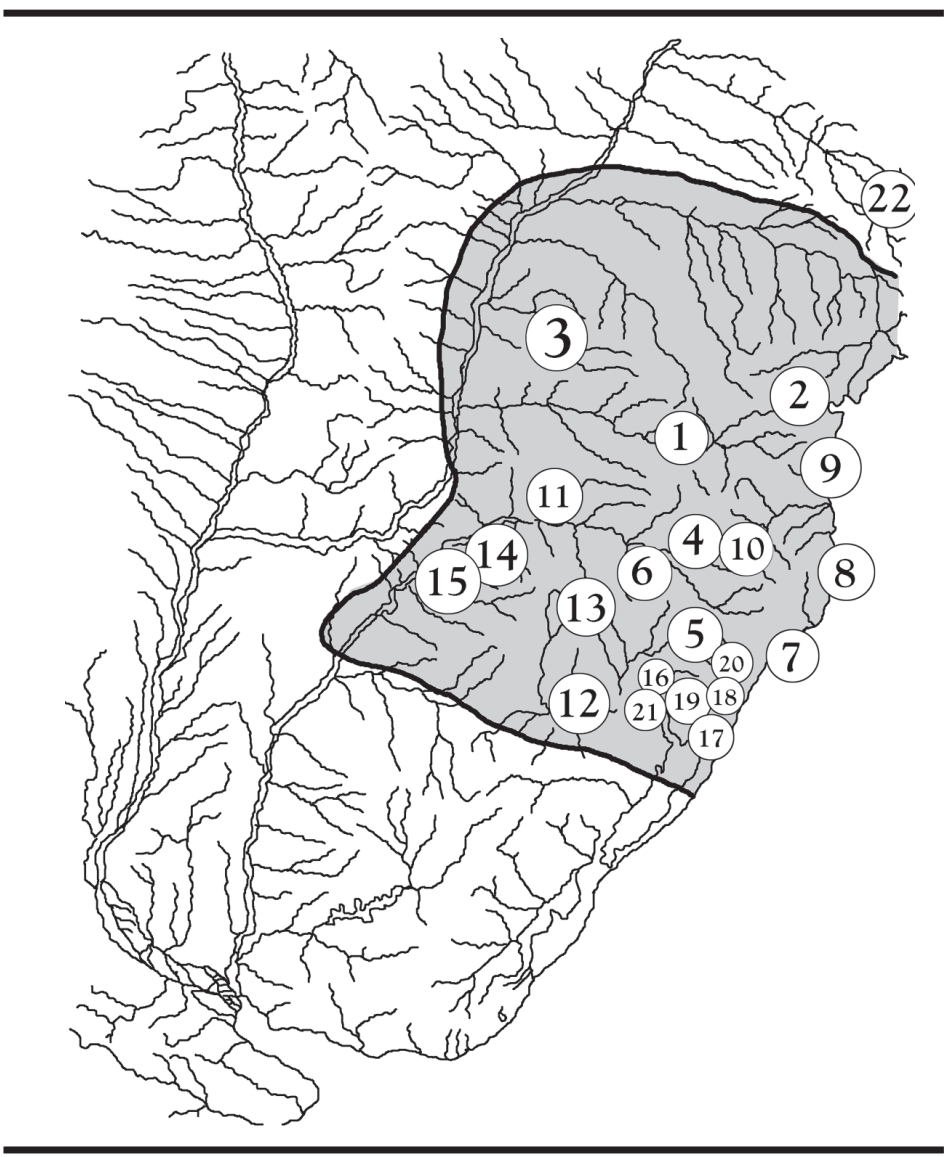


início do século XX, mas resistiram e atualmente são cerca de 1.000 pessoas.

O século XVII, com o impacto da presença européia, foi palco de uma drástica mudança na configuração demográfica e no tamanho dos territórios. A devastação dos Guarani causada por epidemias, guerras, escravidão e fugas para outras áreas, deixou espaços praticamente desabitados, facilitando uma redistribuição dos Jê do Sul, que se expandiram e passaram a dominar os vales do Tibagi, Piquiri e Ivaí no estado do Paraná, bem como o noroeste do Rio Grande do Sul. O alto-médio Iguaçu, os baixos vales que deságuam no Atlântico e o litoral catarinense foram reocupados pelos Xokleng, que logo passaram a sofrer pressões dos brasileiros que vinham conquistando o litoral no início do século XVIII.

O processo contínuo de guerra e desterritorialização causou mudanças significativas na cultura material, nos padrões de adaptação e na organização social e política. A depopulação afetou o padrão social e político de se organizar, em função de desarranjos sociais e desequilíbrio demográfico entre as metades clânicas, especialmente entre os Xokleng que estiveram próximos do etnocídio no início do século XX. Ao mesmo tempo a desterritorialização influenciou mudanças nos padrões de subsistência, com a perda das áreas de agricultura e de diversas espécies de plantas manejadas, criando uma falsa imagem de que os Xokleng sempre teriam sido caçadorescoletores. A perda e a mudança dos territórios influenciaram no abandono temporário ou definitivo de certos tipos de assentamentos, artefatos e práticas que necessitavam dos padrões tradicionais em equilíbrio, dependentes da territorialidade fixa, como as habitações semi-subterrâneas, a cerâmica e os enterramentos sem cremação (em diversos casos realizados em montículos).

Fontes do século XVII ao início do XX descrevem os Jê do Sul em sua vida cotidiana e contêm dados úteis à interpretação arqueológica (porexemplo Prezia 1997; Reis 1997). Como a metodologia pronapiana ignorou-as, perdeu-se a oportunidade de avançar a construção da história e cultura dos
Kaingang e Xokleng, sendo este um trabalho que somente agora se inicia. Por exemplo, foi descrito de modo genérico ou específico o uso e a confecção de vasilhas cerâmicas desde o século XVIII, além do registro de outros elementos da cultura material e dos seus empregos cotidianos, além de diversas informações sociologicamente úteis. A revisão dessas fontes evitaria a inútil "reinvenção da roda" feita pelos pronapianos, pois os arqueólogos teriam vislumbrado imediatamente a óbvia existência das populações Kaingang e Xokleng.

Através das fontes que descreveram as cerâmicas, Silva (s.d.) localizou as seguintes informações, comparado-as: 1) processos de seleção, 2) extração e tratamento da matéria-prima; 3 ) técnicas de construção; 4) secagem; 5) queima; 6) acabamento de superfície. Assim, identificou aspectos gerais do sistema tecnológico e das cadeias operatórias da produção da cerâmica, verificando elementos que demonstram a continuidade entre os Kaingang, Xokleng e seus ascendentes pré-coloniais, concluindo que "são bastante semelhantes, principalmente no que se refere ao processo de manufatura e, mais especificamente, à construção do vasilhame" (Silva s.d.).

Isso contribui para demonstrar que essas cerâmicas possuem uma tecnologia e uma aparência comuns, definidas a partir da mesma matriz cultural dos povos Jê. Considerando que as razões culturais, além das estritamente materiais, podem ter influenciado na uniformidade de escolha de certos elementos (matéria-prima, antiplástico, acabamentos de superfície, etc.), Silva (op. cit.) sugere o abandono da perspectiva pronapiana sobre as três tradições, deixando claro que a cerâmica não é o indicador adequado para estabelecer as diferenças entre os Kaingang e Xokleng, sendo necessário buscar outros indicadores.

Os arqueólogos do Sul do Brasil tradicionalmente só compararam "cacos”, restringindo-se a descrever e quantificar os atributos antiplástico, cor e tratamento de superfície. Não buscaram definir semelhanças e diferenças nas classes de vasilhas, bem como reconhecer padrões formais e 
de uso sociologicamente definidos, tanto em nível local como regional. Da mesma maneira, ainda não há um padrão de reconstrução gráfica das vasilhas que defina os modelos a serem seguidos, havendo ainda dúvidas quanto às formas reconstruídas. As coleções mais completas revelam que a maioria das vasilhas possui tamanhos pequenos (até 1 litro) e médios (até 5-6 litros), revelando que a cerâmica Jê do Sul era dividida entre pratos e diferentes tipos de panelas, caçarolas, tostadores e para outras funções (Miller 1978). Os maiores (até 60 litros) ocorrem em menor proporção, tendo sido utilizados como panelas de cozinha e como talhas para preparar e servir o kifé, uma bebida fermentada alcoólica à base de mel e milho usada em beberagens coletivas "profanas". Também teriam a mesma função para outra bebida fermentada alcoólica chamada kiki, consumida na festa anual em homenagem aos mortos.

De modo geral os assentamentos são semelhantes entre os Kaingang e os Xokleng, que ocuparam tanto aldeias a céu aberto, quanto abrigos-sob-rocha, sambaquis e casas semi-subterrâneas. Destaco as casas semi-subterrâneas como um dos indicadores de sedentarismo e permanência em territórios definidos, havendo casos de assentamentos com até 60 ou 70 casas cujas dimensões maiores podem alcançar mais de 20 metros de diâmetro e 11 metros de profundidade. Especialmente no caso Xokleng, houve uma mudança no padrão de assentamento, forçada primeiro pela pressão Guarani e Kaingang, depois pelos brancos. A contínua pressão sobre seus territórios obrigou-os a viver em pequenos grupos em constante movimento, deixando poucos rastros, instalando-se em acampamentos provisórios, feitos com tecnologia expediente e de manufatura e uso, ditados conforme as necessidades momentâneas, resultando em pouco esforço e tempo de trabalho, sendo descartados logo após o seu uso.

As práticas funerárias constituem um problema em aberto, não resolvido pela abordagem do Pronapa e pelas precárias pesquisas feitas pelos historiadores. É co- mum atribuir a cremação dos mortos aos Xokleng e, aos Kaingang, o enterramento coberto por um montículo de terra com dimensões que podiam alcançar até 3 ou 4 metros de altura e diâmetros de até 50 metros. Os Kaingang mantiveram sua tradição até poucas décadas atrás, construindo montículos sobre seus enterramentos. As evidências arqueológicas indicam que a cremação Xokleng passou a ocorrer devido à desterritorialização e à constante mobilidade causada pela conquista tanto ao tempo dos Guarani quanto dos brancos. As fontes históricas, cuja maioria foi confeccionada na "fronteira" da invasão branca sobre os territórios Xokleng, apresentam a cremação como prática, mas desconsideraram o constante processo de fuga que obrigou os Xokleng a tornarem-se "nômades". Se forem observados os assentamentos do litoral catarinense e paranaense atribuídos à Tradição Itararé, principalmente os datados entre 300 e 1.000 AP (Tabela 4), nota-se que os corpos eram enterrados sem cremação, em cemitérios. Depois de 1.000 AP, considerando o processo de invasão e conquista do litoral atlântico pelos Guarani e, depois, pelos brancos, as informações sobre enterramentos sem cremação diminuem e desaparecem.

Os Jê do Sul eram e ainda são povos agricultores, como nos informam as fontes arqueológicas e escritas. A interpretação precária dessas fontes e a imagem de nomadismo criada nas fronteiras do Sul do Brasil, somadas ao preconceito e à aversão que os intelectuais tinham em relação aos Kaingang e Xokleng, resultaram na falsa crença sobre populações caçadoras-coletoras que adotaram a agricultura após o contato com os brancos. Felizmente diversos estudos vêm mostrando que, de fato, esta imagem é fruto de uma ideologia que justificava a expropriação das terras indígenas para as oligarquias paulistas e paranaenses (Monteiro 1992a; Prezia 1997; Mota 1998), assim como para a instalação de frentes de colonização européia que vinham “branquear" o Sul do Brasil (Gonçalves 1996). A falta de pesquisas interdisciplinares levou os pesquisadores a segui- 
TABELA 4

Datações não-Calibradas dos sítios arqueológicos Jê do Sul no Sul do Brasil (A coluna " $n^{\mathrm{o}}$ no mapa" indica onde estas informações estão situadas na Figura 6)

\begin{tabular}{|c|c|c|c|c|c|}
\hline Data AP & Sítio & Lab. № & Local & Fonte & $\begin{array}{c}\text { № } \\
\text { no mapa }\end{array}$ \\
\hline $595 \pm 50$ & BS19 & Gsy 10040 & Bairro da Serra & De Blasis 1996 & 22 \\
\hline $270 \pm 60$ & Torre de Pedra & Gsy 10041 & Bairro da Serra & De Blasis 1996 & 22 \\
\hline $1.475 \pm 65$ & $\mathrm{PR} / \mathrm{UV} / 17$ & SI 2197 & União da Vitória & Chmyz 1981 & 1 \\
\hline $848 \pm 70$ & $\mathrm{PR} / \mathrm{CT} / 53$ & Beta 22644 & Campo Largo & Chmyz 1995 & 2 \\
\hline $810 \pm 90$ & $\mathrm{PR} / \mathrm{UV} / 12$ & SI 892 & Bituruna & Smithsonian & 1 \\
\hline $800 \pm 50$ & PR/UV/1 & SI 141 & União da Vitória & Chmyz 1968 & 1 \\
\hline $680 \pm 70$ & $\mathrm{PR} / \mathrm{UV} / 11$ & SI 1010 & Bituruna & Smithsonian & 1 \\
\hline $623 \pm 120$ & $\mathrm{PR} / \mathrm{UV} / 12$ & SI 691 & Bituruna & Schmitz 1988 & 1 \\
\hline $558 \pm 50$ & $\mathrm{PR} / \mathrm{CT} / 53$ & Beta 22646 & Campo Largo & Chmyz 1995 & 2 \\
\hline $255 \pm 100$ & $\mathrm{PR} / \mathrm{UV} / 12$ & SI 692 & Bituruna & Schmitz 1988 & 1 \\
\hline $855 \pm 95$ & $\mathrm{PR} / \mathrm{UB} / 4$ & SI 2193 & Ubiratã & Chmyz 1978 & 3 \\
\hline $735 \pm 95$ & PR/UB/4 & SI 2194 & Ubiratã & Chmyz 1981 & 3 \\
\hline $470 \pm 95$ & $\mathrm{PR} / \mathrm{UB} / 4$ & SI 2192 & Ubiratã & Chmyz 1978 & 3 \\
\hline $1.920 \pm 50$ & SC/CL/? & SI 811 & São Joaquim & Smithsonian & 4 \\
\hline $1.810 \pm 85$ & $\mathrm{RS} / \mathrm{P} / 12$ & SI 813 & Bom Jesus & Schmitz e Brochado 1972 & 5 \\
\hline $1.117 \pm 80$ & $\mathrm{SC} / \mathrm{CL} / ?$ & SI 810 & São Joaquim & Schmitz e Brochado 1972 & 4 \\
\hline $950 \pm 80$ & $\mathrm{RS} / \mathrm{P} / 27$ & SI 812 & Bom Jesus & Schmitz e Brochado 1972 & 5 \\
\hline $650 \pm 55$ & $\mathrm{RS} / \mathrm{PE} / 28 \mathrm{a}$ & SI 6563 & Esmeralda & Ribeiro e Ribeiro 1985 & 6 \\
\hline $635 \pm 45$ & $\mathrm{RS} / \mathrm{PE} / 26 \mathrm{a}$ & SI 6561 & Esmeralda & Ribeiro e Ribeiro 1985 & 6 \\
\hline $465 \pm 40$ & $\mathrm{RS} / \mathrm{PE} / 10 \mathrm{a}$ & SI 6558 & Esmeralda & Ribeiro e Ribeiro 1985 & 6 \\
\hline $420 \pm 55$ & $\mathrm{RS} / \mathrm{PE} / 28 \mathrm{a}$ & SI 6562 & Esmeralda & Ribeiro e Ribeiro 1985 & 6 \\
\hline $390 \pm 50$ & $\mathrm{RS} / \mathrm{PE} / 10 \mathrm{a}$ & SI 6556 & Esmeralda & Ribeiro e Ribeiro 1985 & 6 \\
\hline $355 \pm 50$ & $\mathrm{RS} / \mathrm{PE} / 1 \mathrm{Ob}$ & SI 6559 & Esmeralda & Ribeiro e Ribeiro 1985 & 6 \\
\hline $1.580 \pm 60$ & SC/IÇ/01 & Beta 72196 & Içara & Schmitz 1995 & 7 \\
\hline $1.470 \pm 60$ & $\mathrm{SC} / \mathrm{IÇ/01}$ & Beta 72197 & Içara & Schmitz 1995 & 7 \\
\hline $1.140 \pm 180$ & Tapera & SI 245 & Florianópolis & Chmyz 1976 & 8 \\
\hline $1.030 \pm 180$ & Tapera & SI 246 & Florianópolis & Schmitz 1988 & 8 \\
\hline $880 \pm 100$ & Marechal Luz & M 1202 & Ilha São Francisco & Bryan 1965 & 9 \\
\hline
\end{tabular}




\begin{tabular}{|c|c|c|c|c|c|}
\hline Data AP & Sítio & Lab. No & Local & Fonte & $\begin{array}{c}\text { No } \\
\text { no mapa }\end{array}$ \\
\hline $800 \pm 70$ & Tapera & SI 243 & Florianópolis & Smithsonian & 8 \\
\hline $1.300 \pm 70$ & $\mathrm{RS} / \mathrm{PF} / \mathrm{O} 1$ & SI 601 & Passo Fundo & Schmitz 1988 & 13 \\
\hline $975 \pm 95$ & $\mathrm{SC} / \mathrm{U} / 35$ & SI 825 & Concórdia & Schmitz e Brochado 1972 & 11 \\
\hline $830 \pm 60$ & $\mathrm{RS} / \mathrm{VZ} / 43$ & SI 598 & Tenente Portela & Miller 1969 & 14 \\
\hline $400 \pm 100$ & $\mathrm{RS} / \mathrm{VZ} / 25$ & SI 600 & Porto Lucena & Miller 1969 & 15 \\
\hline $330 \pm 90$ & $\mathrm{SC} / \mathrm{CL} / 10$ & SI 597 & Urubici & Schmitz 1988 & 10 \\
\hline $160 \pm 70$ & $\mathrm{RS} / \mathrm{VZ} / 44$ & SI 599 & Tenente Portela & Miller 1969 & 14 \\
\hline $1.740 \pm 65$ & $\mathrm{RS} / \mathrm{S} / 359$ & SI 2344 & Santo Antônio & Smithsonian & 17 \\
\hline $1.655 \pm 65$ & $\mathrm{RS} / \mathrm{S} / 328$ & SI 2345 & Santo Antônio & Smithsonian & 17 \\
\hline $1.520 \pm 90$ & $\mathrm{RS} / 40$ & SI 607 & Caxias do Sul & Schmitz 1969 & 16 \\
\hline $1.515 \pm 105$ & $\mathrm{RS} / \mathrm{A} / 2$ & SI 805 & S. Francisco de Paula & Smithsonian & 18 \\
\hline $1.480 \pm 70$ & $\mathrm{RS} / 127$ & SI 603 & Caxias do Sul & Schmitz 1969 & 16 \\
\hline $1.385 \pm 95$ & $\mathrm{RS} / \mathrm{A} / 2$ & SI 806 & S. Francisco de Paula & Smithsonian & 18 \\
\hline $1.380 \pm 110$ & $\mathrm{RS} / \mathrm{S} / 282$ & SI 414 & Sapiranga & Brochado et al. 1969 & 19 \\
\hline $1.330 \pm 100$ & $\mathrm{RS} / 127$ & SI 605 & Caxias do Sul & Schmitz 1969 & 16 \\
\hline $1.190 \pm 100$ & $\mathrm{RS} / ?$ & SI 409 & Taquara & Brochado et al. 1969 & 19 \\
\hline $1.140 \pm 40$ & $\mathrm{RS} / 127$ & SI 602 & Caxias do Sul & Schmitz 1967 & 16 \\
\hline $970 \pm 95$ & $\mathrm{RS} / \mathrm{A} / 2$ & SI 808 & S. Francisco de Paula & Schimtz 1988 & 18 \\
\hline $915 \pm 145$ & $\mathrm{RS} / \mathrm{RP} / 164 \mathrm{~b}$ & SI 4066 & Santa Cruz do Sul & Ribeiro 1980 & 12 \\
\hline $840 \pm 60$ & $\mathrm{RS} / 127$ & SI 606 & Caxias do Sul & Schmitz 1969 & 16 \\
\hline $700 \pm 60$ & RS/A/8 & SI 2343 & Ausentes & Schmitz 1988 & 20 \\
\hline $630 \pm 70$ & $\mathrm{RS} / 127$ & SI 604 & Caxias do Sul & Schmitz 1967 & 16 \\
\hline $630 \pm 205$ & $\mathrm{RS} / \mathrm{C} / 12$ & SI 1201 & São Sebastião do Caí & Ribeiro 1974 & 21 \\
\hline $620 \pm 90$ & $\mathrm{RS} / 68$ & SI 608 & Caxias do Sul & Schmitz 1967 & 16 \\
\hline
\end{tabular}

rem a interpretação superficial de Alfred Métraux (1946; Ploetz e Métraux 1930), definindo os Jê do Sul indevidamente como "horticultores incipientes" e "atrasados na pesca”. As informações arqueológicas e históricas sobre os Kaingang são bastante completas. As referentes aos Xokleng são incompletas, restritas às arqueológicas, mas revelam uma mudança considerável que os forçou a abandonar a agricultura antes da invasão européia.

Em nível geral, as fontes históricas e etnográficas mostram uma adaptação muito bem integrada aos variados ecótonos do Suldo Brasil, tanto no manejo agroflorestal quanto nas atividades de caça e pesca. É possível afirmar que desenvolviam um sistema de manejo similar ao verificado entre 
os Kayapó, estudados por Posey e colegas, bem como ao reconhecido em outros povos da Amazônia. Por exemplo, todas as fontes mostram a relação dos Jê do Sul com a coleta de pinhão de araucária (Araucaria angustifolia), considerado item básico da dieta vegetal. Também apontam a importância dos palmitos de Euterpe, da fécula do caule de pindo (Arecastrum romanzofianum), os cocos de butiá (Butia capitata, Butia eriosphata), assim como várias espécies frutíferas. A botânica revela que no Sul do Brasil havia alta freqüência de comunidades vegetais onde predominava uma espécie, alcançando áreas de considerável extensão, como os pinheirais de araucária, os butiazais, os palmitais, os jaboticabais, os ervais e outras plantas menos consideradas/conhecidas pelos não-indígenas. Diversas comunidades vegetais situadas nos territórios dos Jê do Sul constituíam florestas antropogênicas, manejadas por eles ao longo de 2.000 anos. A drástica redução da densidade populacional deixou áreas manejadas abandonadas, com recursos vegetais disponíveis para serem coletados por outras populações que, pressionadas pelo avanço das fronteiras de invasores brancos ou Guarani, fugiam de suas terras. Isso causou a falsa impressão de nomadismo e da dependência da coleta quando, de fato, os grupos derrotados nas guerras de resistência fugiam para áreas que já conheciam graças às redes de intercâmbio e aos laços de parentesco ou aliança. A extensão das áreas manejadas e a sazonalidade de várias espécies permitiam uma subsistência centrada na coleta, associada às práticas de obtenção de proteína animal baseada na caça e na coleta.

A agricultura foi documentada entre os Kaingang, que desenvolviam tecnologias típicas de cultivo em clareiras na floresta e em outros lugares, exemplo dos povos amazônicos. Ainda não há, como veremos abaixo para o caso Guarani, uma completa definição sobre todas as plantas cultivadas e qual a variedade de cultivares que haveria por espécie (Tabela 5). A prática de plantar em locais separados das roças, em clareiras naturais, à beira da mata e nos caminhos, bem como cultivar espécies que produzem por mais de 15,20 anos, mesmo nas áreas em pousio, como o cará e algumas variedades de feijão, levou muitos cronistas que desconheciam botânica e técnicas de manejo ambiental a pensarem que isso era uma simples coleta de plantas selvagens.

As proteínas de origem animal eram obtidas através da caça generalizada, da pesca e da coleta de insetos. Os Jê do Sul consumiam mamíferos, aves, peixes, répteis, anfíbios, moluscos e insetos, obtidos com armas de uso individual ou por meio de engenhosas armadilhas, tanto de modo

TABELA 5

Alguns cultivares de agricultura dos Kaigang

\begin{tabular}{|c|c|c|c|}
\hline \multirow{5}{*}{ Tuberosas } & Nome popular & Nome científico & № de cultivares \\
\hline & Mandioca & Manihot esculenta & $?$ \\
\hline & Batata doce & Ipomoea batatas & $?$ \\
\hline & Batata "inglesa" & Solanum tuberosum & $?$ \\
\hline & Cará & Dioscorea sp & $?$ \\
\hline \multirow{3}{*}{ Graníferas } & Milho & Zea mais & 5 \\
\hline & Feijões & Phaseolus sp & $?$ \\
\hline & Amendoim & Arachis hypogaea & $?$ \\
\hline
\end{tabular}


individual como coletivamente. As fontes históricas indicam que o acesso seletivo era o preferencial. Usavam também armadilhas de caça, espalhadas pelas áreas de cultivo, que atraíam uma fauna variada de roedores e aves. A maioria dos sítios arqueológicos está próxima de cursos d'água piscosos e, para pescar, conforme as fontes históricas, era intensamente utilizado o pãri, uma armadilha de corredeira com uma barreira que conduz os peixes para um cesto que os captura em quantidades controladas (Mota et al. 1996). Nas águas de remansos e outros locais sem correnteza empregavam ictiotóxicos. Os grupos que viviam à beira-mar ou em cursos d'água que nele desaguavam utilizavam intensamente seus recursos, como a pesca generalizada, as piracemas e a coleta intensa de moluscos, como mostram os dados arqueológicos.

O consumo de insetos era outra prática que provia quantidades consideráveis de proteínas e energia. Várias espécies de larvas eram cultivadas intencionalmente, através da derrubada para apodrecimento de certas espécies arbóreas ou coletadas durante seus ciclos naturais, como as larvas de palmáceas (Rynchophorus palmarum) e de borboletas que eram depositadas em certas espécies de taquaras (Morpheis smerinta). Cupins (por exemplo: Cornitermes cumulans e Procornitermes striatus), formigas (por exemplo: Atta sexdens piriventris), abelhas e vespas (várias espécies) podiam ser consumidos tanto sob forma larval como na fase adulta. Vários tipos de mel e partes de colméias eram consumidos e as ceras eram usadas na produção da cultura material e em outras finalidades, como a vedação.

Um aspecto importante, que também induziu à interpretação de nomadismo, era a estratégia de circular pelo território de domínio, em diversas áreas satélites da aldeia principal onde predominavam certos tipos de oferta de alimentos. O início do ciclo anual parece ter sido regido pelo cultivo na roça. Encerrada a plantação, havia uma dispersão de grupos afins que se dirigiam para áreas com concentrações de diversas plantas de coleta, provavelmente em áreas mais antigas de manejo, onde iam consumir pinhões, palmitos e outros alimentos. Esses pontos muitas vezes estavam associados com áreas de caça de certas espécies ou com cursos d'água onde eram instaladas suas armadilhas de pesca nas épocas de piracema (Mota, Noelli e Silva 1996; Noelli, Mota e Silva 1996).

Havia diversas técnicas de estocagem de alimentos, tanto animais quanto vegetais, que podiam preservar os alimentos por vários meses, até um ano, garantindo reservas extras de alimento. As carnes eram desidratadas no moquém ou sob o sol, e os vegetais, principalmente o pinhão, eram hidratados e depositados em silos subterrâneos e cestos em locais úmidos.

\section{POVOS GUARANI}

Dentre as populações do Sul os Guarani são os mais conhecidos em termos arqueológicos, etnográficos, históricos e linguiísticos (ainda não foram alvo de estudos de antropologia física)(5). Os Guarani formam um conjunto de populações de matriz cultural Tupi, mais especificamente vinculados aos povos Tupi-guarani (Viveiros de Castro 1986). A gênese cultural dos Guarani está situada em algum lugar da bacia dos rios Madeira-Guaporé, no sudoeste da Amazônia(Rodrigues 1964; Noelli 1996a). Em processo de contínuo crescimento demográfico e de ocupação territorial se expandiram para o Sul, conquistando paulatinamente uma vasta área composta por partes do Brasil, Paraguai, Argentina, Uruguai e Bolívia (Brochado 1984).

A partir de uma revisão exaustiva da bibliografia Guarani, de estudos arqueológicos e visitas a diversas coleções de museus e sítios arqueológicos do Sul do Brasil, Paraguai, Uruguai e Argentina (Figura 7), feitos nos últimos 12 anos, foi possível concluir que os Guarani tinham a prescritividade como norma. As pessoas nãoGuarani e as "coisas novas" eram incorporadas e enquadradas nos seus códigos e estruturas. As inúmeras fontes indicam que os Guarani eram "radicalmente" prescritivos,
5 Este texto é baseado em publicações minhas e dos colegas losé Brochado, Gislene Monticelli e André Soares (cf. referências). 
reproduzindo-se continuamente com pouca variabilidade na cultura material. Caso contrário, a contínua assimilação de pessoas de outras etnias e a adaptação aos ambientes do Sul do Brasil poderiam resultar em mudanças significativas e evidentes. É preciso reconhecer que os Guarani representam diversas populações que tinham em comum língua, cultura material, tecnologia, subsistência, padrões adaptativos, organização sociopolítica, religião, mitos, etc. Há, evidentemente, variações em nível dialetal, de adaptabilidade e de etnicidade. Em que pese a necessidade de mais estudos, verifica-se entre os Guarani diferenças que não aparecem em nível material.

$\mathrm{O}$ que garantia essa reprodução era a

\section{FIGURA 7}

\section{Área GuARANI E REPRESENTAÇão DOS PONTOS}

\section{DATADOS}

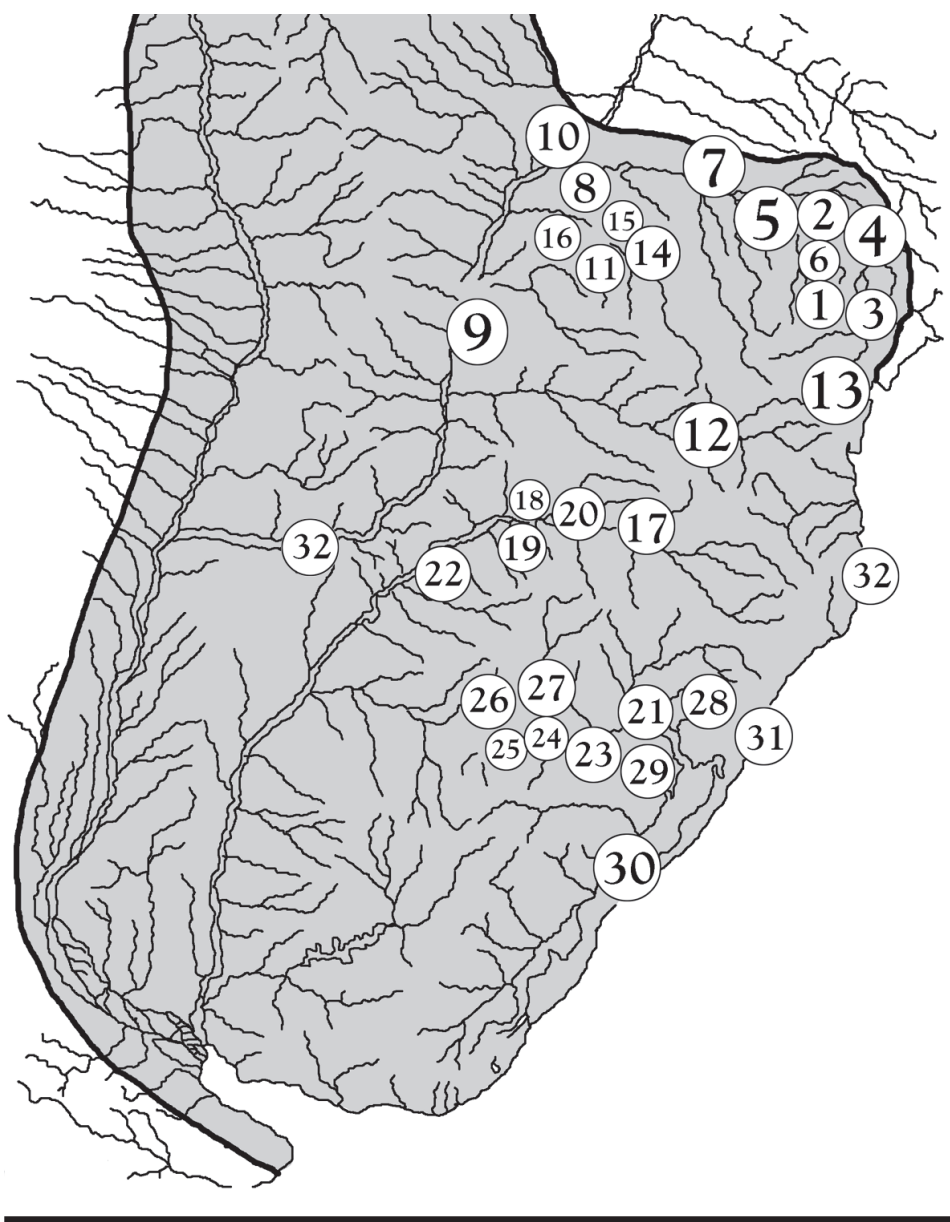

plasticidade da organização social, política e do parentesco de um lado e, do outro lado, a grande capacidade de se adaptar ao meio, adquirindo novidades para a subsistência, medicina e matérias-primas. Essa reprodução só seria possível através de uma intensa e contínua troca de informações, objetos e pessoas aldeia-a-aldeia, tanto em nível local quanto regional, até alcançar distâncias longínquas no interior do imenso território de falantes do Guarani, descritos pelos europeus nos séculos XVI e XVII. As novas informações e objetos deviam ser rapidamente incorporados na rede de significados, o que pode explicar a notória uniformidade da estrutura que amarra os diversos itens que compõem a cultura Guarani.

A organização sociopolítica e o sistema de parentesco, de acordo com as informações dos séculos XVI e XVII (Soares 1997), tinham por base a estrutura complexa e a localidade do tipo kindred. Ou seja, famílias extensas compostas por várias famílias nucleares reunidas em torno de uma liderança política e/ou religiosa a partir de laços de parentesco que poderiam ser tanto sangüíneo, quanto político e/ou adotivo. Nem a matrilocalidade nem a patrilocalidade funcionavam como fator agregador, mas sim o prestígio de um líder com capacidade de organizar grupos guerreiros ou de trabalho, com qualidades de bom orador, guerreiro, agricultor, caçador, articulista político e provedor de grandes festas. As famílias extensas compunham-se de um número variável de famílias nucleares, que poderia atingir 60 ou mais, residindo em uma única casa. As maiores aldeias podiam conter até 4 ou 5 famílias extensas, havendo relatos de assentamentos com 3.000 habitantes, mas a média parece estar restrita a populações em torno de 600-300 pessoas. Considerando estimativas "conservadoras", a partir de uma revisão parcial em fontes históricas do século XVII, a família nuclear seria composta em média por 6 membros. Havia possibilidade de existir até 7 gerações convivendo em uma família extensa, o que pode aumentar a média do tamanho local da família nuclear. A poligamia é outro fator que também con- 
tribuía para ampliar essa média, especialmente nos assentamentos bem posicionados na hierarquia regional.

Um aspecto importante a ser considerado para explicar o sucesso conquistador dos Guarani é a tendência a incorporar o "outro", o “não-Guarani". Por meio de alianças ou assimilação à custa das contínuas guerras de conquista, tendiam a "guaranizar" pessoas de outras etnias, incorporando-as. Essa prática de ampliar o fluxo gênico parece ser um comportamento padrão entre os povos Tupi, pois grupos atuais revelaram altos índices de distância genética, devido à existência de uma acentuada troca gênica intertribal (Salzano e Callegari-Jacques 1991).

Em termos gerais de adaptação, os Guarani eram relativamente autônomos em relação às ofertas do ambiente, pois tinham a capacidade de transportar e inserir um “pacote básico" com suas plantas úteis na maioria das regiões que conquistaram ao sul da Amazônia. Ao mesmo tempo trocavam experiências com outros povos ou estudavam os recursos florísticos dos novos ecótonos conquistados, incorporando no seu pacote outros itens alimentícios, medicinais e materiais. O sistema de manejo ambiental e a prática da agricultura nos mesmos moldes em outros povos Tupi da Amazônia (Balée 1994) permitiam manter uma estável capacidade de suporte e níveis adequados de alimentação. A fauna de fora da Amazônia também foi intensamente assimilada para obtenção de proteínas, energia, medicina e matéria-prima.

As fontes históricas e etnográficas mostram que os Guarani eram generalistas em termos dietários, não demonstrando restrições definitivas na alimentação. Os tabus alimentares são relacionados a momentos específicos do ciclo de vida ou a opções exclusivamente pessoais, resultando na liberdade para consumir a maioria dos alimentos disponíveis durante o ano. Por exemplo, meninas entre a $1^{1}$ e e a $3^{\underline{a}}$ menstruação só podiam consumir carne de alguns pássaros; mulheres que pariram só comiam carne de tamanduá (Myrmecophagidae) até o recémnascido perder o cordão umbilical; durante a gravidez a mulher não consumia o bugio (Alouatta) ou mel das abelhas eiretxú. Os homens tinham seus momentos de restrição alimentar em algumas fases da vida, como nos rituais de passagem, na couvade e no sacrifício ritual, quando o matador executava o prisioneiro. Os pajés se submetiam constantemente a restrições alimentares. Por fim, as pessoas em busca de aguyjé (de perfeição, da plenitude humana) jejuavam e abstinham-se de carne. Em nível comunitário, notam-se momentos paralelos de liberdade e restrições alimentares em que todos os recursos obtidos conforme a época do ano circulavam e eram consumidos.

A dieta era centrada em plantas de agricultura e coleta, boa parte trazida da Amazônia. Ainda não há provas definitivas, mas já é possível dizer que os Guarani estão entre os primeiros a trazer para o Sul do Brasil várias espécies de plantas. Seu sistema de manejo agroflorestal certamente contribuiu para a ampliação da biodiversidade das comunidades vegetais das regiões onde se instalavam, uma vez que em vários pontos do Sul do Brasil há espécies nativas de outras regiões, como a própria Amazônia, CentroOeste do Brasil, Chaco, Andes e Pampa. O manejo era feito no interior de cada teko'á, o território de domínio de cada assentamento, entrecortado por trilhas que interligavam as aldeias e estas às roças, áreas de coleta, pesqueiros, áreas de caça, etc. Uma vez que as aldeias formavam conjuntos unidos politicamente por meio de alianças regionais, além dos laços de parentesco, havia um sistema de troca de mudas e sementes como ocorre entre vários povos como mesmo tipo de sistema agroflorestal, garantindo a disseminação de espécies entre os teko'á. Há vários casos de regiões continuamente ocupadas por mais de 1.500 anos, como se pode verificar na lista de datações da Tabela 6 , apontando para a longa duração dos teko'á.

Como outros povos amazônicos, conforme as fontes históricas e etnográficas, os Guarani também cultivavam em diversos locais, considerando as taxas variáveis de clima, umidade, tipos de solo, etc. Além da roça instalada em clareiras nas matas, plantavam: 1) junto às casas, dentro do 
TABELA 6

DATAÇÕES NÃO-CALIBRAdAS DOS Sítios ARQUEOLÓGICOS GUARANI

(A coluna " $\mathrm{n}$ - no mapa” indica onde estas informações estão situadas na Figura 7)

\begin{tabular}{|c|c|c|c|c|c|}
\hline Data AP & Sítio & Lab. № & Local & Fonte & $\begin{array}{c}\text { № } \\
\text { no mapa }\end{array}$ \\
\hline $1.870 \pm 100$ & $\mathrm{SP} / \mathrm{BA} / 7$ & SI 418 & Itaporanga & Brochado 1973 & 1 \\
\hline$* \pm 1.668$ & Ragil & FATEC & Iepê & Faccio 1998 & 7 \\
\hline$* \pm 1.260$ & Jango Luís & IEA & Angatuba & Pallestrini 1968/69 & 4 \\
\hline $1.195 \pm 80$ & $\mathrm{SP} / \mathrm{BA} / 7$ & SI 1009 & Itaporanga & Brochado 1973 & 1 \\
\hline $1.130 \pm 150$ & SP/AS/14 & SI 422 & Iepê & Chmyz 1968 & 7 \\
\hline$* \pm 1.093$ & Ragil 2 & FATEC & Iepê & Faccio 1998 & 7 \\
\hline$* \pm 1.076$ & Fonseca & IEA & Itapeva & Pallestrini 1968/69 & 3 \\
\hline$* 1.070 \pm 100$ & Camargo 2 & IF & Piraju & Morais 1988 & 2 \\
\hline$* \pm 1.020$ & Alves & IEA & Piraju & Pallestrini 1968/69 & 2 \\
\hline $980 \pm 100$ & SP/AS/14 & SI 709 & Iepê & Smithsonian & 7 \\
\hline $879 \pm 80$ & Nunes & IEA & Piraju & Pallestrini 1988 & 2 \\
\hline $850 \pm 150$ & $\mathrm{SP} / \mathrm{BA} / 7$ & SI 417 & Itaporanga & Brochado 1973 & 1 \\
\hline $760 \pm 50$ & $\mathrm{PR} / \mathrm{JA} / 2$ & SI 140 & Cambará & Chmyz 1967 & 5 \\
\hline$* \pm 755$ & Neves & FATEC & Iepê & Faccio 1998 & 7 \\
\hline $530 \pm 55$ & $\mathrm{PR} / \mathrm{NL} / 7$ & SI 6400 & Diamante do Norte & Chmyz e Chmyz 1986 & 8 \\
\hline$* \pm 520$ & Almeida & IEA & Tejupá & Pallestrini 1975 & 6 \\
\hline$* \pm 470$ & Almeida & IEA & Tejupá & Pallestrini 1975 & 6 \\
\hline $2.010 \pm 75$ & PR/FI/140 & SI 5028 & Foz do Iguaçu & Chmyz 1983 & 9 \\
\hline $1.625 \pm 60$ & PR/FI/118 & SI 5021 & Foz do Iguaçu & Chmyz 1983 & 9 \\
\hline $1.565 \pm 70$ & PR/FI/99 & SI 5019 & Foz do Iguaçu & Chmyz 1983 & 9 \\
\hline $1.395 \pm 60$ & PR/FI/142 & SI 5033 & Foz do Iguaçu & Chmyz 1983 & 9 \\
\hline $1.235 \pm 60$ & PR/FI/97 & SI 5016 & Foz do Iguaçu & Chmyz 1983 & 9 \\
\hline $760 \pm 40$ & $\mathrm{PR} / \mathrm{FO} / 4$ & SI 5039 & Guaíra & Chmyz 1983 & 9 \\
\hline $745 \pm 75$ & PR/FI/140 & SI 5027 & Foz do Iguaçu & Chmyz 1983 & 9 \\
\hline $700 \pm 55$ & PR/FI/112 & SI 5036 & Foz do Iguaçu & Chmyz 1983 & 9 \\
\hline $625 \pm 55$ & PR/FI/100 & SI 5020 & Foz do Iguaçu & Chmyz 1983 & 9 \\
\hline $600 \pm 60$ & PR/FI/103 & SI 5029 & Foz do Iguaçu & Chmyz 1983 & 9 \\
\hline $590 \pm 55$ & PR/FI/127 & SI 5024 & Foz do Iguaçu & Chmyz 1983 & 9 \\
\hline
\end{tabular}




\begin{tabular}{|c|c|c|c|c|c|}
\hline Data AP & Sítio & Lab. № & Local & Fonte & $\begin{array}{c}\text { № } \\
\text { no mapa }\end{array}$ \\
\hline $490 \pm 60$ & $\mathrm{PR} / \mathrm{FO} / 3$ & SI 5040 & Guaíra & Chmyz 1983 & 9 \\
\hline $475 \pm 45$ & $\mathrm{MT} / \mathrm{IV} / 1$ & SI 1017 & Bataiporã & Chmyz 1974 & 10 \\
\hline $415 \pm 75$ & PR/FI/104 & SI 5032 & Foz do Iguaçu & Chmyz 1983 & 9 \\
\hline $395 \pm 60$ & PR/FI/142 & SI 5034 & Foz do Iguaçu & Chmyz 1983 & 9 \\
\hline $340 \pm 60$ & PR/FI/1 18 & SI 5023 & Foz do Iguaçu & Chmyz 1983 & 9 \\
\hline $255 \pm 80$ & PR/FI/97 & SI 5017 & Foz do Iguaçu & Chmyz 1983 & 9 \\
\hline $260 \pm 70$ & MT/IV/1 & SI 1016 & Bataiporã & Chmyz 1974 & 10 \\
\hline $230 \pm 80$ & $\mathrm{PR} / \mathrm{FI} / 22$ & SI 5015 & Foz do Iguaçu & Chmyz 1983 & 9 \\
\hline $205 \pm 80$ & PR/FI/118 & SI 5022 & Foz do Iguaçu & Chmyz 1983 & 9 \\
\hline$? \pm 195$ & PR/FI/141 & SI 5031 & Foz do Iguaçu & Chmyz 1983 & 9 \\
\hline $190 \pm 75$ & PR/FI/98 & SI 5018 & Foz do Iguaçu & Chmyz 1983 & 9 \\
\hline $180 \pm 60$ & $\mathrm{MT} / \mathrm{IV} / 1$ & SI 1018 & Bataiporã & Chmyz 1974 & 10 \\
\hline $110 \pm 60$ & MT/IV/2 & SI 1019 & Bataiporã & Chmyz 1974 & 10 \\
\hline $85 \pm 75$ & PR/FI/104 & SI 5030 & Foz do Iguaçu & Chmyz 1983 & 9 \\
\hline $85 \pm 60$ & $\mathrm{PR} / \mathrm{FO} / 6$ & SI 5041 & Guaíra & Chmyz 1983 & 9 \\
\hline $500 \pm 45$ & PR/UV/16 & SI 1015 & União da Vitória & Chmyz 1977 & 12 \\
\hline $528 \pm 70$ & $\mathrm{PR} / \mathrm{CT} / 54$ & BA 22645 & Campo Largo & Chmyz 1995 & 13 \\
\hline $1.490 \pm 45$ & $\mathrm{PR} / \mathrm{FL} / 21$ & SI 1011 & Doutor Camargo & Brochado 1973 & 14 \\
\hline $1.380 \pm 150$ & José Vieira & Gsy 81 & Cidade Gaúcha & L.Emperaire 1962 & 16 \\
\hline $1.065 \pm 95$ & PR/ST/1 & SI 695 & Indianópolis & Brochado 1973 & 11 \\
\hline $610 \pm 120$ & $\mathrm{PR} / \mathrm{ST} / 1$ & SI 696 & Indianópolis & Brochado 1973 & 11 \\
\hline $590 \pm 70$ & $\mathrm{PR} / \mathrm{FL} / 15$ & SI 699 & Doutor Camargo & Brochado 1973 & 14 \\
\hline $560 \pm 60$ & $\mathrm{PR} / \mathrm{FL} / 23$ & SI 700 & Doutor Camargo & Brochado 1973 & 14 \\
\hline $540 \pm 60$ & $\mathrm{PR} / \mathrm{QN} / 2$ & SI 697 & Mirador & Brochado 1973 & 15 \\
\hline $470 \pm 100$ & $\mathrm{PR} / \mathrm{FL} / 5$ & SI 694 & Paraíso do Norte & Brochado 1973 & 15 \\
\hline $300 \pm 115$ & $\mathrm{PR} / \mathrm{FL} / 5$ & SI 693 & Paraíso do Norte & Brochado 1973 & 15 \\
\hline $135 \pm 120$ & PR/FL/13 & SI 698 & Doutor Camargo & Brochado 1973 & 14 \\
\hline $425 \pm 25$ & MS/IV/08 & FATEC & Anaurilândia & Kashimoto 1997 & 10 \\
\hline $239 \pm 10$ & MS/PR/13 & FATEC & Anaurilândia & Kashimoto 1997 & 10 \\
\hline $480 \pm 30$ & $\mathrm{MS} / \mathrm{PR} / 26$ & FATEC & Bataguaçu & Kashimoto 1997 & 10 \\
\hline $370 \pm 20$ & MS/PR/22 & FATEC & Bataguaçu & Kashimoto 1997 & 10 \\
\hline
\end{tabular}




\begin{tabular}{|c|c|c|c|c|c|}
\hline Data AP & Sítio & Lab. No & Local & Fonte & $\begin{array}{c}\text { № } \\
\text { no mapa }\end{array}$ \\
\hline $432 \pm 32$ & MS/PD/04 & FATEC & Anaurilândia & Kashimoto 1997 & 10 \\
\hline $240 \pm 30$ & MS/PD/06 & Gsy & Anaurilândia & Kashimoto 1997 & 10 \\
\hline $275 \pm 20$ & MS/PD/07 & FATEC & Anaurilândia & Kashimoto 1997 & 10 \\
\hline $625 \pm 40$ & $\mathrm{MS} / \mathrm{PR} / 35$ & FATEC & Bataguaçu & Kashimoto 1997 & 10 \\
\hline $580 \pm 40$ & MS/PR/39 & FATEC & Bataguaçu & Kashimoto 1997 & 10 \\
\hline $245 \pm 15$ & $\mathrm{MS} / \mathrm{PR} / 41$ & FATEC & Bataguaçu & Kashimoto 1997 & 10 \\
\hline $280 \pm 15$ & $\mathrm{MS} / \mathrm{PR} / 46$ & FATEC & Bataguaçu & Kashimoto 1997 & 10 \\
\hline $565 \pm 32$ & $\mathrm{MS} / \mathrm{PR} / 55$ & FATEC & Bataguaçu & Kashimoto 1997 & 10 \\
\hline $1.015 \pm 75$ & MS/PR/64 & Gsy & Brasilândia & Kashimoto 1997 & 10 \\
\hline $1.248 \pm 100$ & MS/PR/64 & FATEC & Brasilândia & Kashimoto 1997 & 10 \\
\hline $1.493 \pm 100$ & MS/PR/85 & FATEC & Brasilândia & Kashimoto 1997 & 10 \\
\hline $909 \pm 80$ & MS/PR/90 & FATEC & Três Lagoas & Kashimoto 1997 & 10 \\
\hline $480 \pm 30$ & MS/PR/98 & FATEC & Três Lagoas & Kashimoto 1997 & 10 \\
\hline $1.220 \pm 120$ & $\mathrm{RS} / \mathrm{VZ} / 4$ & SI 708 & Porto Lucena & Miller 1969 & 22 \\
\hline $920 \pm 70$ & no3/Panambi & $?$ & Oberá & Sempé e Caggiano 1995 & 22 \\
\hline $1.070 \pm 100$ & $\mathrm{SC} / \mathrm{U} / 69$ & SI 549 & Mondaí & Brochado 1973 & 18 \\
\hline $770 \pm 100$ & $\mathrm{SC} / \mathrm{U} / 53$ & SI 439 & Itapiranga & Brochado et al 1969 & 18 \\
\hline $620 \pm 80$ & $\mathrm{SC} / \mathrm{U} / 55$ & SI 550 & São Carlos & Brochado 1973 & 20 \\
\hline $590 \pm 100$ & $\mathrm{SC} / \mathrm{VP} / 38$ & SI 826 & Itá & Brochado 1973 & 17 \\
\hline $510 \pm 70$ & $\mathrm{SC} / \mathrm{U} / 55$ & SI 547 & São Carlos & Smithsonian & 20 \\
\hline $490 \pm 70$ & $\mathrm{SC} / \mathrm{VX} / 5$ & SI 548 & São Carlos & Brochado 1973 & 20 \\
\hline $900 \pm 50$ & $\mathrm{SC} / \mathrm{U} / 71$ & BA 118377 & Maximiliano de Almeida & Projeto Machadinho 1998 & 20 \\
\hline $530 \pm 70$ & $\mathrm{SC} / \mathrm{U} / 368$ & BA 118375 & Maximiliano de Almeida & Projeto Machadinho 1998 & 20 \\
\hline $420 \pm 60$ & $\mathrm{SC} / \mathrm{U} / 368$ & BA 118376 & Maximiliano de Almeida & Projeto Machadinho 1998 & 20 \\
\hline $250 \pm 90$ & $\mathrm{SC} / \mathrm{U} / 54$ & SI 546 & São Carlos & Brochado 1973 & 20 \\
\hline $225 \pm 55$ & $\mathrm{RS} / \mathrm{VZ} / 41$ & SI 701 & Tenente Portela & Brochado 1973 & 19 \\
\hline $215 \pm 105$ & $\mathrm{RS} / \mathrm{VZ} / 12$ & SI 702 & Porto Lucena & Brochado 1973 & 22 \\
\hline $550 \pm 70$ & Tapera & SI 244 & Florianópolis & Chmyz 1976 & 32 \\
\hline $1.800 \pm 100$ & $\mathrm{RS} / \mathrm{MJ} / 88$ & SI 2205 & Agudo & Brochado 1984 & 27 \\
\hline $1.475 \pm 80$ & $\mathrm{RS} / \mathrm{MJ} / 60$ & SI 2203 & Dona Francisca & Schmitz e Brochado 1972 & 27 \\
\hline
\end{tabular}




\begin{tabular}{|c|c|c|c|c|c|}
\hline Data AP & Sítio & Lab. № & Local & Fonte & $\begin{array}{c}\text { № } \\
\text { no mapa }\end{array}$ \\
\hline $1.255 \pm 100$ & $\mathrm{RS} / \mathrm{MJ} / 101$ & SI 2201 & Cachoeira & Schmitz e Brochado 1972 & 23 \\
\hline $1.261 \pm 140$ & Santa Tecla I & AC 1337 & Ituzaingó & Rodriguez 1996 & 32 \\
\hline $684 \pm 170$ & Santa Tecla I & AC 1338 & Ituzaingó & Rodriguez 1996 & 32 \\
\hline $430 \pm 50$ & Medina & LP-734 & Ituzaingó & Rodriguez 1996 & 32 \\
\hline $330 \pm 50$ & Medina & $\mathrm{LP}-750$ & Ituzaingó & Rodriguez 1996 & 32 \\
\hline $1.180 \pm 70$ & $\mathrm{RS} / \mathrm{MJ} / 60$ & SI 2204 & Dona Francisca & Schmitz e Brochado 1972 & 27 \\
\hline $905 \pm 95$ & $\mathrm{RS} / \mathrm{MJ} / 53 \mathrm{a}$ & SI 1196 & Nova Palma & Brochado 1973 & 27 \\
\hline $775 \pm 65$ & $\mathrm{RS} / \mathrm{MJ} / 98$ & SI 2198 & Cachoeira & Brochado 1984 & 23 \\
\hline $745115 \pm$ & $\mathrm{RS} / \mathrm{C} / 14$ & SI 1198 & São Sebastião do Caí & Ribeiro 1974 & 28 \\
\hline $695 \pm 55$ & $\mathrm{RS} / \mathrm{MJ} / 87$ & SI 2200 & Agudo & Brochado 1984 & 27 \\
\hline $800 \pm 40$ & $\mathrm{RS} / \mathrm{SM} / 7$ & SI 1003 & São Pedro do Sul & Brochado e Schmitz 1973 & 26 \\
\hline $605 \pm 40$ & $\mathrm{RS} / \mathrm{SM} / 7$ & SI 1002 & São Pedro do Sul & Brochado 1973 & 26 \\
\hline $530 \pm 100$ & $\mathrm{RS} / \mathrm{MJ} / 47 \mathrm{e}$ & SI 816 & Restinga Seca & Brochado 1973 & 24 \\
\hline $345 \pm 105$ & $\mathrm{RS} / \mathrm{MJ} / 50 \mathrm{a}$ & SI 818 & Santa Maria & Brochado 1973 & 25 \\
\hline $265 \pm 90$ & $\mathrm{RS} / \mathrm{MJ} / 71$ & SI 2199 & Dona Francisca & Brochado 1984 & 27 \\
\hline $220 \pm 85$ & $\mathrm{RS} / \mathrm{MJ} / 90$ & SI 2202 & Cachoeira & Brochado 1984 & 23 \\
\hline $190 \pm 85$ & $\mathrm{RS} / \mathrm{C} / 63$ & SI 1197 & Rio Branco & Ribeiro 1974 & 21 \\
\hline $130 \pm 105$ & $\mathrm{RS} / \mathrm{MJ} / 42 \mathrm{a}$ & SI 815 & Restinga Seca & Brochado 1984 & 24 \\
\hline $110 \pm 150$ & $\mathrm{RS} / \mathrm{MJ} / 5 \mathrm{Ob}$ & SI 817 & Santa Maria & Brochado 1984 & 25 \\
\hline $445 \pm 40$ & $\mathrm{RS} / \mathrm{CM} / 11$ & SI 6402 & Encruzilhada do Sul & Ribeiro et al. 1986 & 29 \\
\hline $540 \pm 60$ & $\mathrm{RS} / \mathrm{SR} / 342$ & BA 118375 & Guaíba & Hilbert 1999 & 29 \\
\hline $440 \pm 60$ & $\mathrm{RS} / \mathrm{SR} / 342$ & BA 118376 & Guaíba & Hilbert 1999 & 29 \\
\hline $1.070 \pm 110$ & $\mathrm{RS} / \mathrm{M} / 35$ & SI 413 & Osório & Brochado et al. 1968 & 31 \\
\hline $890 \pm 40$ & $\mathrm{RS} / \mathrm{RG} / 2$ & SI 1190 & Rio Grande & Naue 1973 & 30 \\
\hline $580 \pm 50$ & $\mathrm{RS} / 002 / 2$ & $?$ & Rio Grande & Hilbert et al. s.d. & 30 \\
\hline $510 \pm 60$ & $\mathrm{RS} / 002 / 2$ & $?$ & Rio Grande & Hilbert et al. s.d. & 30 \\
\hline $870 \pm 100$ & $\mathrm{RS} / \mathrm{M} / 35$ & SI 412 & Osório & Brochado 1973 & 31 \\
\hline $540 \pm 100$ & $\mathrm{RS} / \mathrm{M} / 16$ & SI 411 & Osório & Brochado 1973 & 31 \\
\hline $520 \pm 200$ & $\mathrm{RS} / \mathrm{M} / 16$ & SI 410 & Osório & Brochado 1973 & 31 \\
\hline
\end{tabular}

(* = termoluminescência $)$ 
perímetro da aldeia, formando pomares, hortas medicinais e de plantas para matéria-prima; 2) trilhas que ligam aldeias e roças entre si; 3 ) pequenas clareiras ao lado das trilhas; 4) locais onde encontravam clareiras naturais ou onde derrubavam árvores para coleta de madeira, mel ou insetos; 5) micronichos especiais; 6) criavam e ampliavam comunidades de uma espécie predominante, como os ervais de mate (Ilex), palmitais (Euterpe), pinheirais (Araucaria), entre várias outras.

A coleta de plantas era uma atividade complementar à agricultura. As plantas de coleta faziam parte do "pacote básico" que os Guarani carregavam consigo, ficando difícil distinguir a coleta da agricultura, uma vez que as áreas de roça em início de pousio eram o locus preferencial para inserir outras plantas úteis para alimentação, medicina e cultura material. O território de cada aldeia Guarani era pontilhado por roças e áreas de pousio com idades distintas. Após um determinado período, geralmente $10 \mathrm{ou}$ 15 anos, as antigas roças eram reativadas, uma vez que o solo havia recuperado seus índices de fertilidade. Em um estudo de caso, realizado na região do delta do Rio Jacuí, Rio Grande do Sul (Noelli 1993), verifiquei que havia mais de 300 itens vegetais que podiam compor a dieta Guarani, além das plantas de roça (Tabela 7).
Esta tabela permite verificar que a média mensal de ofertas de espécies vegetais/ fungos é elevada (deve-se considerar que a lista está incompleta). Além da disponibilidade in natura, os Guarani estocavam alimentos em silos subterrâneos, garantindo recursos extras, a exemplo das massas de pinhão estocadas em lugares úmidos.

Os Guarani cultivavam em suas roças uma média de 39 gêneros vegetais, subdivididos em pelo menos 159 cultivares (Noelli 1994). Em destaque, na Tabela 8, algumas variedades provedoras de carboidratos e proteínas.

Por sua vez, a obtenção de nutrientes e energia provindos de animais também era significativa. Os Guarani consumiam mamíferos, aves, peixes, répteis, anfíbios, moluscos e insetos, caçados, pescados ou coletados com simplicidade ou por meio de engenhosas armas e armadilhas, tanto de modo individual como coletivamente. Tudo indica que o acesso randômico à caça era empregado no cotidiano, enquanto o seletivo era usado em caçadas para o lazer, para presentear, abastecer as festas ou para obter espécies para fins rituais (como as mencionadas acima). As armadilhas de caça eram espalhadas em grande número pelas áreas de cultivo e pelas trilhas dos mamíferos, uma vez que a concentração de alimentos nas roças e demais áreas maneja-

\section{TABELA 7}

SAZONAlidade de Algumas Plantas de COLETA dos GuARANI

\begin{tabular}{l|c|c|c|c|c|c|c|c|c|c|c|c}
\hline \multicolumn{1}{c}{ Estação } & Verão & \multicolumn{1}{c}{ Inverno } \\
\hline Meses & Jan & Fev & Mar & Abr & Maio & Jun & Jul & Ago & Set & Out & Nov & Dez \\
\hline $\begin{array}{l}\text { Quantidade de espécies } \\
\text { frutíferas }\end{array}$ & 87 & 84 & 87 & 67 & 44 & 33 & 34 & 31 & 35 & 47 & 65 & 74 \\
\hline $\begin{array}{l}\text { Quantidade de espécies } \\
\text { de plantas de coleta: } \\
\begin{array}{l}\text { folha, raiz, broto, } \\
\text { rizoma, flores, sementes }\end{array}\end{array}$ & 67 & 67 & 67 & 66 & 64 & 64 & 64 & 64 & 66 & 66 & 67 & 66 \\
\hline $\begin{array}{l}\text { Quantidade de espécies } \\
\text { de fungos }\end{array}$ & 15 & 16 & 40 & 36 & 31 & 30 & 15 & 7 & 9 & 10 & 11 & 10 \\
\hline
\end{tabular}


TABELA 8

Lista de Algumas plantas da AGRicultura GUARANI

\begin{tabular}{|c|c|c|c|c|}
\hline \multirow{10}{*}{ Tuberosas } & Nome popular & Nome Guarani & Nome científico & № de cultivares \\
\hline & Mandioca & Mandi'o & Manihot esculenta & 24 \\
\hline & Batata doce & Jety & Ipomoea batatas & 21 \\
\hline & Batata "inglesa" & Maky & Solanum tuberosum & 1 \\
\hline & Cará & Kara & Dioscorea spp & 9 \\
\hline & & Mbakuku & Pachyrrhizus erosus & 3 \\
\hline & Mangarito & Tajao & Xanthosoma sagittifolium & 2 \\
\hline & Araruta & Akuti & Maranta arundinacea & 1 \\
\hline & Batatinha & Makyxi & Oxalis spp & 4 \\
\hline & & Mbery sai'yu & Canna glauca & 1 \\
\hline \multirow{10}{*}{ Graníferas } & Milho & Avati & Zea mais & 13 \\
\hline & Feijões & Kumanda & Phaseolus spp & 16 \\
\hline & Amaranto & Ka'aruru & Amaranthus spp & 4 \\
\hline & Quina & Ka'are & Chenopodium spp & $?$ \\
\hline & Amendoim & Manduvi & Arachis hypogaea & 7 \\
\hline & & Manduvirá & Lupinus spp & $?$ \\
\hline & Feijão Guandu & Kumanda yvyra'i & Cajanus spp & $?$ \\
\hline & & Kumanda cha'i & Strophostyles diversifolia & $?$ \\
\hline & Fava de rama & Kumanda usu & Canavalia spp & $?$ \\
\hline & Lágrima de N. Sra. & Mbaguero & Coix lacrima-jobi & 1 \\
\hline
\end{tabular}

das atraíam uma variada fauna. A maioria dos sítios arqueológicos está próxima de cursos d'água piscosos e, para pescar, conforme as fontes históricas, os Guarani dominavam pelo menos 11 técnicas distintas. As mais rentáveis, conforme o regime hídrico, eram: 1) nas corredeiras usavam o pari, armadilha com uma barreira que conduz os peixes para um cesto que os captura em quantidades controladas; 2) nas águas mansas espalhavam ictiotóxicos. Os grupos que viviam à beira-mar ou em cursos d'água que nele desaguavam utilizavam intensamente seus recursos, como as piracemas e a coleta intensa de moluscos. A Tabela 9 apresenta um exemplo de piracemas mensais no delta do Rio Jacuí, Rio Grande do Sul, mostrando o número de espécies que poderiam ser abundantemente pescadas nos seus afluentes.

\section{TABELA 9}

Piracemas mensais na Área do delta do Jacuí

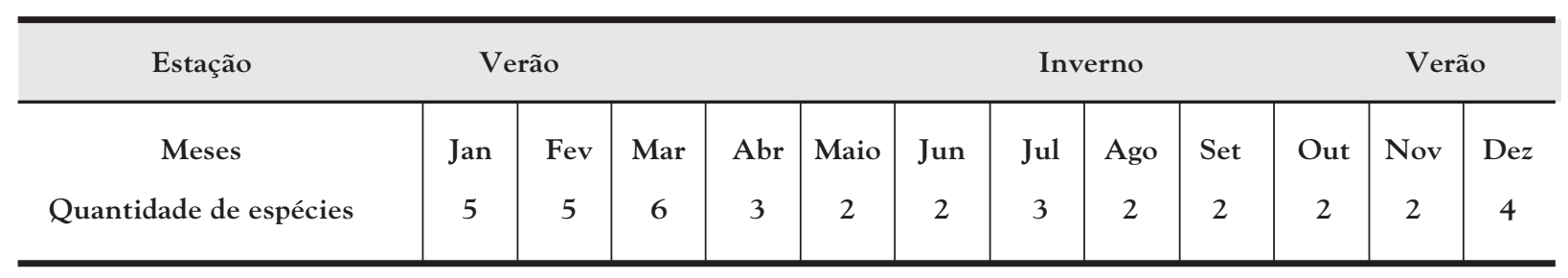


O consumo de insetos era outra prática que provia quantidades consideráveis de proteínas e energia. Várias espécies de larvas eram cultivadas intencionalmente, através da derrubada para apodrecimento de certas espécies arbóreas ou coletadas durante seus ciclos naturais (por exemplo: Pachymerus nucleorum, Caryobruchussp., Rhinostomus barbirostris, Rynchophorus palmarum, Acrocinus longimanus, Morpheis smerinta). Cupins (por exemplo: Cornitermes cumulans e Procornitermes striatus), formigas (por exemplo: Atta sexdens piriventris), abelhas e vespas (várias espécies) podiam ser consumidos tanto sob forma larval como adulta. Vários tipos de mel e partes das colméias eram consumidos, assim como as ceras eram intensamente utilizadas na produção da cultura material e outras finalidades, como a vedação.

O grande volume de plantas e animais está integrado a contextos materiais e nãomateriais sociologicamente ordenados, com indicadores materiais usados em constante reprodução ao longo de 2.000 anos. Parte da cultura material pode ser avaliada por meio de estudos lingüísticos e ergológicos, comparando dados dos Guarani com os de outros povos Tupi, visando identificar os índices de retenção de objetos e dos seus significados que foram reproduzidos desde a separação da matriz cultural Tupi.

Dentre os indicadores disponíveis escolhi a cerâmica como exemplo de análise, devido aos dados que mostram a continuidade entre os Guarani históricos e os registros arqueológicos de seus ascendentes, ressaltando-se a uniformidade lingüística e sua clara relação com a cultura material. O baixo índice de variabilidade nas classes de vasilhas reflete: 1) a capacidade de se adaptar os distintos ecótonos e tipos de sedimentos da Região Sul, reproduzindo o mesmo padrão tecnológico; 2) as mesmas funções em decorrência da manutenção dos padrões de abastecimento e dos hábitos dietários; 3) apesar da tendência de incorporar sistematicamente pessoas “não-Guarani”, das enormes dis- tâncias entre os extremos do território ocupado pelos Guarani e de 2.000 anos de História, verifica-se que havia uma rígida manutenção da reprodução das vasilhas cerâmicas; 4) que não houve interrupção na troca de informações entre as regiões Guarani.

A cerâmica Guarani possui características materiais constantes e variáveis formais estabelecidas dentro de um padrão estilístico rigidamente normatizado, submetido a regras tecnológicas reproduzidas na longa duração. Quando se abandonou a perspectiva de Meggers, que previa a análise de "cacos", despidos de significados sociológica e historicamente ordenados no interior da cultura Guarani, verificou-se que havia classes de vasilhas que possuíam determinadas formas, com características específicas para servir a funções definidas, embora seja possível que houvesse alguma variabilidade no uso cotidiano. O primeiro passo foi dado por Brochado, que identificou a taxonomia e a descrição de aspectos formais e funcionais em fontes históricas sobre os Guarani do século XVII (La Salvia e Brochado 1989; Brochado, Monticelli e Neuman 1990; Brochado e Monticelli 1994). O segundo passo de Brochado foi identificar esses atributos em coleções de vasilhas inteiras, através de cálculos de regressão linear para medir a proporção entre algumas medidas, o que permitiu definir as classes de vasilhas e constatar a existência de proporcionalidade entre suas formas. $\mathrm{O}$ terceiro foi definir a proporção entre as classes de um único sítio arqueológico. $\mathrm{O}$ quarto passo está se iniciando, com a utilização de processos físico-químicos para definir a função das vasilhas a partir de sua história térmica e dos vestígios orgânicos que nela são encontrados, para identificar elementos que atestem ou neguem a funcionalidade das classes de vasilhas identificadas através das informações históricas (Noelli, Trindade e Simão 1999; Noelli et al. 1999). Todavia é possível que se encontre variabilidade em termos de função, uma vez que vasilhas projetadas para um determinado fim po- 
diam ser utilizadas para outro.

Foram definidos dois conjuntos principais de classes de vasilhas, representados pelas utilizadas para transformar os ingredientes em alimentos (yapepós, naetás e cambuchis) e pelas tigelas usadas como pratos (ñáe) e tigelas de beber (cambuchi caguabã). Destacarei abaixo, dentre as 8 principais classes identificadas, as que possuíam função de panela, talha para conter cauim, pratos de comer e copos de beber cauim.

As panelas eram chamadas de yapepó, tendo uso principal sobre o fogo, para cozinhar e, secundário, como urna funerária. As dimensões atingem até $90 \mathrm{~cm}$ de altura e $100 \mathrm{~cm}$ de diâmetro na boca, e a capacidade pode ultrapassar os 120 litros. A base possui forma conoidal ou, quando de pequenas dimensões, arredondada. As paredes são mais ou menos infletidas, em geral fortemente convexas, formando um bojo pronunciado. A borda pode ser côncava, vertical, ligeiramente inclinada para dentro ou para fora. O tratamento de superfície mais freqüente externa é o corrugado, podendo ocorrer também alisamento, ungulado e escovado.

A vasilha para conter o cauim servido em festas era denominada cambuchí. É uma talha, com função principal para fermentar, armazenar e servir bebidas fermentadas alcoólicas e, secundária, como urna funerária. Não ia ao fogo, quando era pintada externamente. As dimensões variam entre 10 e $100 \mathrm{~cm}$ de altura e entre 18 e 70 $\mathrm{cm}$ de diâmetro na boca. Algumas ultrapassam o volume de 150 litros. A base é conoidal ou, mais raramente, arredondada. Seu perfil lembra vasilhas empilhadas e encaixadas umas às outras, com vários pontos de ângulos superpostos, sendo que o mais baixo forma um bojo pronunciado (carenado) e os seguintes reentrantes, criando até três secções convexas superpostas. O gargalo é elaborado, de perfil cambado, carenado ou reforçado, em cuja base se encontra um ponto de inflexão ou, mais comumente, um ponto de ângulo reentrante. A superfície externa é geralmente pintada na porção superior acima do seu maior di- âmetro acompanhando as inflexões e pontos de ângulo do perfil. A porção inferior é simplesmente alisada. Algumas podem ser corrugadas, unguladas, escovadas ou alisadas. São incluídas nesta classe também as vasilhas que, pela forma, não se distinguem dos yapepó. Entretanto, como são pintadas exteriormente não seriam utilizadas sobre o fogo.

As vasilhas com função de copo de beber cauim eram chamadas de cambuch caguabã. A altura é entre 4 e $20 \mathrm{~cm}$ e o diâmetro da boca entre 12 e 34 cm. Algumas podiam conter até 15 litros, mas a média contém de 3 a 6 litros. Quanto à forma podem ser: a) tigelas conoidais de contorno simples, abertas ou levemente restringidas; b) tigelas restringidas de contorno infletido; c) tigelas abertas e levemente restringidas, de contorno composto ou complexo, com um ponto de ângulo marcando a junção da base conoidal com a borda convexa, reta ou côncava; d) tigelas levemente restringidas, de contorno complexo, com dois pontos de ângulo, o mais alto deles reentrante, na base de uma borda mais ou menos elaborada. Quanto ao tratamento de superfície, as formas mais elaboradas são usualmente pintadas externamente, as mais simples são usualmente lisas, corrugadas ou unguladas, sendo raras as pintadas internamente. Quando pintadas, não iam ao fogo.

Os pratos de comer eram chamados de ñae e ñambé, possuindo medidas e características formais parecidas com as dos cambuchi caguabã, sendo mais usuais os conoidais de contorno simples, abertos ou levemente restringidos. O tratamento de superfície predominante é o corrugado, liso e ungulado, não devendo ocorrer os pintados pois estas vasilhas deviam ir ao fogo para aquecer ou reaquecer a comida.

Um aspecto que vimos constatando, mas que ainda está em processo de estudo, é a relação entre o tamanho dos pratos e copos e os seus usuários. Era muito comum, conforme informações históricas e etnográficas, familiares, afins ou aliados comerem em um mesmo prato, o que pode 
explicar a freqüência de pratos grandes nesta classe. Dentre os copos destacam-se alguns pintados, muito elaborados, com dimensões maiores que a média, podendo estar indicando pertencer a um líder ou a uma pessoa com prestígio, uma vez que os Guarani apreciavam e prestigiavam os "grandes bebedores".

A análise da frequiência das vasilhas Guarani em um assentamento da Lagoa Xambrê, Paraná, revelou que há uma quantidade maior de tigelas (543 vasilhas) em relação às demais classes de vasilhas (220) utilizadas normalmente para transformar alimentos, como claramente demonstram a Tabela 10 e a Figura 8.

Como se pode ver, predominam os pratos associados à "tigela 1" de contorno simples, e os copos associados com as "tigelas 2 e 3". As panelas e as talhas aparecem com freqüência menor, assim como os ñaetás, normalmente utilizados como caçarolas, mas que também podiam ser usados como prato coletivo. O que importa dos elementos sociologicamente contextualizados que encontramos é que eles são atributos analíticos consistentes para verificar e quantificar as constâncias na cerâmica Guarani, servindo de indicadores da reprodução cultural que podem ser localizados no espaço e no tempo. Observando as coleções cerâmicas da imensa área onde aparecem os sítios arqueológicos Guarani, é difícil encontrar uma porcentagem significativa de exemplares/sítio (>5\%) fora dos padrões identificados, mesmo quando se comparam sítios localizados a grandes distâncias entre si, numa área de eixo norte-sul entre Corumbá e Buenos Aires e de eixo lesteoeste entre o litoral sul brasileiro e o interior da Região Sul do Brasil e Paraguai. Pode-se concluir que os Guarani mantiveram sua cerâmica sob o mesmo estilo tecnológico, mantendo as taxonomias e as funções por cerca de 2.000 anos.

Para fins comparativos, visando detectar índices de retenção e reprodução de taxonomias e objetos com mesma função a longo prazo, também se faz uma comparação entre as terminologias cerâmicas de outras populações filiadas à família Tupi-guarani, como se pode verificar na Tabela 11 .

Embora os vocabulários e dicionários bilíngües sejam incompletos, e apesar de nem todas as línguas Tupi-guarani estarem dicionarizadas, verifica-se que a taxonomia e a função apresentam um índice elevado de retenção de atributos presentes desde a

\section{TABELA 10 \\ QuANTIDADE DAS ClASSES \\ DE VASILHAS}

\begin{tabular}{|c|c|}
\hline Classe de vasilha & Quantidade \\
\hline Yapepó & 50 \\
\hline Cambuchi & 20 \\
\hline Naetá & 150 \\
\hline Tigela 1 & 283 \\
\hline Tigela 2 & 129 \\
\hline Tigela 3 & 97 \\
\hline Tigela 4 & 34 \\
\hline
\end{tabular}

FIGURA 8

\section{FreQÜÊNCIA DAS ClASSES}

DE VASILHAS

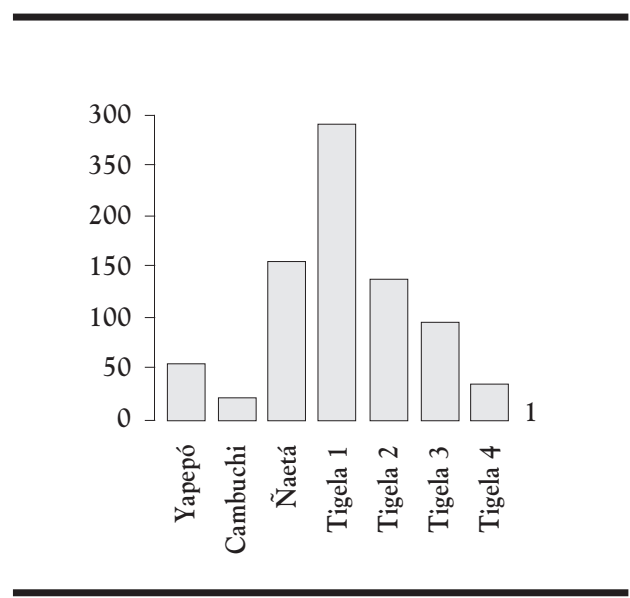


TABELA 11

COMPARAÇão ENTRE TAXONOMIA/FUNÇão DE VASILHAS CERÂMICAS

DE POVOS TUPI-GUARANI

\begin{tabular}{l|l|l|l|l}
\hline \multicolumn{1}{c}{ Povo/localização } & \multicolumn{1}{c}{ Panela } & \multicolumn{2}{c}{ Talha } & \\
\hline $\begin{array}{l}\text { Guarani, Sul do Br., } \\
\text { bacia do Prata }\end{array}$ & Yapepó & Cambuchi & Cambuchi caguabã & Naé, ñaembé \\
$\begin{array}{l}\text { Tupinambá, litoral Br. } \\
\text { até São Paulo }\end{array}$ & Nhaêpepô & Camuci & Caguaba & Nhaen \\
Asurini, Xingu & Japepaí & - & - & Ja’é \\
Kayabí, Xingu & Iapepó & - & - & - \\
Wirafed, Madeira & Yapepoí & - & - & - \\
Parintintin, Tapajós & Nhapepo & Kamambuí & - & Nae \\
Chiriguano, Bolívia & Yapepo & Cambuchi & Cagua & - \\
Apiacá, Tapajós & Nhepepô & - & - & - \\
Tembé, Gurupi & Zapêpo & Kamuti & - & - \\
Ka'apor, Gurupi & - & Kamuxi & - & \\
\hline
\end{tabular}

protolíngua. Este índice de retenção de atributos reforça a conclusão de que os Guarani reproduziram sua cerâmica desde que se separaram da família Tupi-guarani e desde que iniciaram o processo de conquista do Sul do Brasil, em um período que deve ultrapassar os 2.500 anos.

A distribuição das datações, como se pode ver na Tabela 6 , permite inferências sobre o processo de ocupação do espaço através do tempo. Pode-se perceber que os Guarani já estavam instalados nas bacias do Paranapanema, do Paraná, do Uruguai e do Jacuí ao redor de 2.000-1500 AP e, desde as datas mais antigas até as mais recentes, nota-se uma continuidade em cada uma destas áreas que só foi interrompida com a presença européia a partir dos séculos XVI e XVII. Como os dados são muito incompletos, não podemos acompanhar com clareza os processos das ocupações regionais, dos interflúvios e as relações com as outras populações que já ocupavam essas áreas. Também não podemos acompanhar os padrões locais de desdobramento dos assentamentos em novas unidades, bem como o tempo específico que durou a ocupação de cada um dos sítios arqueológicos. Dados históricos revelam que diversas aldeias Guarani no Paraguai ocupam os mesmos teko'as há mais de 150-200 anos, permitindo concluir que em situações semelhantes os antigos assentamentos podiam ser ocupados por períodos parecidos ou até mais prolongados.

\section{A PRESENCA EUROPÉIA}

As últimas populações que vieram ocupar o Sul do Brasil provêm da Europa, África e Ásia, em uma etapa que continua até o presente. Sua presença modificou 
rapidamente a composição e distribuição dos povos indígenas com uma velocidade distinta das mudanças ocorridas quando os Jê e os Guarani colonizaram a região. Em termos genéricos, é possível comparar esses dois maiores eventos de invasão e colonização de territórios e populações do Sul do Brasil. Se os Guarani e os Jê acabaram por eliminar ou assimilar as populações da tradições Umbu e Humaitá, os europeus fizeram parecido, eliminando e assimilando as populações Jê e Guarani, reduzindoas a grupos dispersos pelo Sul do Brasil, que na atualidade alcançam cerca de 24.000 pessoas, em franco processo de recuperação demográfica e de organização política em prol de sua autodeterminação e da recuperação de suas terras.

Os Xokleng e Kaingang, e os Guarani, invadiram e conquistaram territórios pertencentes às populações das tradições Umbu e Humaitá em um processo que durou cerca de 1.000 anos. Embora não saibamos ainda como se deram os contatos entre esses povos, é possível ter havido relações que iam das guerras às alianças políticas. Ao tempo da chegada dos europeus os Guarani e os Jê haviam praticamente eliminado ou reduzido drasticamente as populações Umbu e Humaitá da região do Planalto, sobrevivendo apenas as populações Umbu nas áreas de campo do Rio Grande do Sul e Uruguai.

A principal distinção da invasão e conquista européia é que ela foi mais rápida, tendo sido efetivada em menos de 350 anos. Embora isso deva ser explicado por diversos fatores, que vão da tecnologia e das novidades/modificações ecológicas às guerras e alianças específicas em cada região, os europeus contaram com um elemento inédito que auxiliou significativamente no processo de depopulação indígena: as epidemias (veja exemplo para outras regiões em: Crosby 1987; Reff, 1985; Watts, 1997; Cook, 1998). Varíola, gripe, sarampo, tifo, malária, tuberculose, pleurisia, caxumba, coqueluche, meningite e doenças venéreas agiam de forma isolada ou em conjunto, contribuindo para eliminar porções significativas das populações indígenas em cada área da Região Sul. As epidemias, paralelamente, contribuíam para desorganizar as estruturas sociais e a organização do trabalho em cada assentamento, bem como desestruturar as redes de alianças regionais, expondo as populações aos ataques militares europeus e de outros povos indígenas. Mesmo no caso dos povos indígenas que eram aliados e parceiros comerciais dos europeus, muitas vezes, acabaram sendo contaminadas e dizimadas pela ação das epidemias.

O essencial é que se deve considerar que a Região Sul não possuía áreas significativas desabitadas, como se pode verificar nas informações arqueológicas e nas fontes históricas do século XVI. Para os europeus conseguirem se estabelecer houve um prolongado e diversificado processo de contato, área por área, distinto a cada período e conjuntura histórica, variando também conforme as populações envolvidas. Isto ainda é superficialmente conhecido, havendo necessidade de estudos (excetuando-se o caso de São Paulo - cf. Monteiro 1994).

Durante o século XVI não houve uma ocupação efetiva da Região Sul por parte dos europeus, havendo basicamente a instalação de bases temporárias que serviam como ponto de comércio ou de partida de expedições em busca de cativos para os empreendimentos econômicos que eram desenvolvidos no litoral de São Vicente, Santos e, depois, Piratininga, bem como para a exportação de escravos para a Região Nordeste. As únicas instalações que podem ser consideradas como assentamentos coloniais neste século foram Ciudad Real, fundada em 1557 na foz do Rio Piquiri, e Vila Rica, construída no médio Rio Ivaí em 1576, ambas no noroeste do atual estado do Paraná. Fundadas pelos espanhóis, serviam como bases regionais para formação de encomiendas e para exploração econômica até sua destruição pelos paulistas na década de 1630 (Hemming 1978; Monteiro 1992b).

No litoral de Santa Catarina, até cerca de 1550, os espanhóis mantiveram alguns 
pontos de abastecimento e reparos náuticos, sempre relacionados com alianças comerciais baseadas na troca de mercadorias por alimentos e matérias-primas realizada com grupos Guarani. Eles não conseguiram ser transformados em assentamentos permanentes devido à constante pressão dos paulistas e às epidemias, que reduziram drasticamente seus grupos aliados na região da Ilha de Santa Catarina e baías próximas.

No século XVII, a partir de 1610, os jesuítas fundaram 13 missões religiosas nas bacias dos rios Paranapanema, Tibagi, Ivaí e Paraná, aldeando milhares de Guarani e pequenos grupos Kaingang. A partirde 1626, no noroeste do atual Rio Grande do Sul, foram fundadas mais 18 missões. Ambos os empreendimentos foram encerrados entre 1632 e 1641, devido aos ataques bandeirantes (Melià 1986; Monteiro 1994). No litoral atlântico as tentativas de instalação de missões religiosas não tiveram o mesmo sucesso, sendo abandonadas por volta de 1626 devido ao constante ataque dos portugueses provenientes de São Vicente.

O final do século XVII e o século XVIII foram sucessivamente marcados pela ocupação do litoral atlântico, do Paraná ao Rio Grande do Sul, por súditos da Coroa portuguesa, primeiro em pontos estratégicos, como as baías de Paranaguá, São Francisco do Sul, Desterro (Florianópolis) e o porto de Laguna. Destes pontos foram sendo abertos caminhos em direção ao interior, com a instalação nas áreas de Curitiba, Lages, Guarapuava, construindo as redes de caminhos em busca do gado no Rio Grande do Sul.

O tamanho e a proporção entre as populações indígenas mudaram drasticamente. No século XVI e até a segunda metade do século XVII os Guarani formavam o conjunto populacional mais numeroso, ocupando a maior área da Região Sul, até entrarem em processo de declínio demográfico. Embora tenham conseguido manter uma população nas reduções jesuíticas acima da média de 80.000 pessoas até 1750-60, a população não reduzida declinou até sobrarem dois bolsões principais, um no Paraguai e outro no sul do Mato Grosso do Sul, e pequenas comunidades isoladas distribuídas por toda a região. A partir da segunda metade do século XVII até o princípio do século $\mathrm{XX}$, os povos Kaingang e Xokleng tornaram-se a maior frente demográfica ao avanço colonial português e, depois, ao avanço brasileiro. É possível que nesse período a população tenha aumentado em relação ao seu tamanho no século XVI, em parte devido à ocupação dos imensos territórios liberados pelos Guarani. Nos primeiros 150 anos da presença européia houve um sucessivo processo de redução demográfica Guarani, esvaziando o interior e o litoral, do Paraná ao Rio Grande do Sul, o que provocou uma remodelação na distribuição dos povos Kaingang e Xokleng. Os Kaingang se expandiram sobre as bacias do Tibagi, Ivaí e Piquiri, enquanto os Xokleng retornaram ao litoral, em pontos restritos, retardando o avanço colonial português. A partir do final do século XVII os Guarani, aldeados em missões jesuíticas, reocuparam o noroeste do Rio Grande do Sul, fundando sete povoações, com uma série de zonas satélites de produção de erva-mate e da pecuária diversificada (bovina, muar, cavalar) que acabaram tendo presença destacada no comércio da Bacia Platina, até a destruição das missões e expulsão dos jesuítas a partir de 1750. O final do século XVIII e o século XIX foram marcados pelo avanço contínuo dos portugueses, tornados brasileiros a partir de 1822, e pela contínua redução das populações indígenas, que passaram a ser atacadas por grupos de extermínio financiados pelos governos provinciais. A partir do início do século XIX começaram a ser introduzidos imigrantes alemães, italianos e de outras nacionalidades européias, que foram sendo instalados nas fronteiras com os povos indígenas. Esses imigrantes também constituíram tropas de extermínio, conhecidos como "bugreiros", que atuaram até a década de 20 do século XX (Santos 1973). Mesmo as frentes de colonização mais recentes, que remontam a 1950, também exterminaram sub- 
repticiamente ou explicitamente grupos não-confinados, como os Xetá do Paraná (Silva 1998). Por fim, no século XX, com a fundação do Serviço de Proteção ao Índio (SPI, atual Funai), passou a ser estabelecida a política de confinar os povos indígenas em reservas restritas, que persistem até a atualidade (Lima 1995).

\section{CONSIDERAÇOESS FINAIS}

A construção da história das ocupações humanas no Sul do Brasil está ainda no início, apesar dos seus 128 anos. Faz pouco que a fase prospectiva se encerrou, e que se começou a reavaliar e repensar criticamente as abordagens, os métodos, as idéias e as conclusões que perduraram nos últimos 35 anos. O provincianismo, o paroquialismo e o compadrio dominantes estão derruindo lentamente, cedendo lugar a perspectivas mais afins com o cosmopolitismo e o profissionalismo que caracterizam a arqueologia, uma disciplina internacional e interdisciplinar por excelência. Agora tentamos construir relações imprescindíveis que foram ignoradas no início de fase profissional, desde 1954. Estamos vivenciando os primeiros anos do resto da longa vida por vir da pesquisa arqueológica no Sul do Brasil, procurando estabelecer sólidas relações com disciplinas afins, como a antropologia, a história e a lingüística, bem como aprofundar as relações com as ciências naturais.

Na atualidade sete desafios são prementes para a região, considerando as sugestões propostas há uma década por Neves (1988): 1) intensificar as abordagens regionais, com o objetivo geral de verificar diferenças e semelhanças, continuidades, descontinuidades e mudanças no interior das tradições arqueológicas estabelecidas; 2) adotar os aspectos positivos das abordagens processualista e pós-processualista, tanto os em voga quanto os que estão em curso de desenvolvimento; 3) contribuir efetivamente para a proteção do patrimônio arqueológico, que vem sofrendo baixas cada vez mais significativas; 4) ampliar a formação e a qualificação de novos arqueólogos, bem como estabelecer estratégias para abertura de novos postos de trabalho nas universidades e demais instituições culturais públicas e privadas; 5) repensar seriamente a ética e o papel científico da "arqueologia de contrato"; 6) criar um canal de comunicação com os povos indígenas do Sul, que necessitam de informações para suas demandas em prol da autodeterminação e da luta para reaver terras espoliadas pela nação brasileira; 7) trabalhar pela construção de um sistema de comunicação que transmita de modo didático as informações e as pesquisas arqueológicas.

Toda a pesquisa e todos os esforços científicos devem convergir para uma linguagem que ultrapasse a comunidade de arqueólogos, chegando limpidamente aos não-acadêmicos. Isso é fundamental, pois os arqueólogos que dominaram o cenário acadêmico nos últimos 35 anos estabeleceram um distanciamento do público através de esquemas interpretativos ininteligíveis e criptográficos. Mesmo colegas de outras disciplinas, como da antropologia e da história, não conseguem ou não tiveram interesse em compreender a linguagem cifrada que foi utilizada, compreensível só para alguns iniciados. A disseminação de informações inteligíveis e didáticas é um ponto-chave para o futuro do patrimônio arqueológico, pois “o que não é visto não é lembrado".

Enfim, a pesquisa sobre a ocupação humana do Sul do Brasil é um campo científico repleto de desafios, com muito ainda por ser feito. A esperança reside no papel que os arqueólogos irão escolher, modificando a postura geral que padronizou o desempenho da primeira geração, dando espaço para novas idéias e procedimentos, bem como abrindo caminho para a formação e o estabelecimento de mais arqueólogos. Somente dessa maneira é que será possível criar as condições necessárias para o desenvolvimento efetivo da arqueologia e para o (re)conhecimento das populações que ali viveram nos últimos doze milênios. 


\section{REFERÊNCIAS BIBLIOGRÁFICAS}

Amaral, M. M. V. 1995 As oficinas líticas da ilha de Santa Catarina. Dissertação de Mestrado em Arqueologia, Pontifícia Universidade Católica do Rio Grande do Sul, Porto Alegre.

Balée, W. 1988 Cultura na vegetação da Amazônia brasileira. In: Neves, W.A. (org.), Biologia e Ecologia Humana na Amazônia: avaliação e perspectivas, pp. 95-109. Museu Paraense Emílio Goeld/SCT/CNPq, Belém.

1994 Footprints in the forest. Columbia University Press, New York.

Bandeira, D. R. 1992 Mudança na estratégia de subsistência. 0 sítio arqueológico Enseada I - Um estudo de caso. Dissertação de Mestrado em Antropologia, Universidade Federal de Santa Catarina, Florianópolis.

Barreto, C. 1998. Brazilian archaeology from a Brazilian perspective. Antiquity, 72(277): 573-81.

Becker, I. I. B. 1984 El índio y la colonización. Charruas y Minuanes. Pesquisas, antropologia, 37: 1-286.

Brochado, J. P. 1973 Migraciones que difundieron la tradición alfarera Tupiguarani. Relaciones, n. s., 7: 7-39.

1984 An ecological model of the spread of pottery and agriculture into Easterno South America. Tese de Doutorado em Antropologia, University of Illinois at Urbana-Champaign.

1989 A expansão dos Tupi e da cerâmica da tradição policrômica amazônica. Dédalo, 27: 65-82.

1990 Um modelo de difusão da cerâmica e da agricultura no leste da América do Sul. Anais do I

Simpósio de Pré-História do Nordeste Brasileiro. Clío, série arqueológica, 4: 85-8.

Brochado, J. P. e Lathrap, D. 1982 Amazônia. Manuscrito inédito.

Brochado, J. P.; Monticelli, G. e Neumann, E. 1990 Analogia etnográfica na reconstrução gráfica das vasilhas Guarani arqueológicas. Veritas, 35 (140): 727-43.

Brochado, J. P. e Monticelli, G. 1994 Regras práticas na reconstrução gráfica da cerâmica Guarani por comparação com vasilhas inteiras. Estudos Ibero-Americanos, 20 (2): 107-18.

Brochado, J. P. e Schmitz, P. I. 1973 Aleros y cuevas com petroglifos e industria lítica de la escarpa del Planalto Meridional en Rio Grande do Sul, Brasil. Anales de Arqueología y Etnología, 27-28: 39-66.

Brochado, J. P. et al. 1969 Arqueologia Brasileira em 1968. Museu Paraense Emílio Goeldi, Belém.

Brücher, H. 1988 Difusión transamericana de vegetales útiles del Neotropico en la época Pre-colombiana. In: Posey, D. A. e Overal, W. L. (eds.), Ethnobiology: implications and applications, v. 1: pp. 265-84. Museu Paraense Emílio Goeldi/SCT/CNPq.

Bryan, A. L. 1965 Paleoamerican Prehistory. Occasional Papers of the Idaho State University Museum, 16. Pocatello, Idaho State University.

Chmyz, I. 1967 Dados parciais sobre a arqueologia do vale do rio Parapanema. Pronapa, 1. Publicações Avulsas do Museu Paraense Emílio Goeldi, 6: 59-73.

. 1968 Considerações sobre duas novas tradições ceramistas arqueológicas no Estado do Paraná.

Pesquisas, antropologia, 18: 115-25.

1969. Dados parciais sobre a arqueologia do vale do rio Ivaí. Pronapa, 2. Publicações Avulsas do Museu Paraense Emílio Goeldi, 10: 95-118.

1974 Dados arqueológicos do baixo rio Paranapanema e do alto rio Paraná. Pronapa, 5. Publicações Avulsas do Museu Paraense Emílio Goeldi, 26: 67-90.

1976 A ocupação do litoral dos Estados do Paraná e Santa Catarina por povos ceramistas. Estudos Brasileiros, 1: 7-43.

1977 Pesquisas paleoetnográficas efetuadas no vale do rio Paranapanema, Paraná - São Paulo.

Boletim de Psicologia e Antropologia, 5: 1-248.

. 1978 Terceiro Relatório do Projeto Arqueológico Itaipu. Itaipu/Iphan, Curitiba.

1981 Relatório das pesquisas arqueológicas realizadas na área da usina hidrelétrica Salto Santiago

(1979-1980). Eletrosul/Iphan, Curitiba/Florianópolis.

1983 Sétimo Relatório do Projeto Arqueológico Itaipu. Itaipu/Iphan, Curitiba.

. 1995 Arqueologia de Curitiba. Boletim Informativo da Casa Romário Martins, 21 (105): 5-54.

Chmyz, I. e Chmyz, J. C. 1986 Datações radiométricas em áreas de salvamento arqueológico no Estado do Paraná. Arqueologia. Revista do Centro de Estudos e Pesquisas Arqueológicas, 5: 69-77.

Cocivolo, J. A. e Neves, W. A. 1988-89 Afinidades biológicas entre las poblaciones prehistóricas del litoral del Brasil y de Argentina. Primera aproximación. Relaciones, n. s., 17 (2): 31-56.

Cook, N. D. 1998 Born to die. Disease and New World conquest, 1492-1650. Cambridge University Press, Cambridge. 
Consens, M. 1995 Evaluación de un sítio com grabados rupestres. H-TA-CR I, Colonia Rubio, Salto, Uruguay. In: Consens, M. et al. (coords.), Arqueología en el Uruguay. Anales del VIII Congreso Nacional de Arqueología Uruguaya, pp. 172-92. Montevidéo.

1999 História de uma desconstrução. Análise tecno-tipológica de indústrias líticas como recurso interpretativo sobre aspectos da diferença cultural. Revista do CEPA, 23 (29): 64-72.

Crosby, A. W. 1987 Imperialismo ecológico. Companhia das Letras, São Paulo.

Davis, I. 1966 Proto Jê phonology. Estudos Lingüísticos. Revista Brasileira de Lingüística Teórica e Aplicada, 1 (2): 10-24.

1968 Some Macro-Jê relationships. International Journal of American Linguistics, 34: 42-7.

De Blasis, P. A. 1996 Bairro da Serra em três tempos. Arqueologia, uso do espaço regional e continuidade cultural no médio vale do Ribeira. Tese de Doutorado em Arqueologia, Universidade de São Paulo, São Paulo.

Dias, A. S. 1994 Repensando a tradição Umbu a partir de um estudo de caso. Dissertação de Mestrado em Arqueologia, Pontifícia Universidade Católica do Rio Grande do Sul, Porto Alegre.

1995 Um projeto para a arqueologia brasileira: breve histórico da implementação do Pronapa. Revista do CEPA, 19(22): 25-39.

1999 Painel dos últimos trinta anos de pesquisas arqueológicas dos caçadores-coletores do Sul do Brasil. Revista do CEPA, 23(29): 52-9.

Ehrenreich, P. 1891 Die Einteilung und Verbreitung der Völkerstämme Brasiliens nach dem gegenwärtigen Stande unserer Kenntnisse. Petermanns Mitteilungen aus Justus Perthes' geographischer Anstalt, 37: 81-9, 114-24.

Evans, C. e Meggers, B. 1965 Guia para prospecção arqueológica no Brasil. Museu Paraense Emílio Goeldi, Belém.

Faccio, N. 1998 Arqueologia do cenário das ocupações horticultoras da Capivara, Baixo Paranapanema - SP. Tese de Doutorado em Arqueologia, Universidade de São Paulo, São Paulo.

Funari, P. P. A. 1989 Brazilian Archaeology and World Archaeology: some remarks. World Archaeology Bulletin, 3: 60-8. 1991 Archaeology in Brazil: politics and scholarship at a crossroads. World Archaeology Bulletin, 5:

$122-32$

1994. Arqueologia brasileira - visão geral e reavaliação. Revista de História da Arte e Arqueologia, 1:

23-41.

1995 Mixed features of archaeological theory in Brazil. In: Peter, J. U. (ed.), Theory in Archaeology, pp. 236-50. Routledge, London.

1997 Archaelogy, History and Historical Archaeology in South America. International Journal of Historical Archaeology, 1 (3): 189-206.

1999 A importância da teoria arqueológica internacional para a Arqueologia Sul-Americana: o caso

brasileiro. In: Funari, P. P.; Neves, E. G. e Podgorny, I. (orgs.), Teoria arqueológica na América do Sul. MAE/USP, São Paulo.

Garlet, I. J. e Soares, A. L. 1998 Cachimbos Mbyá-Guarani: aportes etnográficos para uma Arqueologia Guarani. In: Funari, P. P. (org.), Cultura material e Arqueologia Histórica. pp. 250-74. IFCH-Unicamp, Campinas.

Gonçalves, J. H. 1996 História Regional e ideologias: em torno de algumas corografias políticas do norte paranaense - 1930-1980. Dissertação de Mestrado em História, Universidade Federal do Paraná, Curitiba.

González, E. R. 1998 Regional pottery-making groups in Southern Brazil. Antiquity, 72(277): 616-24.

Hemming, J. 1978 Red gold. The conquest of the brazilian indians. Cambridge University Press, Cambridge. Hicks, D. 1966 The Kaingang and Aweikoma: a cultural contrast. Anthropos, 61: 839-46.

. 1971 The comparative analysis of the Kaingang and Aweikoma relationships terminologies (Brazil). Anthropos, 66: 931-5.

Hilbert, K. 1991 Aspectos de la Arqueología en el Uruguay. Philipp von Zabern, Mainz.

1999 Arqueologia Guarani na região de Guaíba - RS. Resumos da X Reunião Científica da Sociedade de Arqueologia Brasileira. Recife.

Hilbert, K. et al. s.d. Fazenda Soares: um sítio de ocupação Guarani na planície costeira do Rio Grande do Sul. Apresentado na IX Reunião Científica da Sociedade de Arqueologia Brasileira (1997). Rio de Janeiro.

Hill, K. et al. 1995 Aché life History. The Ecology and Demography of a foraging people. Aldine, Chicago. Hoeltz, S. 1997 Artesãos e artefatos pré-históricos do vale do rio Pardo. Edunisc, Santa Cruz do Sul.

. 1999 Estudo de coleç̃oes líticas: limites e possibilidades. Revista do CEPA, 23(29): 60-3.

Jacobus, A. L. 1991 Alimentos utilizados pelo homem pré-histórico. Arqueologia do Rio Grande do Sul, Documentos, 5: 161-78.

1998 As pesquisas em Arqueologia Histórica na Bacia do Prata. Revista do CEPA, 22 (27-28): 33-62. 
1999. A arqueofauna na Tradição Umbu. Revista do CEPA, 23(29): 88-93.

Kashimoto, E. M. 1997 Variáveis ambientais e arqueológicas no alto Paraná. Tese de Doutorado em Arqueologia, Universidade de São Paulo, São Paulo.

Kipnis, R. et al. (org.). Bibliografia da Arqueologia Brasileira. Arquivos do Museu de História Natural, 15-16: 1-312. Kern, A. A. 1981 Le précéramique du plateau sud-brésilien. Tese de Doutorado em Arqueologia, École des Hautes Études en Sciences Sociales, Paris.

1981/1982. Variáveis para a definição e caracterização das tradições pré-cerâmicas Umbu e Humaitá. Arquivos do Museu de História Natural, 6-7: 99-108.

1991 a Paleopaisagens e povoamento do Rio Grande do Sul. In: Kern, A. (org.), Arqueologia PréHistórica do Rio Grande do Sul, pp. 13-62. Mercado Aberto, Porto Alegre.

. 1991 b Origens da ocupação pré-histórica do Rio Grande do Sul na transição Pleistoceno-Holoceno. In:

Kern, A. A., (org.), Arqueologia Pré-Histórica do Rio Grande do Sul, pp. 89-102. Mercado Aberto, Porto Alegre. . 1991c Grupos pré-históricos de caçadores-coletores da floresta subtropical. In: Kern, A. (org.), Arqueologia Pré-Histórica do Rio Grande do Sul. pp. 135-66. Mercado Aberto, Porto Alegre.

(org.). 1991d Arqueologia Pré-Histórica do Rio Grande do Sul. Mercado Aberto, Porto Alegre.

Laming-Emperaire, A. 1962 Travaux archéologiques en Amérique du Sud. Objets et Mondes, 2(3): 149-64.

1968 Missions archéologiques françaises au Chili Austral et Brésil Meridional: datations de quelques sites par le radiocarbone. Journal de la Société des Americanistes, n. s., 57: 77-99.

Landa, B. 1995 A mulher Guarani: atividades e cultura material. Dissertação de Mestrado em Arqueologia, Pontifícia Universidade Católica do Rio Grande do Sul, Porto Alegre.

Landa, B. e Noelli, F. S. 1996 As receitas culinárias Guarani como base para a dieta do grupo. Histórica, 2: 163-72. Lathrap, D. 1970 The upper Amazon. Thames e Hudson, London.

1977 Our father the cayman, our mother the gourd: Spinden revisited or a unitary model for the emergence of agriculture in the New World. In: Reed, C. (ed.), Origins of Agriculture, pp. 713-51. The Hague, Mouton. Lavina, R. 1994 Os Xokleng de Santa Catarina: uma etno-história e sugestões para os arqueólogos. Dissertação de Mestrado em História, Universidade do Vale do Rio dos Sinos, São Leopoldo.

Lee, R. B. 1968 What hunters do for a living, or, how to make out on scarce resources. In: Lee, R. B. e De Vore, I. (eds.), Man the hunter, pp. 30-48. Aldine, Chicago.

Lima, A. C. S. 1995 Um grande cerco de paz. Vozes, Petropólis.

Lima, T. A. 1997 Teoria e método na Arqueologia brasileira: Avaliação e perspectivas. Trabalho apresentado no IX Congresso da Sociedade de Arqueologia Brasileira. Rio de Janeiro.

Lopez, J. M. L 1999 La construcción de túmulos entre cazadores-coletores complejos del Este de Uruguay. Fronteiras, 2(4): 297-310.

s.d. Investigaciones arqueológicas en "cerritos" (mounds) de la cuenca de la Laguna Merín. Latin American Antiquity (no prelo).

Martius, C. P. 1867 Beiträge zur Ethnographie uns Sprachenkunde Südamerika's, zumals Brasiliens. Friedrich Fischer, Leipzig.

Masi, M. A. 1990 Escavações arqueológicas do Pe. Alfredo Rohr S.J. 0 assentamento da Armação do Sul, SC. Dissertação de Mestrado em História, Universidade do Vale do Rio dos Sinos, São Leopoldo.

Maybury-Lewis, D. (ed.). 1979 Dialetical societies: the Gê and Bororo of Central Brazil. Harvard University Press, Cambridge.

Meggers, B. 1955 The coming of age of American Archaeology. In. Newman, M. T. (ed.), New Interpretations of aboriginal American Culture History, pp. 116-29. $7^{\text {th }}$ Anniversary of the Anthropological Society of Washington, Washington.

Meggers, B. e Evans, C. 1977 Lowland South America and the Antilles. In: Jennings, J. D. (ed.), Ancient Native Americans, pp. 543-91. W. H. Freeman e Comp., San Francisco.

Melià, B. 1986 El Guaraní conquistado y reducido. CEAUC, Asunción.

Melià, B.; Saul, M. V. A. e Muraro, V. 19870 Guarani. Uma bibliografia etnológica. Fundação Nacional próMemória/ Fundames, Santo Ângelo.

Melià, B. e Nagel, L. M. 1995. Guaraníes y jesuítas en tiempo de Misiones. Cepag/URI, Asunción.

Menghín, 0. 1957 El poblamiento prehistórico de Misiones. Anales de Arqueología y Etnología, 12: 19-40.

Métraux, A. 1928 La Civilisation Matérielle des Tribus Tupi-guarani. Librarie Orientaliste, Paris.

1946 The Caingang. In: Steward, J. (ed.), Handbook of South American Indians, pp. 1: 445-75. 
Smithsonian Institution, Washington.

Milder, S. 1994 A fase Ibicuí: uma revisão arqueológica, cronológica e estratigráfica. Dissertação de Mestrado em Arqueologia, Pontifícia Universidade Católica do Rio Grande do Sul, Porto Alegre.

1995 Uma breve análise da fase arqueológica Ibicuí. Revista do CEPA, 27 (22): 41-63.

1999 Caçadores coletores: a problemática arqueológica sobre os primeiros povoadores do Rio Grande do Sul. In: Quevedo, J. (org.), Rio Grande do Sul. 4 séculos de história, pp. 5-59. Martins Livreiro, Porto Alegre.

Miller, E. 1967 Pesquisas arqueológicas efetuadas no nordeste do Rio Grande do Sul. Pronapa, 1. Publicações Avulsas do Museu Paraense Emílio Goeldi, 6: 15-38.

. 1987 Pesquisas arqueológicas paleoindígenas no Brasil ocidental. Estudíos Atacameños, 8: 37-61.

Miller Jr., T. 1978 Tecnologia cerâmica dos Caingang paulistas. Arquivos do Museu Paranaense, Etnologia, 2: 1-51.

Montardo, D. L. 1995 Práticas funerárias das populações pré-coloniais e suas evidências arqueológicas (reflexões iniciais). Dissertação de Mestrado em Arqueologia, Pontifícia Universidade Católica do Rio Grande do Sul, Porto Alegre.

Montardo, D. L. e Noelli, F. S. 1996 Sugestões para o estudo de enterramentos Guarani. Anais da VIII Reunião Cientifica da Sociedade de Arqueologia Brasileira, 1 (1): 491-502.

Monteiro, J. M. 1992a Tupis, Tapuias e a História de São Paulo. Novos Estudos Cebrap, 34: 125-35.

Monteiro, J.M. 1992b. Os Guarani e a História do Brasil Meridional, séculos XVI-XVII. In: Cunha, M. C. (org). História dos Índios no Brasil, pp. 475-98. Companhia das Letras/Fapesp/SMC, São Paulo, .

1994 Negros da terra. Companhia das Letras, São Paulo.

Monticelli, G. 1995 Vasilhas cerâmicas Guarani. Um resgate da memória entre os Mbyá. Dissertação de Mestrado em Arqueologia, Pontifícia Universidade Católica do Rio Grande do Sul, Porto Alegre.

Morais, J. L. 1988 Estudo do sítio Camargo 2 - Pirajú, SP. Ensaio tecnotipológico de sua indústria lítica. Revista do Museu Paulista, n.s., 33: 41-128.

Mota, L. T. 1994a As guerras dos índios Kaingang: a história épica dos índios Kaingang no Paraná (1769-1924). Eduem, Maringá.

1994b A construção do vazio demográfico e a retirada da presença indígena da história social do Paraná. Pós-História, 4: 123-7.

19980 aço, a cruz e a terra: índios e brancos no Paraná Provincial (1853-1889). Tese de Doutorado em História, Universidade Estadual Paulista, Assis.

Mota, L. T. et al. 1996 Pãri: armadilhas de pesca utilizadas pelos índios Kaingang no Sul do Brasil. Universidade e Sociedade, 15: 21-5.

Munford et al. 1995 Human cranial variation in South America: implications for the settlement of the New World. Revista Brasileira de Genética, 18(40): 673-88.

Naue, G. Dados sobre 0 estudo dos cerritos na área meridional da Lagoa dos Patos, Rio Grande, RS. Veritas, 71 (73): 246-69.

Neves, E. G. 1995 Village fissioning in a Amazonia: a critique of monocausal determinism. Revista do Museu de Arqueologia e Etnologia, 5: 195-209.

1998 Twenty years of Amazonian Archaeology in Brazil (1977-1997). Antiquity, 72(277): 625-32

Neves, W. A. 1984 Paleogenética dos grupos Pré-Históricos do litoral Sul do Brasil (Paraná e Santa Catarina). Tese de Doutorado em Antropologia Social, Universidade de São Paulo, São Paulo.

1988. Arqueologia brasileira - algumas considerações. Boletim do Museu Paraense Emílio Goeldi, antropologia, 4(2): 200-5.

1989. Teorias de Determinismo Ecológico na Amazônia: um caso de marginalidade da comunidade cientifica nacional. In: Neves, W. A. (org.), Biologia e Ecologia Humana na Amazônia: avaliação e perspectivas, pp. 59-76. Museu Paraense Emílio Goeld/SCT/CNPq, Belém.

Neves, W. et al. 1996 Cranial morphological variation and the colonization of the New World: towards a Four Migration Model. American Journal of Physical Anthropology, 22.

Neves, W. A. e Blum, M. 1999 Afinidades biológicas entre populacõoes pré-históricas do centro-sul brasileiro: uma análise multivariada. Fronteiras, 2(4): $143-69$.

Nimuendajú, C. 1981 Mapa Etno-Histórico. IBGE, Rio de Janeiro.

. 1987. As lendas de criação e destruição do mundo como fundamentos da religião dos ApapocuvaGuarani. Hucitec/Edusp, São Paulo.

Noelli, F. S. 1993 Sem Tekohá não há Tekó (em busca de um modelo etnoarqueológico da subsistência e da aldeia Guarani aplicado a uma área de domínio no delta do Jacuí-RS). Dissertação de Mestrado em História, Pontifícia 
Universidade Católica do Rio Grande do Sul, Porto Alegre.

1994 El Guaraní agricultor. Acción, 177: 17-23.

. 1996a As hipóteses sobre o centro de origem e as rotas de expansão dos Tupi. Revista de Antropolo

gia, 39(2): 7-53.

1996b Resposta Eduardo Viveiros de Castro e Greg Urban. Revista de Antropologia, 39(2): 100-18.

1996c Os Jê do Brasil meridional e a antigüidade da agricultura: elementos da Lingǘstica, Arqueolo

gia e Etnografia. Estudos Ibero-Americanos, 22(1): 13-26.

1998 The Tupi: explaining origin and expansion in terms of Archaeology and Historical Linguistics.

Antiquity, 72(277): 648-63.

. 1999a Repensando os rótulos e a História dos Jê no Sul do Brasil a partir de uma interpretação

interdisciplinar. In: Funari, P. P.; Neves, E. G. e Podgorny, I. (orgs.), Teoria Arqueológica na América do Sul.

MAE/USP, São Paulo.

. 1999b Aportes históricos e etnológicos para o reconhecimento da classificação Guarani de comunidades vegetais no século XVII. Fronteiras, 2(4): 275 - 96.

Noelli, F. S. e Dias, A. S. 1995 Complementos históricos ao estudo funcional da indústria lítica Guarani. Revista do CEPA, 19(22): 7-32.

Noelli, F. S. e Soares, A. 1997a Para uma História das epidemias entre os Guarani. Diálogos, 1: 165-78.

Noelli, F. S. e Soares, A. 1997b Efeitos da conquista européia na terminologia e organização social Guarani.

Cadernos de METEP, 8: 383-97.

Noelli, F. S e Brochado, J. P. 19980 cauim e as beberagens dos Guarani e Tupinambá: equipamentos, técnicas de preparação e consumo. Revista do Museu de Arqueologia e Etnologia, 8: 117-28.

Noelli, F. S. et al. 1996 Pari: armadilhas de pesca no Sul do Brasil e a Arqueologia. Anais da VIII Reunião Científica da Sociedade de Arqueologia Brasileira, 1 (2): 435-46.

Noelli, F. S. (org.) et al. 1998 Bibliografia Kaingang: referências sobre um povo Jê do Sul do Brasil. Editora da Universidade Estadual de Londrina, Londrina.

Noelli, F. S. et al. 1999 Primeiras análises sobre a funcionalidade e a freqüência da cerâmica de um sítio arqueológico Guarani da lagoa Xambrê - Paraná. Revista do CEPA, 23(30) (no prelo).

Noelli, F. S. et al. 1999 Espectroscopia Mössbauer da cerâmica arqueológica Guarani. Trabalho apresentado no VI Seminário de Pesquisa em História. Brasil 500 anos de(s)encontros, Maringá.

Pallestrini, L. 1968-69 0 sítio arqueológico Jango Luís. Revista do Museu Paulista, n.s., 18: 25-56.

. 1975. Interpretação das estruturas arqueológicas em sítios do Estado de São Paulo. Coleção do Museu Paulista, Série Arqueologia, 1. São Paulo. pp. 1-208.

Pallestrini, L. e Chiara, W. 1978 Indústria lítica de Camargo 76. Município de Pirajú, Estado de São Paulo. Coleção do Museu Paulista, Série Ensaios, 2. São Paulo. pp. 83-122.

Piazza, W. 1969 A área arqueológica dos "campos de Lages". Pronapa, 3. Publicações Avulsas do Museu Paraense Emílio Goeldi, 13: 63-74.

Ploetz, H. e Métraux, A. 1930 La civilisation matérielle et la vie sociele et religieuse des indiens Zè du Brésil méridional. Revista del Instituto de Etnología de la Universidad Nacional de Tucumán, 1: 107-238.

Politis, G. 1996 Nukak. Instituto Amazónico de Investigaciones Cientificas, Bogotá.

Prezia, B. A. G. 1997 Os indígenas do planalto paulista. Etnônimos e grupos indígenas nos relatos dos viajantes, cronistas e missionários dos séculos XVI e XVII. Dissertação de Mestrado em Lingüistica, Universidade de São Paulo, São Paulo.

Pronapa. 1970 Brazilian archeology in 1968: An interim report on the National Program of Archeology Research Pronapa. American Antiquity, 35(1): 1-23.

Reff, D. T. 1985 Disease, depopulation and culture change in Northwestern New Spain, 1518-1764. University of Utah Press, Salt Lake City.

Reis, J. 1997 Para uma Arqueologia dos buracos de bugre: do sintetizar, do problematizar, do propor. Dissertação de Mestrado em Arqueologia, Pontifícia Universidade Católica do Rio Grande do Sul, Porto Alegre.

Reis, M. J. 1980 A problemática arqueológica das estruturas subterrâneas no Planalto catarinense. Dissertação de Mestrado em Antropologia Social, Universidade de São Paulo, São Paulo.

Ribeiro, P. A. M. 1974 Primeiras datações pelo método C 14 para o vale do rio Caí, Rio Grande do Sul. Revista do CEPA, 1: 16-22.

. 1980 Casas subterrâneas do Planalto meridional, município de Santa Cruz do Sul, Brasil. Revista do 
CEPA, 9: 1-52.

1983 Sítios arqueológicos numa microrregião alagadiça na Depressão Central do Rio Grande do Sul.

Revista do CEPA, 10(12): 1-121.

1991 Arqueologia do vale do rio Pardo, Rio Grande do Sul, Brasil. Revista do CEPA, 18(21): 1-184.

1995 Arqueologia do vale do rio Pardo, Rio Grande do Sul, Brasil. Biblos, 7: 9-87

. 1999a Os mais antigos caçadores-coletores do Sul do Brasil. In: Tenório, M. C. (org.), Pré-História da

Terra Brasilis, pp. 75-88. Editora UFRJ, Rio de Janeiro.

Ribeiro, P. A. M. e Ribeiro, C. T. 1999 Escavações Arqueológicas no sítio RS/TQ/58, Montenegro, RS, Brasil. Editora da FURG, Rio Grande.

Ribeiro, P. A. M. e Ribeiro, C. T. 1985 Levantamentos arqueológicos no município de Esmeralda, RS, Brasil. Revista do CEPA, 12(14): 50-105.

Ribeiro, P. A. M. et al. 1986 Levantamentos arqueológicos no alto vale dos rios Camaquã e Irapuã, RS, Brasil. Revista do CEPA, 13(15): 41-70.

Ribeiro, P. A. M. et al. 1989 Levantamentos arqueológicos na encosta do planalto, entre o vale dos rios Taquari e Caí. Revista do CEPA, 16 (19): 135-51.

Rodrigues, A. 1964 A classificação do tronco lingüístico Tupi. Revista de Antropologia, 12: 99-104.

1985 Relações internas na família lingüística Tupi-guarani. Revista de Antropologia, 7-28: 33-53.

1986 Línguas Brasileiras. Loyola, São Paulo.

Rodriguez, J. A. 1996 Investigaciones arqueológicas en Yacyretá (Corrientes - Argentina). Anales de las Jornadas de Antropologia de la Cuenca del Plata, v. 3. Universidad Nacional de Rosário, Rosário.

Rogge, J. 1996 Adaptação na floresta subtropical: a tradição Tupiguarani no médio rio Jacuí e rio Pardo. Arqueologia do Rio Grande do Sul, Documentos, 6. Instituto Anchietano de Pesquisas, São Leopoldo.

Roosevelt, A. C. 1991 a Determinismo ecológico na interpretação do desenvolvimento social indígena da Amazônia. In: Neves, W. A. (org.), Origens, adaptações e diversidade biológica do homem nativo da Amazônia, pp. 103-41. $\mathrm{SCT} / \mathrm{CNPq} /$ Museu Paraense Emílio Goeldi, Belém.

.1991b Moundbuilders of the Amazon. Geophysical Archaeology on Marajo Island, Brazil. Academic Press, New York.

1995 Early pottery in the Amazon: twenty years of scholarly obscurity. In. Barnett, W. K. e Hoopes, J. (eds.), The emergence of pottery: technology and innovation in ancient societies, pp. 115-31. Smithsonian Institution Press, Washington.

Rütschilng, A. L. 1989 Pesquisas arqueológicas no baixo Camaquã. Arqueologia do Rio Grande do Sul, Documentos, 3. Instituto Anchietano de Pesquisas, São Leopoldo.

Salzano, F. M. e Sutton, H. 1965 E. Haptoglobin and transferin types of indians from Santa Catarina. American Journal of Human Genetics, 17 (3): 280-9.

Salzano, F. M. e Callegari-Jacques, S. 1988 South American Indians: a case study in evolution. Clarendon Press, Oxford.

Salzano, F. M. e Callegari-Jacques, S. 19910 índio da Amazônia: uma abordagem microevolucionária. In: Neves, W. (ed.), Origens, adaptações e diversidade biológica do homem nativo da Amazônia, pp. 39-53. SCT/CNPq/MEPG, Belém.

Santos, S. C. 1973 Índios e Brancos no Sul do Brasil - a dramática experiência dos Xokléng. Edeme, Florianópolis.

Schmitz, P. I. (coord.). 1967 Arqueologia no Rio Grande do Sul. Pesquisas, antropologia, 16: 47-78.

1969 Algumas datas de carbono 14 de casas subterrâneas no planalto do Rio Grande do Sul.

Pesquisas, antropologia, 20: 163-7.

. 1972 Cronologia de las culturas del sudeste de Rio Grande do Sul, Brasil. Antecedentes y Anales del I

Congreso Nacional de Arqueología. II Encuentro de Arqueología del Interior, pp. 105-17.

. 1976. Sítios de pesca lacustre em Rio Grande, RS, Brasil. Tese de Livre Docência, Pontifícia

Universidade Católica do Rio Grande do Sul, Porto Alegre.

1978 Industrias líticas en el sur de Brasil. Estudos Leopoldenses, 14(47): 103-32.

. 1987 Prehistoric hunters and gatherers of Brazil. Journal of World Prehistory, 1 (1): 53-126.

. 1988 As tradições ceramistas do planalto sul-brasileiro. Arqueologia do Rio Grande do Sul, Documen-

tos, 2: 74-130.

1991 Áreas arqueológicas do litoral e do planalto do Brasil. Revista do Museu de Arqueologia e

Etnologia, 1: 3-20.

1995 Acampamento litorâneo em Içara, SC. Um exercício de padrão de assentamento. Clío, arqueologia, 11 (1): 99-118. 
1999. 0 Guarani: História e Pré-História. In: Tenório, M. C. (org.), Pré-História da Terra Brasilis, pp. 285-92. Editora UFRJ, Rio de Janeiro.

Schmitz, P. I. e Brochado, J. P. 1972 Datos para uma secuencia cultural del Estado de Rio Grande do Sul, Brasil.Gabinete de Arqueologia, 2. Universidade Federal do Rio Grande do Sul, Porto Alegre.

Schmitz, P. I. e Brochado, J. P. 1981b Arqueología de Rio Grande do Sul, Brasil. Estudos Leopoldenses, 18(64): 161-84.

Schwarcz, L. 19930 espetáculo das raças. Companhia das Letras, São Paulo.

Sempé, M. C. e Caggiano, M. A. 1995 Las culturas agroalfareras del Alto Uruguay (Misiones), Argentina. Revista do Museu de Arqueologia e Etnologia, 5: 27-38.

Silva, C. 1998 Sobreviventes do extermínio: uma etnografia das narrativas e lembranças da sociedade Xetá. Dissertação de Mestrado em Antropologia Social, Universidade Federal de Santa Catarina, Florianópolis.

Silva, F. A. s.d.. As cerâmicas dos Jê do Sul do Brasil e os seus estilos tecnológicos: elementos para uma etnoarqueologia Kaingang e Xokleng. Revista do (EPA (no prelo).

Silva, F. A. e Noelli, F. S. 1996a A ocupação do espaço na Terra Indígena Apucarana - Paraná: elementos para uma reflexão interdisciplinar. Revista do CEPA, 20(24): 27-36.

Silva, F. A e Noelli, F. S. 1996b Para uma síntese dos Jê do Sul: igualdades, diferenças e dúvidas para a Etnografia, Etno-História e Arqueologia. Estudos Ibero-Americanos, 22(1): 5-13.

Silva, S. B. 19880 sítio arqueológico da Praia da Tapera: um assentamento Itararé e Tupiguarani. Dissertação de Mestrado em Antropologia, Universidade Federal do Rio Grande do Sul, Porto Alegre.

Simões, M. 1972 Índices das fases arqueológicas brasileiras, 1950-1971. Publicações Avulsas do Museu Paraense Emílio Goeldi, 18. Museu Paraense Emílio Goeldi, Belém.

Smithsonian. Radiocarbon list. Smithsonian Institution, Washington.

Soares, A. L. 1997 Guarani. Organização Social e Arqueologia. EDIPUCRS, Porto Alegre.

Tamanini, E. 1995 Museu Arqueológico de Sambaqui: um olhar necessário. Dissertação de Mestrado em Educação, Universidade Estadual de Campinas, Campinas.

Tommasino, K. et al. s.d. Bibliografia Xokleng: referências sobre um povo Jê do Sul do Brasil. Manuscrito inédito.

Tommasino, K. 1995 A História Kaingáng da bacia do Tibagi: uma sociedade Jê meridional em movimento. Tese de Doutorado em Antropologia Social, Universidade de São Paulo, São Paulo.

Trigger, B. 1989 A History of archaeological thougth. Cambridge University Press, Cambridge.

Urban, G. 1978 A model of Shokleng social reality. Tese de Doutorado em Antropologia, University of Chicago, Chicago. 1992 A História da cultura brasileira segundo as línguas nativas. In: Cunha, M. C. (org.), História dos índios no Brasil, pp. 87-102. Companhia das Letras/Fapesp/SMC, São Paulo.

Veiga, J. 1994. Organização social e cosmovisão Kaingang: uma introdução ao parentesco, casamento e nominação em uma sociedade Jê meridional. Dissertação de Mestrado em Antropologia, Universidade Estadual de Campinas, Campinas.

Vialou, A. V. 1980 Tecno-tipologia das indústrias líticas do sítio Almeida em seu quadro natural, arqueo-etnológico e regional. Museu Paulista/Instituto de Pré-História, São Paulo. 1983-84 Brito: o mais antigo sítio arqueológico do Paranapanema, Estado de São Paulo. Revista do Museu Paulista, n. s., 29: 9-21.

Viveiros de Castro, E. B. 1986. Araweté: Os deuses canibais. Jorge Zahar/ Anpocs, Rio de Janeiro. 1996 Comentário ao artigo de Francisco Silva Noelli. Revista de Antropologia, 39(2): 55-60.

Von den Steinen, K. 1894 Unter den Naturvölkern Central Brasiliens. Dietrich Reimer, Berlin.

Watts, S. 1997 Epidemics and History. Yale University Press, New Haven.

Wiesemann, U. 1978 Os dialetos da língua Kaingáng e Xokléng. Arquivos de Anatomia e Antropologia, 3: 197-217. Willey, G. e Sabloff, J. 1980 A History of American Archaeology. $2^{\text {nd }}$ ed. Freeman, San Francisco. 